
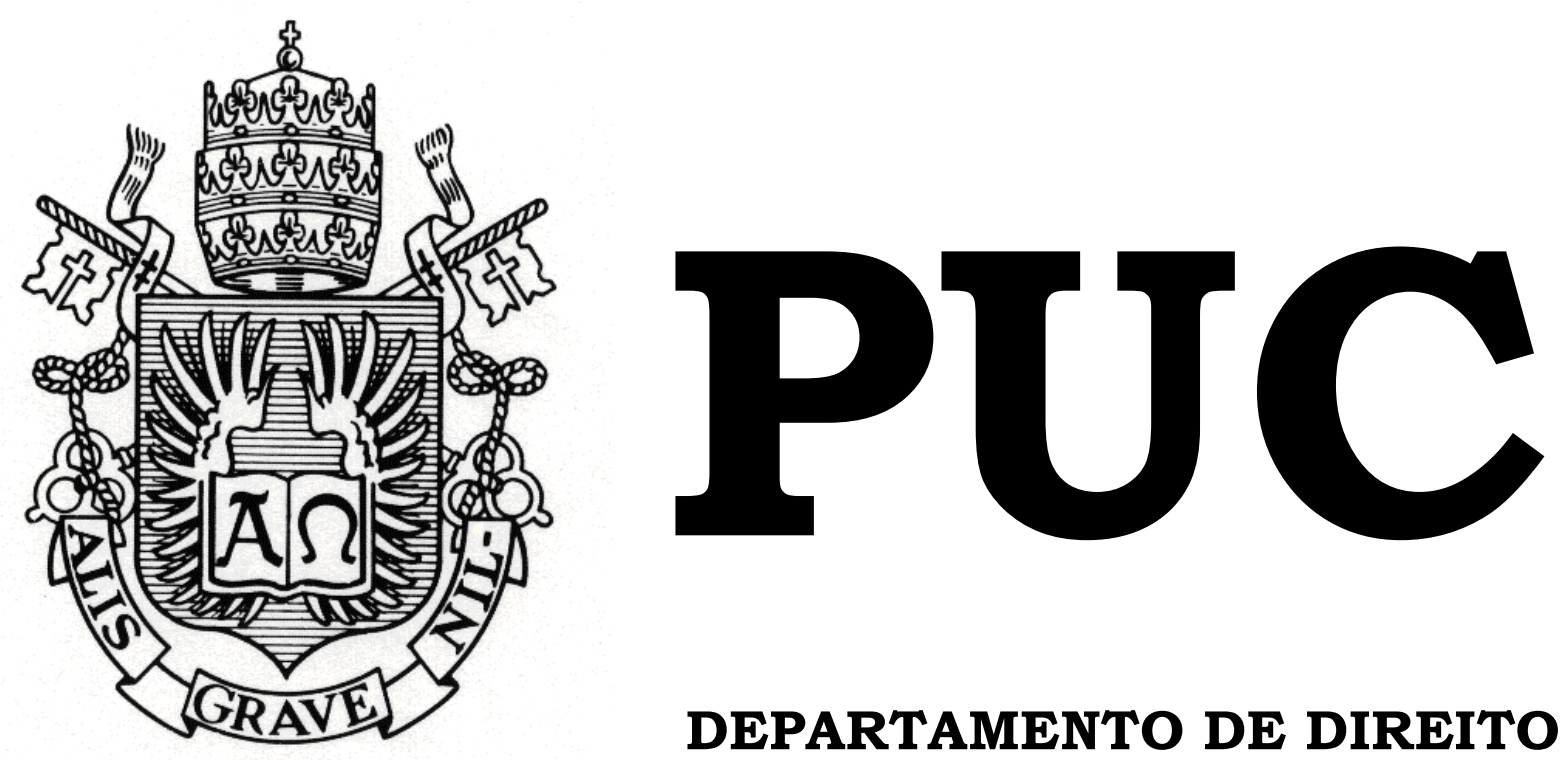

\title{
A AUTONOMIA DA VONTADE DA CRIANÇA E DO ADOLESCENTE
}

\author{
por \\ MANOELA MANSUR COELHO DE ALMEIDA \\ Orientadora: INÊS ALEGRIA ROCUMBACK
}

2018.1

PONTIFÍCIA UNIVERSIDADE CATÓLICA DO RIO DE JANEIRO

RUA MARQUÊS DE SÃO VICENTE, 225 - CEP 22453-900

RIO DE JANEIRO - BRASIL 


\title{
A AUTONOMIA DA VONTADE DA CRIANÇA E DO ADOLESCENTE
}

\author{
por
}

\section{MANOELA MANSUR COELHO DE ALMEIDA}

\begin{abstract}
Monografia apresentada ao Departamento de Direito da Pontificia Universidade Católica do Rio de Janeiro (PUC-Rio) como requisito parcial para a obtenção do Título de Bacharel em Direito.
\end{abstract}

Orientadora: Inês Alegria Rocumback 


\section{AGRADECIMENTOS}

Não há como iniciar qualquer forma de agradecimento, sem mencionar os meus pais, meus maiores exemplos. Obrigada por terem me formado como ser humano, por me darem a opção de escolha sempre que possível, por todo o amor, por todo o cuidado, por toda liberdade e, principalmente, obrigada por serem exatamente como vocês são, o motivo do maior orgulho da minha vida.

Obrigada Marcela, por ser a melhor irmã que eu poderia ter. Obrigada especialmente por me dar a certeza de ser minha eterna companheira e por sermos mais do que só um sangue ou uma marca na pele.

Ao meu querido namorado por toda paciência e compreensão depreendidos nessa fase. Sem todo seu eterno incentivo e, principalmente, sem sua incomparável companhia essa etapa não teria sido concluída de forma tão feliz.

Agradeço aos meus amigos, membros da família que eu escolhi que torcem e vibram por mim a cada conquista, como se fossem as deles.

À minha orientadora, Inês, por todo o carinho e incentivo dado e pelos ensinamentos passados, dentro e fora de sala de aula. Esse trabalho é resultado de um esforço conjunto.

Agradeço a Universidade que me formou como ser humano e como operadora do Direito. Encontrei no famoso campus da PUC uma segunda casa.

São muitas as pessoas as quais devo agradecer, afinal, não somos capazes de fazer nada sozinhos. Há e sempre houve muita coisa por trás de cada gesto, cada atitude tomada. 
Mas existe um lugar amado no qual meu agradecimento, nessa fase da vida, é especial. Obrigada Paulo Lins e Silva Advogados e Consultores de Família. Não poderia ser mais sincera ao dizer que escolhi o melhor lugar do mundo para encerrar essa etapa.

Todos, absolutamente todos os estudantes de direito do Brasil, quiçá do mundo, deveriam ter a honra e o prazer de compartilharem as experiências das quais eu compartilhei ao lado das pessoas que ali trabalham.

Eu poderia tecer amplos elogios aos ensinamentos que me foram dados na seara jurídica. Afinal, trabalhar com o direito de família é trabalhar em uma zona sensível, recheada de intimidade e afeto e, ao mesmo tempo, com uma ampla dosagem técnica que requer uma habilidade ímpar de seus instrumentadores. Não restam dúvidas que um dos maiores, se não o maior, escritório destinado exclusivamente a esta área no Brasil desempenha essa função com maestria.

Por tal razão, me sinto confortável em dispensar, neste momento, os aplausos merecidos a esta equipe jurídica com a qual eu tive a honra de trabalhar, ate porque não seria possível expressá-los em meras palavras. Contudo, não me encontro igualmente confortável em dispensar meus mais sinceros agradecimentos as pessoas que ali trabalham, digo pessoas e não profissionais porque conviver por um ano e meio naquele ambiente me fez fazer amigos e não colegas de trabalho.

Trabalhar na Rua Visconde de Pirajá, 351 me fez ganhar um segundo pai, uma segunda irmã, um novo melhor amigo, mais um tio chato com piadas bobas, mas extremamente necessário à harmonia de uma família, uma prima com os mesmos vícios que os meus. Trabalhar com cada uma das vinte pessoas com quem eu trabalhei, significa ganhar uma família.

Eu não poderia agradecer mais por ter convivido com pessoas tão humanas, que exalam cada uma a sua maneira, valores tão honrosos. Um 
dia no complexo 924 significa anos de aula de bom humor, de companheirismo, de carinho, de cuidado e, principalmente, de ajuda mútua. Não houve um só dia que alguém abrisse aquela porta em um dia ruim e, não saísse com um sorriso estampado no rosto.

Apesar de todas as dificuldades que ali possam ser encaradas, não há como não ser alegre naquele espaço. Obrigada por me ensinarem sobre vida, antes mesmo de me ensinarem sobre direito. Trabalhar com vocês, é escolher ser feliz todo dia e nenhuma forma de agradecer vai ser suficiente.

Por fim, expresso minha eterna gratidão ao meu querido "chefe" por toda confiança e amizade depositada ao longo desse tempo. Sem toda a sua generosidade esse trabalho não teria sido concluído de forma tão leve. 


\section{RESUMO}

ALMEIDA, Manoela Mansur Coelho. A AUTONOMIA DA VONTADE DA CRIANÇA E DO ADOLESCENTE. Rio de Janeiro, 2018. 101 p. Monografia de final de curso - Departamento de Direito, Pontifícia Universidade Católica do Rio de Janeiro.

O presente trabalho visa impulsionar uma reflexão bem como uma discussão criteriosa e cautelosa acerca dos princípios e institutos presentes no ordenamento jurídico brasileiro que cercam e protegem as crianças e os adolescentes, restringindo as suas respectivas autonomias.

Com o fito de cumprir esse objetivo com clareza, analisar-se-ão as peculiaridades intrínsecas ao instituto da incapacidade, do princípio do melhor interesse da criança e da relação entre os pequenos e suas famílias como predominantes tomadoras de decisão.

Ademais, dando sequência as mencionadas análises, se estudará brevemente a relação existente entre o Estado e a família, como protetora dos menores de idade. Logo, para que o referido estudo seja realizado com clareza, será feito um breve resumo acerca da constitucionalização da família brasileira e suas consequências para os infantes.

Ao final, abordar-se-ão problemáticas resultantes das limitações da autonomia da vontade da criança e do adolescente no seio dos direitos da personalidade, bem como será proposta um novo olhar acerca de tantos conflitos e paradoxos que acabam por surgir durante todas as análises. Para tanto, o presente trabalho contará com exposição doutrinária e jurisprudencial.

Palavras chave: Criança. Adolescente. Autonomia. Incapacidade. Família. Estado. Direitos da Personalidade. Liberdade. Princípio do melhor interesse. Dignidade. 
INTRODUÇÃ O.......................................................................................9

Capítulo I - A Autonomia da criança e do adolescente e suas limitações.

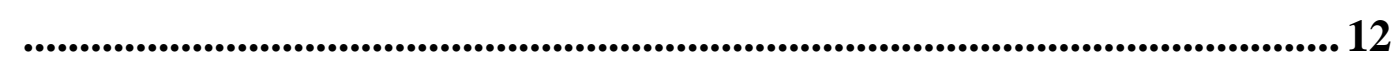

1.1 Autonomia da vontade: conceito e evolução histórica. ........................... 12

1.2 Crianças e Adolescentes: definição, diferenças e legislação

pertinente

1.2.1 Um olhar para fora: reconhecimento e evolução dos direitos das crianças e dos adolescentes em caráter global....................................... 18

1.2.2 Um olhar para dentro: evolução normativa brasileira quanto às crianças e aos adolescentes.................................................................. 19

1.3 Incapacidade e menoridade: conceitos indissociáveis............................2

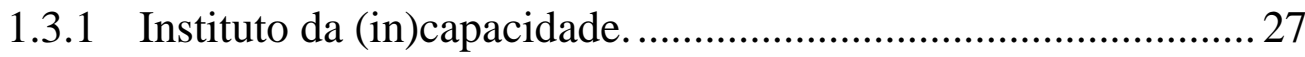

1.3.1.1 Absolutamente incapazes............................................... 28

1.3.1.2 Relativamente incapazes................................................ 28

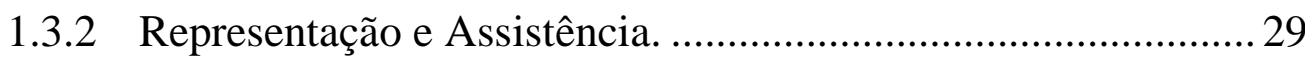

1.3.3 A sensível questão do discernimento dos pequenos para imposição de sua incapacidade e a teoria do menor maduro................... 31

$1.4 \mathrm{O}$ poder familiar entendido como uma forma de limitação à autonomia

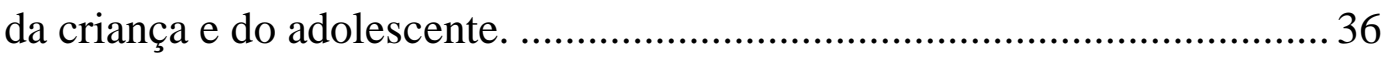
1.5 Aparato legislativo e jurídico em prol da proteção da criança e do adolescente e suas contradições......................................................................... 39

Capítulo II - Triangulação visando a proteção e os interesses das crianças e dos adolescentes: Estado, família e autonomia........................ 44

2.1 Constitucionalização da família brasileira: a recepção de princípios constitucionais na relação existente entre os membros da família............... 44

2.1.1 Família-instrumento e família democrática. ............................... 46

2.2 Intervencionismo Estatal versus Autoridade Parental. ........................... 48 
2.2.1 Visitação avoenga: previsão legislativa objetivando a concretização do direito ao convívio familiar da criança e do adolescente.

2.2.2 Guarda compartilhada: intervenção estatal tornando a opção como regra. 56

2.3 Autoridade parental versus a autonomia da criança e do adolescente: o dever de cuidado em choque com a função emancipatória. 62 $2.4 \mathrm{O}$ instituto da emancipação: atribuição da capacidade civil aos menores de 18 anos. 67

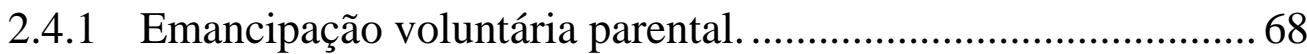

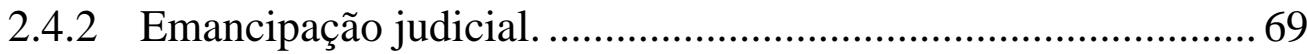

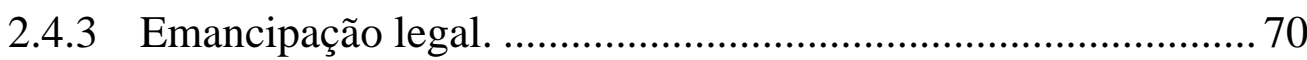

Capítulo III - Decisões subjetivas existenciais e a preservação da autonomia da criança e do adolescente. ......................................................... 73

3.1 Direitos da personalidade da criança e do adolescente: respeito, exercício e desenvolvimento.

3.2 Pontos de partida: questões objetivas dentro das decisões subjetivas

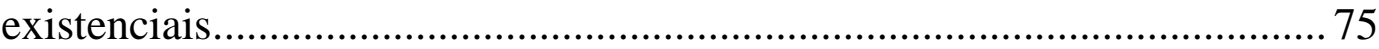

3.2.1 Reversibilidade ou Irreversibilidade das decisões..................... 77

3.2.2 Adiabilidade ou inadiabilidade das decisões. ............................. 77

3.2.3 Combinações cabíveis no caso concreto..................................... 79

3.3 Desdobramento dos direitos da personalidade: direito ao nome. .......... 81

3.4 Direito a privacidade: confidencialidade existente na relação entre o

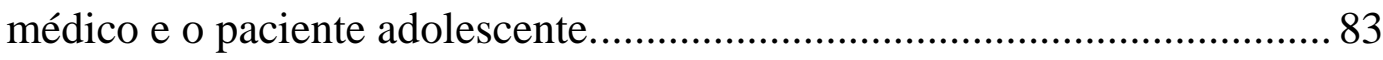

CONCLUSÃO

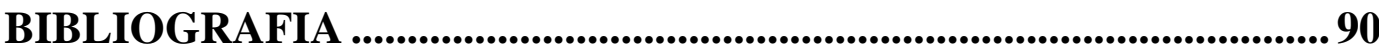




\section{LISTA DE ABREVIAÇÕES}

$\begin{array}{ll}\text { Art. }- & \text { Artigo } \\ \text { CRFB }- & \text { Constituição da República Federativa do Brasil } \\ \text { CLT }- & \text { Consolidação das Leis Trabalhistas } \\ \text { CPC }- & \text { Código de Processo Civil } \\ \text { CPP }- & \text { Código de Processo Penal } \\ \text { Des. }- & \text { Desembargador } \\ \text { ECA }- & \text { Estatuto da Criança e do Adolescente } \\ \text { p. }- & \text { página } \\ \text { STF }- & \text { Supremo Tribunal Federal } \\ \text { STJ }- & \text { Superior Tribunal de Justiça }\end{array}$




\section{INTRODUÇÃO}

Os estudos, pesquisas e análises envolvendo as crianças e os adolescentes no ordenamento jurídico brasileiro costumam enaltecer os avanços obtidos em relação a estes sujeitos. É bem verdade que com a evolução social, as crianças e os adolescentes passaram a não só serem vistos como sujeitos de direitos, como passaram a ser sujeitos de extrema proteção, chegando a ocupar o centro das atenções da família.

No decorrer do século XX, diversas legislações surgiram com o fito de proteger os menores de idade, os garantindo um desenvolvimento sadio tanto físico, como moral e psicológico. No ordenamento jurídico brasileiro, tivemos inovações extremamente significativas que vigoram até os dias atuais, como por exemplo, o Estatuto da Criança e do Adolescente, conhecido como ECA.

Ademais, a Constituição de 1988 significou um marco de mudanças positivas tanto para os pequenos como para o seio familiar. Em decorrência desses novos acontecimentos legislativos, instituiu-se no ordenamento jurídico brasileiro a ideia de que os menores de idade, por encontrarem-se em fase de desenvolvimento e formação, são sujeitos altamente vulneráveis, carecedores de total proteção, surgindo então, o princípio do melhor interesse da criança.

Sob esta égide, o processo de constitucionalização da família brasileira, que será objeto de breve análise no Capítulo 2 deste estudo, foi responsável pela inserção desse, e de diversos outros princípios no meio familiar, fazendo com que o conhecido pátrio poder se transformasse em poder familiar, diferentemente daquele eis que o filho não é visto mais como objeto de submissão dos pais.

Ou seja, as ações, decisões e demais atitudes que refletirem nas crianças e nos adolescentes pertencentes a família, deverão ser tomadas em prol dos pequenos. Para que isso se tornasse uma realidade, ou ao menos houvesse uma aproximação do ideal, o Estado passou a intervir pontualmente nas decisões e escolhas tomadas pelos responsáveis dos infantes, bem como passou a regular certas situações que acabavam tendo seu desfecho no poder judiciário. 
Diante de tamanha proteção, assumiu-se, sem questionamentos, uma ausência de discernimento por parte das crianças e dos adolescentes que as impossibilitariam de tomarem certas decisões relacionadas as suas próprias vidas e, garantirem assim, seus interesses.

Deste modo, instituiu-se no ordenamento jurídico o regime de incapacidades, expressado no artigo 3 e 4 do Código Civil Brasileiro, objeto de estudo do Capítulo 1, onde determinou-se que os menores de idade seriam, absolutamente incapazes (até os 16 anos) ou relativamente incapazes (os maiores de 16 anos e menores de 18 anos) para garantirem por si só seus interesses através de suas escolhas.

Ao serem embarcados nesse regime de incapacidades, formulado por diversas especulações acerca da suposta ausência de discernimento, as crianças e os adolescentes ficaram a mercê de terceiros que, podem ou não estar de boa-fé, para seguirem com o caminho de suas próprias vidas.

Diante dessa reflexão, inúmeras situações problemáticas passam a surgir, principalmente quando se trata de questões íntimas, de cunho personalíssimo. Afinal, terceiros tomarem decisões acerca do ser de outrem pode gerar danos irreparáveis, independentemente da intenção depositada. Sobre o tema, o Capítulo 3 deste estudo, propõe uma nova ótica para a questão.

Ao invés de se conceber, sem questionamentos, a noção de que as crianças e os adolescentes são absolutamente ou relativamente incapazes para tomarem certas decisões acerca de suas vidas, dependendo completamente de opiniões e decisões de terceiros, propõe-se uma análise profunda acerca do discernimento havido pelos pequenos naquele momento específico que carece de um decisum.

Com o auxílio de equipes interdisciplinares e, principalmente, com a ajuda dos familiares, será percebido o momento que o menor de idade possui discernimento e noção para se posicionar perante certas situações, obtendo consequentemente, cada vez mais liberdade e autonomia. Afinal, o grau de autonomia dos pequenos se altera e, em regra, aumenta em cada etapa ultrapassada de sua vida. 
Não se pode, contudo, anular as benesses trazidas pelos princípios de tutela integral e do melhor interesse da criança, afinal, não se pode olvidar que esta fase da vida é, sim, de fato, repleta de incertezas e vulnerabilidade. Diante disso, o segundo Capítulo deste estudo é voltado para a atuação tanto da família como do Estado na vida das crianças e dos adolescentes, que se mostram essenciais.

Posto isso, o presente trabalho visa ao longo de seus capítulos subsequentes, analisar as nuances e peculiaridades envolvidas no sistema jurídico brasileiro quando este é voltado para a restrição da autonomia da vontade das crianças e os adolescentes. Em adição, propõe uma nova reflexão e um novo diálogo objetivando garantir um sistema mais flexível e realista aos menores de 18 anos, para que os mesmos possam ter a real garantia de um desenvolvimento sadio e, assim, da efetivação completa da dignidade da pessoa humana, que possui, por sua vez, em um de seus pilares, a liberdade. 


\section{Capítulo I - A Autonomia da criança e do adolescente e suas limitações.}

\subsection{Autonomia da vontade: conceito e evolução histórica.}

Para que se compreenda a "autonomia da vontade" com exatidão, importante trazer a baila sua origem história. Esta possui seu nascedouro no direito contratual e prolifera-se para as demais áreas do direito devido o seu significado extremamente relevante e facilmente adequável nas relações interpessoais e entre pessoas e Estado. Posto isso, não há como introduzir tal assunto sem que se comente brevemente a respeito das relações contratuais, as quais não são objeto do nosso estudo.

Indubitavelmente, um dos princípios de maior relevância de nosso ordenamento jurídico, por muitos apontado como um dos pilares do direito privado, é o princípio da autonomia da vontade. O vocábulo autonomia deriva da conjunção de “auto”, que em grego quer dizer "próprio", "só por si”, "em si mesmo" com "nomos", também grego, que significa "regra". Assim, como enuncia JOSÉ ROBERTO DE CASTRO NEVES, “autonomia, portanto, consiste no poder de estabelecer as suas próprias regras " .

Com efeito, etimologicamente, autonomia, significa o poder de modelar por si - e não por imposição externa - as regras da própria conduta. É o poder de se autogovernar que revela um direito de tomada de decisões com liberdade e independência moral ou intelectual. É o contrário de heteronomia, que significa a sujeição a uma lei exterior ou à vontade de outrem. ${ }^{2}$

Vontade, por sua vez, originário do latim voluntate, em consonância com a definição dada pelo Dicionário Aurélio, é a faculdade de representar mentalmente um ato que pode ou não ser praticado em obediência a um impulso

\footnotetext{
${ }^{1}$ NEVES, José Roberto de Castro. Direito das Obrigações. Rio de Janeiro: GZ Editora, 2008, p.73.

${ }^{2}$ CABRAL, Érico de Pina. A 'autonomia" no direito privado, Revista de Direito Privado, v.19, Ano 5 (julho-setembro de 2004), (Org.) Nelson Nery Júnior e Rosa Maria de Andrade Nery, Ed. Revista dos Tribunais, p.85. O autor ainda esclarece que autonomia é a faculdade de traçar suas próprias normas de conduta, sem que seja submetido a imposições de ordem estranha, ou seja, rege-se através de um regramento próprio e interno ao passo que o heterônomo recebe do exterior as leis reguladoras de sua conduta.
} 
ou a motivos ditados pela razão. É sentimento que incita alguém a atingir o fim proposto por esta faculdade; aspiração, anseio; desejo.

Juridicamente, como leciona ECIO PERIN JÚNIOR:

a vontade revela a própria intenção, ou desejo em se fazer alguma coisa. Corresponde, pois, à deliberação, ou à resolução, intencionalmente tomada pela pessoa, a fim de que se tenha como consentimento na prática, ou na execução de um ato jurídico, de que se geram direitos, ou nascem obrigações ${ }^{3}$.

Vê-se, pois, que, para o Direito, a vontade reveste-se de importância fundamental, na medida em que se constitui um dos principais elementos do ato jurídico. Com efeito, a livre manifestação da vontade, destituída de qualquer vício ou defeito que a macule, tem o condão de criar, modificar ou extinguir relações jurídicas.

Segundo RAO, em sua clássica obra sobre atos jurídicos:

a vontade, manifestada ou declarada, possui no universo jurídico poderosa força criadora: é a vontade que através de fatos disciplinados pela norma, determina a atividade jurídica das pessoas e, em particular, o nascimento, a aquisição, o exercício, a modificação ou a extinção de direitos e correspondentes obrigações, acompanhando todos os momentos e todas as vicissitudes destas e daquelas 4 .

Nesse contexto, surge a autonomia da vontade como sendo "o princípio de direito privado pelo qual o agente tem a possibilidade de praticar um ato jurídico, determinando-lhe o conteúdo, a forma e os efeitos". 5

MARIA HELENA DINIZ conceitua o princípio da autonomia da vontade como "o poder de estipular livremente, como melhor lhes convier, mediante acordo de vontade, a disciplina de seus interesses, suscitando efeitos tutelados pela ordem jurídica" ${ }^{6}$ e, por seu turno, CLÓVIS DO COUTO E SILVA reafirma o conceito como a

possibilidade, embora não ilimitada, que possuem os particulares para resolver seus conflitos de interesses, criar, associações, efetuar o escambo dos bens e dinamizar,

\footnotetext{
${ }^{3}$ JÚNIOR, Ecio Perin. In: O Novo Código Civil Discutido por Juristas Brasileiros, (Org) Aparecido Hernani Ferreira, Bookseller Ed., $1^{\text {a }}$ ed., 2003, p.109.

${ }^{4}$ RAO, Vicente. Ato jurídico, Ed. Max Limonad, 1961, apud Ibid. p.111.

5 AMARAL, Francisco. A autonomia privada, apud Iacyr de Aguilar Vieira, A autonomia da vontade no Código Civil Brasileiro e no Código de Defesa do Consumidor, Revista dos Tribunais, ano 90, v.791 (setembro de 2001), Ed. RT, p.36.

${ }^{6}$ DINIZ, Maria Helena. Curso de Direito Civil Brasileiro: teoria das obrigações contratuais e extracontratuais. 27 ed. São Paulo: Saraiva, 2011.
} 
enfim, a vida em sociedade. Para a realização desses objetivos, as pessoas vinculam-se, e vinculam-se juridicamente, através de sua vontade. ${ }^{7}$

\section{Como nos alerta OTÁVIO LUIZ RODRIGUES JÚNIOR ${ }^{8}$,} tradicionalmente invoca-se IMMANUEL KANT como o precursor da expressão autonomia da vontade, a partir de sua Fundamentação da metafísica dos costumes, o que nos revela que, em verdade, o princípio da autonomia da vontade é a expressão de um sistema filosófico adaptado ao Direito.

Neste sentido é o posicionamento de IACYR DE AGUILAR VIEIRA que, citando GOUNOT, apontou alguns axiomas pelo mesmo resumidos e relativos a tal sistema adaptado:

edifício na base do social e jurídico se encontra o indivíduo, quer dizer, uma vontade livre. A liberdade faz do ser humano seu próprio mestre, o torna infinitamente respeitável e sagrado, o eleva à dignidade de fim em si mesmo. No sentido mais geral da palavra, o direito não é outra coisa senão esta liberdade inicial e soberana que pertence a todo homem. Da vontade livre tudo procede, a ela tudo converge ${ }^{\text {? }}$

É importante assinalar que tais concepções filosóficas, cujos respectivos fundamentos se sustentavam na liberdade e individualismo, explicam a evolução histórica do princípio da autonomia da vontade, pois as mesmas se consubstanciam no substrato teórico da Revolução Francesa, época em que o dogma da vontade atinge o seu ápice.

Com efeito, de aludido momento histórico, que objetivava barrar as arbitrariedades do absolutismo, decorre uma nova concepção da política, "que se

\footnotetext{
${ }^{7}$ COUTO E SILVA, Clóvis do. A obrigação como processo. São Paulo: Bushatsky, 1976.

8 JÚNIOR, Otávio Luiz Rodrigues.A doutrina do terceiro cúmplice: autonomia da vontade, o princípio 'res inter alios acta', função social do contrato e a interferência alheia na execução dos negócios jurídicos, In Revista dos Tribunais, ano 93, v.821, março de 2004, Ed. RT, p.82. Segundo o filósofo, "autonomia da vontade é aquela sua propriedade graças à qual ela é para si mesma a sua lei (independentemente da natureza dos objetos do querer). O princípio da autonomia é portanto: não escolher senão de modo a que as máximas da escolha estejam incluídas simultaneamente, no querer mesmo, como lei universal. Que esta regra prática seja um imperativo, quer dizer que a vontade de todo o ser racional esteja necessariamente ligada a ela como condição, é coisa que não pode demonstrar-se pela simples análise dos conceitos nela contidos, pois se trata de uma proposição sintética: teria que passar-se além do conhecimento dos objetos e entrar numa crítica do sujeito, isto é da razão prática pura; pois esta proposição sintética, que ordena apodicticamente, tem que poder reconhecer-se inteiramente a priori.

${ }^{9}$ COUTO E SILVA, Clóvis do. Op. cit., p.33.
} 
torna contratual ("o contrato social) e o contrato politiza-se em torno do princípio da autonomia da vontade, núcleo central das convenções"10.

Como assevera ÉRICO DE PINA CABRAL "a vontade torna-se a expressão da liberdade humana. Ninguém podia se obrigar senão por sua vontade livre e espontânea"11 e, citando LUIZ GUILHERME LOUREIRO, complementa:

é o reino do individualismo categórico: o direito não pode compelir ou impedir ninguém de contratar; a pessoa pode contratar com quem ela quiser e sobre o que ela pretender. Por outro lado, a seguridade contratual depende do direito: as obrigações livremente assumidas devem ser cumpridas, sob pena de sanção jurídica ${ }^{12}$.

De fato, como corolário da autonomia da vontade, surge a força obrigatória dos contratos, que encontra respaldo legal na clareza da regra estatuída pelo art.1134 do Código Civil Francês. E é justamente no cenário das relações obrigacionais, notadamente em sede contratual, que o princípio da autonomia da vontade se revela como o expoente da concepção individualista e liberal que ao tempo de sua elaboração imperava e que dominou o pensamento jurídico durante o século XIX e boa parte do século XX.

Ocorre que, passada a fase do esplendor individualista, os juristas notaram que a irrestrita liberdade no exercício das vontades ensejava, não raras vezes, situações de injustiça, ante a manifesta desigualdade entre os contratantes.

Por certo, como concluiu ÁLVARO ALMEIDA, "o culto pela liberdade desenfreada estava levando a consequências desastrosas, eis que outros valores humanos, tão fundamentais quanto à própria liberdade que se cultuava, estavam sendo subestimados"13.

Em assim sendo, a irrestrita autonomia da vontade foi cedendo espaço para novas concepções que mais se preocupavam com a concretização do valor justiça e, em sede contratual, isso se torna absolutamente perceptível com a

\footnotetext{
${ }^{10}$ CABRAL, Érico de Pina. A 'autonomia" no direito privado, Revista de Direito Privado, v.19, Ano 5 (julho-setembro de 2004), Coor. Nelson Nery Júnior e Rosa Maria de Andrade Nery, Ed. Revista dos Tribunais,p.87.

11 Ibid. p.87/88.

${ }^{12}$ LOUREIRO, Luiz Guilherme. Teoria geral dos contratos no novo código civil. Ed. Método, 2002, p.38.

${ }^{13}$ ALMEIDA, Álvaro Henrique Teixeira de. Apontamentos sobre a teoria da imprevisão, in Ciência Jurídica, ano XIV, volume 93, (maio/junho de 2000), RCJ Edições Jurídicas, p.37.
} 
mitigação do princípio da obrigatoriedade, consolidado na velha máxima pacta sunt servanda, na medida em que o ordenamento jurídico passou a admitir ingerência do estado-juiz nas relações contratuais, não só em prol do restabelecimento do equilíbrio econômico do contrato, mas também para assegurar a igualdade de forças dos contratantes.

Este novo cenário implica em imprimir ao princípio da autonomia da vontade novos contornos, mais compatíveis com os atuais princípios norteadores do direito privado, calcados na eticidade e solidariedade das relações intersubjetivas, não só as de natureza obrigacional, como também todas as demais.

Assim, se é fato que o princípio da autonomia da vontade teve seu nascedouro e apogeu em sede de relações contratuais, com a mitigação da ideologia individualista e liberal do século XIX, novo panorama jurídico exsurgiu a viabilizar a observância do princípio da autonomia da vontade em outras áreas do Direito.

Com efeito, em sede de Direito de Família, a nova roupagem da autonomia da vontade se faz presente, pois o poder absoluto dos pais, por exemplo, fincado exclusivamente em suas respectivas vontades, cede espaço para observância de outros princípios que visam maior proteção à prole, como aquele que exige observância do melhor interesse da criança em situações conflituosas, e para satisfação da dignidade da pessoa humana.

O melhor interesse do menor pode ser identificado segundo PIETRO PERLINGIERI "com a obtenção de uma autonomia pessoal e de juízo, que pode se concretizar na possibilidade de exprimir escolhas nos mais diversos setores" e o doutrinador complementa "desde que sejam salvaguardados a sua integridade psicofísica e o crescimento global de sua personalidade" ${ }^{14}$.

Neste novo cenário, os menores surgem como sujeitos de direitos e merecedores de terem suas vontades respeitadas e consideradas, vale dizer, a

\footnotetext{
${ }^{14}$ PERLINGIERI, Pietro. A doutrina do direito civil na legalidade constitucional. In: TEPEDINO, Gustavo (Org.). Direito civil contemporâneo: novos problemas à luz da legalidade constitucional. São Paulo: Atlas, 2008, p. 1003.
} 
autonomia da vontade das crianças e adolescentes ganha relevo e importância para solução justa quando em conflito os interesses dos mesmos, circunstância essa que, por si só, exterioriza a relevância jurídica do tema, a exigir maiores reflexões, consubstanciando-se o presente estudo em singela contribuição a tal reflexão.

Tendo isto posto, para que por fim adentre-se ao conteúdo merecedor deste estudo, passa-se a analisar quem é a criança e o adolescente no ordenamento jurídico brasileiro.

\subsection{Crianças e Adolescentes: definição, diferenças e legislação pertinente.}

Segundo a Convenção Internacional dos Direitos das Crianças de 1989, da qual o Brasil é signatário: "criança é todo ser humano menor de 18 anos". 15 Entretanto, em conformidade com o Estatuto da Criança e do Adolescente (Lei 8.069/90) crianças são os indivíduos compreendidos entre 0 (zero) a 12 (doze) anos incompletos, diferenciando-se dos adolescentes que, são pessoas com idade compreendida entre 12 (doze) e 18 (dezoito) anos de idade. Sendo certo, portanto, que o caráter diferenciador entre criança e adolescente está restrito ao aspecto etário.

Nos dias atuais, porém, fala-se além de crianças e adolescentes, em “jovens" referindo-se a indivíduos que tenham entre 15 (quinze) e 29 (vinte e nove) anos de idade. ${ }^{16}$ Objetivando interromper quaisquer eventuais conflitos possíveis entre o ECA e o Estatuto da Juventude (Lei 12.852/2013), este em seu artigo $1^{\circ}$, parágrafo $2^{\circ}$ determinou que aos menores de 18 anos prevaleceria às regras dispostas no Estatuto da Criança e do Adolescente. Os sujeitos do nosso estudo, por sua vez, estão compreendidos entre os tutelados pelo ECA, ou seja, menores de 18 (dezoito) anos de idade.

\footnotetext{
15 ALBERNAZ JÚNIOR, Victor Hugo.; FERREIRA, Paulo Roberto Vaz. Convenção sobre os direitos das crianças. São Paulo: Malheiros, 2011. p. 12

${ }^{16}$ Estatuto da Juventude - Lei 12.852/2013: art. 1, parágrafo $1^{\circ}$ : "para efeitos desta lei, são considerados jovens as pessoas com idade entre 15 (quinze) e 29 (vinte e nove) anos de idade".
} 


\subsubsection{Um olhar para fora: reconhecimento e evolução dos direitos das crianças e dos adolescentes em caráter global.}

A história mundial no que tange o reconhecimento das crianças e dos adolescentes como sujeitos de direitos e carecedores de proteção especial não foi sempre desenhada como nos moldes atuais. Isso quer dizer que as crianças e os adolescentes foram ser reconhecidos tal como são nos dias de hoje, pela legislação recente, sendo anteriormente considerados como indivíduos totalmente subjugados aos pais.

Na Era Romana, por exemplo, o poder paterno em relação aos filhos se dava de maneira irrestrita, inexistindo qualquer proteção voltada a assegurar a integridade física ou moral dos pequenos. Neste diapasão, MARIA REGINA DE AZAMBUJA assinala:

Em Roma (449 a.C), a Lei das XII Tábuas permitia ao pai matar o filho que nascesse disforme mediante julgamento de cinco vizinhos (Tábua Quarta, $\mathrm{n}^{\circ} 1$ ), sendo que o pai tinha sobre os filhos nascidos de casamento legítimo o direito de vida e de morte e o poder e vende-los (Tábua Quarta $\mathrm{n}^{\circ}$ 2). Em Roma e na Grécia Antiga, a mulher e os filhos não possuíam qualquer direito. ${ }^{17}$

Chega-se a dizer até, que em Roma não se contemplava a noção de infância, quiçá de sua proteção. Com o passar dos séculos, mais precisamente entre o século XVI e XVII, chegou-se a um avanço tímido e pouco louvável, no que diz respeito aos direitos desse grupo. Isso porque a legislação vigente na época entendeu que indivíduos após 7 (sete) anos de idade assumiam deveres e responsabilidades inerentes ao de adultos, enquanto os menores de 7 (sete) anos poderiam então ser poupados. ${ }^{18}$

Somente ao final do século XIX, início do século XX que a criança passou a ser reconhecida pelos ordenamentos jurídicos internacionais como sujeito de direitos e vista como centro do núcleo familiar, merecedora de carinho e afeto. Neste passo, NIVEIA BARROS destaca:

\footnotetext{
17 AZAMBUJA, Maria Regina Fay de. Violência sexual intrafamiliar: é possível proteger a Criança?; Revista Virtual de Textos e Contextos. São Paulo: vol. 01, n. 05, nov., 2006., p. 12.

18 ALBERTON, Maria Silveira. Violação da Infância. Crimes abomináveis: humilham, machucam torturam e matam!. São Paulo: AGE Ltda, 2005. p. 21
} 
Até o final do século XIX (...), a criança foi vista como um instrumento de poder e de domínio exclusivo da Igreja. Somente no início do século XX, a medicina, a psiquiatria, o direito e a pedagogia contribuem para a formação de uma nova mentalidade de atendimento à criança, abrindo espaços para uma concepção de reeducação, baseada não somente nas concepções religiosas, mas também científicas. ${ }^{19}$

Somente no ano de 1919 que houve um efetivo reconhecimento a respeito dos direitos das crianças em âmbito internacional com a criação do chamado Comitê de Proteção da Infância pela Liga das Nações, após a Primeira Guerra Mundial que acabou por deixar uma enorme quantidade de crianças e adolescentes órfãos. $^{20}$

E, somente em 1959 que se adotou a Declaração dos Direitos das Crianças. Foi em 1969 com a Conferência Interamericana de Direitos Humanos que se consolidou o direito de todas as crianças terem medidas de proteção tanto em âmbito familiar, como social e por parte do Estado, sob perspectiva de serem vulneráveis.

Por fim, teve-se como um marco mundial a Convenção Internacional sobre o Direito das Crianças, realizada em 1989 que serviu de inspiração para elaboração Estatuto da Criança e do Adolescente no Brasil no ano seguinte. Em se tratando da aludida Convenção TÂNIA PEREIRA realça que "o grande desafio constituiu em definir direitos universais para as crianças, considerando a diversidade de percepções religiosas, socioeconômicas e culturais da infância nas diversas nações". 21

\subsubsection{Um olhar para dentro: evolução normativa brasileira quanto às crianças e aos adolescentes.}

Em território nacional, a primeira vez que apareceu no ordenamento jurídico o tema "direitos das crianças e dos adolescentes" foi na Constituição de

\footnotetext{
${ }^{19}$ BARROS, Nívea Valença. Violência intrafamiliar contra a criança e adolescente. Trajetória histórica, políticas, sociais, práticas e proteção social. 2005. 248 p. Tese de Doutorado. Departamento de Psicologia, Pontifícia Universidade Católica do Rio de Janeiro. Rio de Janeiro, 2005, p.74.

20 MELO, Edson Ulisses de. Sociedade mais punitiva colherá mais violência. Disponível em <https://www.conjur.com.br/2014-mar-27/edson-melo-sociedade-punitiva-colhera-violencia>Acesso em 22 de abril de 2018.

${ }^{21}$ PEREIRA, Tânia da Silva. Direito da Criança e do Adolescente: uma proposta interdisciplinar. 2 ed. rev e atual. Rio de Janeiro: Renovar, 2008, p. 592.
} 
1934 que levantou questões trabalhistas envolvendo as crianças e os adolescentes, reprimindo trabalhos noturnos as crianças de até 16 anos e proibindo de igual forma, menores de 18 anos a trabalharem em ambientes insalubres. $^{22}$

Na Constituição seguinte, datada de 1937, surgiu no cenário legislativo a proteção social voltada para as crianças e adolescentes, determinando ainda a competência privativa da União para legislar a respeito da defesa e proteção da saúde do menor. ${ }^{23} \mathrm{Na}$ Carta Maior de 1937, ainda houve outra inovação, onde o Estado chamou para si e para os Municípios a responsabilidade de assegurar as garantias da infância e da juventude. ${ }^{24}$

Com o advento da Constituição de 1988, houve uma ampliação considerável na proteção e na garantia dos direitos dos menores, inclusive, cabe destacar a presença inovadora da sociedade como responsável pelos cuidados em relação aos pequenos. Firmou-se então, princípios constitucionais, os quais serão aprofundados em tópicos seguintes que regem o ordenamento jurídico brasileiro no que diz respeito aos menores de 18 anos, sendo dois deles: o princípio do melhor interesse da criança e o princípio da proteção integral.

Sobre a Constituição de 1988, explica MIGUEL BRUNOL: “a população infanto-juvenil deixa de ser tutoria/discriminatória para tornar-se sujeito de direitos". ${ }^{25}$ Pois bem. A partir da promulgação da CRFB vigente que trouxe em seu texto o artigo 227 e seus decorrentes princípios, em 1990 surge o Estatuto da Criança e do Adolescente.

A respeito do ECA, MAURÍCIO JESUS pontua:

\footnotetext{
${ }^{22}$ LIBERATI, Wilson Donizeti. Adolescência e ato infracional - Medida socioeducativa e pena?; São Paulo: Juarez de Oliveira, 2002, p. 31.

${ }^{23}$ Constituição Federal de 1937: art. 16, XXVII: "Compete privativamente à União o poder de legislar sobre as seguintes matérias: normas fundamentais da defesa e proteção da saúde, especialmente da saúde da criança".

${ }^{24}$ JESUS. Maurício Neves. Adolescente em conflito com a lei: prevenção e proteção integral. Campinas: Savanda, 2006, p. 38.

${ }^{25}$ BRUNOL, Miguel Cillero. O interesse superior da criança no marco da Convenção Internacional sobre os Direitos da Criança. In: Méndez, Emílio Garcia.; Beloff, Mary (org.) Infância, lei e democracia na América Latina: análise crítica do panorama legislativo no marco da Convenção Internacional Sobre os Direitos da Criança. Trad. Eliete Avila Wolff. Blumenal: Edifurb, 2001, p. 39.
} 
O Estatuto da Criança e do Adolescente (Lei $n^{\circ}$ 8.069/90) institui a doutrina da proteção integral à criança e ao adolescente, considerando criança a pessoa com até 12 anos incompletos, e adolescente aquela entre 12 e 18 anos, fixando-lhes os direitos e deveres e prevendo as medidas aplicáveis àqueles que afrontem os seus preceitos legais. ${ }^{26}$

O ECA surge atribuindo às crianças e aos adolescentes direitos fundamentais, tais como: respeito à liberdade, dignidade, saúde, convívio familiar, dentro outros. O Estatuto visou à proteção do infante em relação a qualquer poder abusivo que, por ventura, possa ser acometido por parte da família, da sociedade ou até mesmo do Estado. ${ }^{27}$ A partir dessa premissa, tornase evidente que a proteção da criança e do adolescente é, nos dias atuais, uma obrigação de todos.

Por fim, conclui-se nas palavras da doutrinadora JOSIANE VERONESE:

O Estatuto da Criança e do Adolescente veio pôr fim a estas situações e tantas outras que implicavam numa ameaça aos direitos da criança e dos adolescentes, suscitando, no seu conjunto de medidas, uma nova postura a ser tomada tanto pela família, pela escola, pelas entidades de atendimento, pela sociedade e pelo Estado, objetivando resguardar os direitos das crianças e adolescentes, zelando para que não sejam sequer ameaçados. ${ }^{28}$

As inovações legislativas voltadas para as crianças não cessam por aí. Importante trazer a baila, o chamado Estatuto da Primeira Infância (Lei 13.257 de 2016), o qual foi responsável por uma série de modificações tanto no ECA, como na Consolidação das Leis Trabalhistas e no Código de Processo Penal. O mencionado Estatuto identificou a primeira infância como sendo o período compreendido entre os 0 meses a 6 anos completos de um individuo e criou diversas políticas públicas voltadas a atender as necessidades dessa faixa etária.

Dentre as inovações trazidas por este importante Estatuto, elementar que se mencione a inclusão do parágrafo primeiro do artigo 13 do $\mathrm{ECA}^{29}$, no qual determina-se que as mães que expressem seu interesse em levar seus filhos para adoção devem ser encaminhadas à Justiça da Infância e da Juventude, sendo

\footnotetext{
${ }^{26}$ JESUS. Maurício Neves. Op. cit., p. 65.

${ }^{27}$ FREIRE NETO, João Francisco. Princípios Fundamentais do Estatuto da Criança e do Adolescente. Rio de Janeiro: Renovar, 2007, p. 257.

${ }^{28}$ VERONESE, Josiane Rose Petry. Temas de Direito da Criança e do Adolescente. São Paulo: LTr, 1997, p. 11

${ }^{29}$ ECA - Lei 8.069 de 1990. Art. 13, parágrafo 1: “As gestantes ou mães que manifestem interesse em entregar seus filhos para adoção serão obrigatoriamente encaminhadas, sem constrangimento, à Justiça da Infância e da Juventude."
} 
certo que nesse processo não haja um constrangimento. Essa inclusão é de enorme importância eis que se trata de uma tentativa de conscientização e prevenção, evitando que diversas crianças sejam entregues a adoção, quando não presentes as condições para tanto, ou seja, quando o infante não se encontra em verdadeira situação de risco e abandono.

Ademais, fora incluído ainda pelo Estatuto da Primeira Infância o parágrafo 5 ao artigo 102 do $\mathrm{ECA}^{30}$, de enorme importância. O referido parágrafo estipula que as certidões e registros necessários a incluso do nome do pai no assento de nascimento de seu filho, devem ter absoluta prioridade bem como devem ser gratuitas. Essa medida é primordial para garantia de uma série de direitos da criança e do adolescente, efetivando principalmente o princípio do melhor interesse da criança e do adolescente em ter em seus documentos o nome de seu pai.

As inovações do Estatuto da Primeira infância na seara trabalhista foram de extrema significância, a começar pela inclusão do inciso XI no artigo 473 da $\mathrm{CLT}^{31}$, o qual concedeu, sem prejuízo do salário, ao empregado faltar o trabalho para acompanhar por um dia seu filho até 6 anos em uma consulta médica.

É evidente que essa concessão se mostra bastante limitada eis que um dia ao ano talvez não seja suficiente, entretanto, é de considerável importância, eis que garante que a criança seja assistida pelos seus pais e, que estes tenham um acompanhamento direto com o médico do infante. A referida inclusão legislativa garante uma segurança maior aos pequenos além de garantir a possibilidade de maior conhecimento dos pais sobre a vida dos filhos.

O Estatuto da Primeira Infância alterou também a Lei 11.770 de 2008, possibilitando um aumento na chamada licença paternidade, a qual tem o tempo estipulado de 5 (cinco) dias pela CRFB, para um período de até 20 dias. A evolução nesse ponto, igualmente mostrou-se tímida devido ao curto período

\footnotetext{
${ }^{30}$ ECA - Lei 8.069 de 1990. Art. 102, parágrafo 5: "Os registros e certidões necessários à inclusão, a qualquer tempo, do nome do pai no assento de nascimento são isentos de multas, custas e emolumentos, gozando de absoluta prioridade."

${ }^{31}$ CLT - Art. 473, XI: "O empregado poderá deixar de comparecer ao serviço sem prejuízo do salário: por 1 (um) dia por ano para acompanhar filho de até 6 (seis) anos em consulta médica."
} 
concedido, entretanto não é prudente não reconhecer o avanço legislativo. Com o aumento no período da licença paternidade, os pais podem ter garantido um maior convívio com seus filhos recém-nascidos, suprindo de maneira mais eficaz as suas necessidades.

Por fim, cabe destacar intensas modificações trazidas por este Estatuto no campo do direito penal, resguardando o cuidado devido aos filhos pequenos de detentos. Com este fito, foi incluído no artigo 6 do Código de Processo Penal ${ }^{32}$ uma nova obrigação ao delegado quanto este tiver conhecimento da infração penal, qual seja, de verificar a existência de filhos por parte do indivíduo preso e de averiguar seu respectivo responsável.

Em adição a isto, o Estatuto incluiu duas novas possibilidades para prisão preventiva domiciliar $^{33}$ com o objetivo de garantir o melhor interesse da criança, quais sejam: quando a mulher tiver filho com até 12 (doze) anos incompletos ou quando o homem for o único responsável pelos cuidados de seu filho de até 12 (doze anos). Além de garantir proteção à criança, essa medida foi capaz de garantir o convívio familiar, tão importante nessa fase de formação dos pequenos.

Diante dessas diversas inovações jurídicas trazidas, constata-se que o Estatuto da Primeira Infância ocupou lugar de destacada importância no campo dos direitos e conquistas das crianças, representando, portanto, um avanço memorável no campo de estudo do direito.

Como mencionado em momento anterior, conta-se ainda com outra legislação específica publicada em 2013 que abrange os jovens compreendidos entre 15 (quinze) a 29 (vinte e nove) anos de idade, o Estatuto da Juventude (Lei 12.852/13). O surgimento deste ato normativo se deu devido ao reconhecimento de necessidades e cuidados especiais a um grupo de indivíduos que não se enquadravam no conceito de adolescentes dado pelo ECA.

\footnotetext{
${ }^{32} \mathrm{CPP}$ - Art. 6, X: "colher informações sobre a existência de filhos, respectivas idades e se possuem alguma deficiência e o nome e o contato de eventual responsável pelos cuidados dos filhos, indicado pela pessoa presa."

${ }^{33}$ CPP - Art. 318, V: "Poderá o juiz substituir a prisão preventiva pela domiciliar quando o agente for: mulher com filho de até 12 (doze) anos de idade incompletos" e VI: "homem, caso seja o único responsável pelos cuidados do filho de até 12 (doze) anos de idade incompletos".
} 
Com o surgimento do aludido Estatuto criou-se o Sistema Nacional de Juventude - SINAJUVE, que visa uma construção de políticas públicas destinadas a esse grupo que colaboram com a construção do futuro do país. Essas políticas públicas são voltadas para inúmeros direitos, como por exemplo, saúde, educação, trabalho, cultura esporte, livre associativismo, entre outros.

O objetivo final do Estatuto é garantir a inserção dos jovens na sociedade brasileira em condições dignas de ocupar posições centrais em processos políticos e sociais. ${ }^{34}$ Como o aludido ato normativo refere-se, em sua grande maioria, a pessoas com idade superior a 18 anos, não restam muitos questionamentos quanto às suas respectivas autonomias em caráter civil ${ }^{35}$. Assim sendo, não se despendera um olhar mais atento neste trabalho para esse grupo carecedor de cuidados especiais compreendidos entre 18 (dezoito) e 29 (vinte e nove) anos.

Diante de todo o exposto, pode-se constatar que a evolução legal a respeito das crianças e dos adolescentes no Brasil foi lenta e, por muitas vezes, pareceu caminhar a passos curtos. Contudo, chegou-se na atualidade a um compilado de normas e princípios, o qual visa não só a proteção como também objetiva garantir um desenvolvimento digno aos menores.

É de notório conhecimento que o Estado brasileiro não efetiva por completo toda a proteção que prevê e, não garante, por vezes, o pilar básico de todo o sistema, qual seja: a dignidade da pessoa humana. No entanto, não se deve fechar os olhos para toda evolução que o país tem passado, não só em reconhecer os direitos dos menores como em também torná-los cada vez mais amplos.

Diante do entendimento já firmado a respeito da autonomia da vontade e, consoante à legislação pertinente ora apresentada a respeito dos sujeitos em questão, eleva-se no momento ao estudo das limitações da aludida autonomia do menor. Essas por sua vez, podem ser diferenciadas e analisadas através de três

\footnotetext{
34 JUNQUEIRA, Alice. Estatuto da Juventude: o jovem como sujeito de direitos!. Disponível em $<$ http://pagina22.com.br/2013/08/12/estatuto-da-juventude-o-jovem-como-sujeito-de-direitos/>. Acessado em 20 de abril de 2018.

${ }^{35}$ A maioridade no Brasil é alcançada aos 18 anos, quando se adquire total capacidade para exercer todos os atos da vida civil.
} 
grandes caminhos, sendo eles: o regime jurídico de incapacidades do qual são acometidos; o poder familiar que recai sobre eles como forma de limitação a autonomia e, por fim, os princípios trazidos pela CRFB de proteção ao melhor interesse e tutela integral.

\subsection{Incapacidade e menoridade: conceitos indissociáveis.}

$A b$ initio, para que se tenha entendimento pleno acerca das limitações à autonomia da criança e do adolescente, faz-se mister destacar o status indissociável das crianças e dos adolescentes dado pelo ordenamento jurídico brasileiro vigente, qual seja, de incapazes ou relativamente incapazes, a depender da idade.

De acordo com o artigo $3^{\circ}$ do Código Civil: "São absolutamente incapazes de exercer pessoalmente os atos da vida civil os menores de 16 (dezesseis) anos". Ao passo que o artigo $4^{\circ}$, I do aludido Código determina: "São incapazes, relativamente a certos atos ou à maneira de os exercer: I - os maiores de dezesseis e menores de dezoito anos".

O referido status pode ser modificado com a maioridade ou à medida que certas situações, previamente determinadas por lei, venham a ocorrer e, por conseguinte, tenham o condão de derrubar a barreira da incapacidade da criança. As aludidas situações estão elencadas no artigo $5^{\circ}$, parágrafo único e seus incisos do Codex civil.

A incapacidade ou a relativa incapacidade, por sua vez, são responsáveis por um tratamento jurídico diferenciado àqueles que a detêm. Logo, pode-se notar de plano que os menores de 18 anos terão tratamento jurídico distinto dos

plenamente capazes, isso devido a sua particularidade, qual seja, a tenra idade e, seus consequentes adjetivos.

Este tratamento jurídico diferenciado surge como uma tentativa de proteger a criança e o adolescente, que é visto pelo ordenamento jurídico como vulnerável. Isso, pois, encontra-se em uma fase sensível de desenvolvimento psicológico, moral, mental, físico, dentro outros, o que o torna, segundo a 
doutrina, facilmente influenciáveis e manipuláveis, carecendo assim de um tratamento distinto dos demais. Nesse sentido, leciona CAIO MÁRIO:

O instituto das incapacidades foi imaginado e construído sobre uma razão moralmente elevada, que é a proteção dos que são portadores de uma deficiência juridicamente apreciável. Esta é a ideia fundamental que o inspira, e acentuá-lo é de suma importância para a sua projeção na vida civil, seja no tocante à aplicação dos princípios legais definidores, seja na apreciação dos efeitos respectivos ou no aproveitamento e na ineficácia dos atos jurídicos praticados pelos incapazes. ${ }^{36}$

Nesta linha de raciocínio, ROLF MADALENO destaca o caráter vulnerável dos pequenos justificando assim, seu regime jurídico diferenciado:

A vulnerabilidade dos infantes é decorrência natural da dependência que eles têm dos adultos, pois podem ser pacientes das mais variadas formas de agressão, assim como vitimas de uma violência corporal ou sexual, ou de abandono físico, psicológico, afetivo ou material. Qualquer ofensa à integridade física ou psíquica do infante converte a sua vida em um emaranhado de consequências devastadoras. Por isso que ao menor abalo a sua integridade física, psicológica ou financeira, a ameaça precisa ser pronta e prioritariamente neutralizada, e essa proteção depende da atividade dos adultos e de seus responsáveis diretos, pais, tutores e representantes, para que os menores cresçam sem temores, sem percalços e conquistem no devido tempo seus próprios mecanismos de defesa e de sobrevivência, e desse modo possam gerar paulatinamente a sua independência, em conformidade com os seus níveis de autodeterminação, que vão mudando de acordo com o avanço de sua idade, e assim desenvolver sua personalidade, adquirir confiança, autoestima, e se colocar a salvo das sequelas causadas pela insensibilidade dos adultos. ${ }^{37}$

Contudo, importante trazer a baila o caráter limitador que tal status traz à autonomia da criança e do adolescente. Inclusive, acerca desta questão, a professora THAÍ́S SECCO, em sua dissertação de mestrado, defende que a imposição da incapacidade pode acabar por ameaçar o exercício espontâneo dos interesses existenciais das crianças e dos adolescentes ao invés de proteger, a depender do limite. Se não, vejamos:

A crítica às incapacidades está em que, tidos por vulneráveis os chamados incapazes, é imprescindível indagar de que maneira a incapacidade se propõe a os proteger do que os ameaça sem deixar de indagar - principalmente - até que ponto não é a própria atribuição do status de incapaz que não se revela como uma das maiores ameaças que pendem sobre essas pessoas a implementar a vulnerabilidade que, de resto, é condição

\footnotetext{
${ }^{36}$ PEREIRA. Caio Mário da Silva. Instituições do direito civil. 26 ed - Rio de Janeiro: Forense, 2013., p. 230.

${ }^{37}$ MADALENO, Rolf, 1954 - Curso de direito de família/Rolf Madaleno - 6. ed. rev., atual. e ampl. Rio de Janeiro: Forense, 2015. p. 60
} 
de todo ser humano. A critica, como se pode ver, se dirige quase que inteiramente às incapacidades. ${ }^{38}$

Para que se compreenda as limitações impostas à autonomia das crianças e dos adolescentes, no que tange a condição de vulnerável que os imputam, importante adentrar mais profundamente ao conceito de capacidade.

\subsubsection{Instituto da (in)capacidade.}

O instituto de direito civil denominado "capacidade" não pode ser confundido com outro instituto civilista denominado "personalidade", embora tenham uma ligação intima um com o outro. A personalidade é inerente a todo e qualquer ser humano sendo certo, portanto, que todos podem contrair tanto obrigações como direitos. Inclusive, neste sentido preceitua o artigo $1^{\circ}$ do Código Civil: “Todas as pessoas são capazes de direitos e deveres na ordem jurídica”.

Em contrapartida, a "capacidade", não é inerente a todo e qualquer ser humano, apresentando um caráter mais limitador em relação ao primeiro instituto. O status da capacidade faz com que a pessoa contraia direitos e obrigações respondendo por eles de maneira própria, pessoal.

A partir desse esclarecimento, diferenciam-se dois conceitos importantes ao nosso estudo: capacidade de fato e capacidade de direito. Acerca do tema CAIO MÁRIO comenta: “a esta aptidão oriunda da personalidade, para adquirir os direitos na vida civil, dá-se o nome de capacidade de direito, e se distingue da capacidade de fato, que é a aptidão para utilizá-los e exercê-los por si mesmo". 39

Neste diapasão, percebe-se que o incapaz é dotado de capacidade de direito, entretanto carece de capacidade de fato. Há, portanto uma limitação ao poder de agir dos que são cobertos pelo manto da incapacidade. Assim o é, pelo fato de não poderem responder pessoalmente pelos seus direitos e obrigações, necessitando de assistência ou representação.

\footnotetext{
${ }^{38}$ SÊCO, Thaís. A autonomia da criança e do adolescente e suas fronteiras: capacidade, família e direitos da personalidade. 2013. Dissertação (Mestrado em Direito) - Universidade do Estado do Rio de Janeiro, Rio de Janeiro, 2013., p. 17.

${ }^{39}$ PEREIRA. Caio Mário da Silva. Instituições de direito civil. cit., p. 223.
} 
Como exposto anteriormente, as crianças e os adolescentes são incapazes, entretanto, a depender de sua idade podem ter essa incapacidade relativizada, como é o caso dos maiores de 16 anos. Tendo isto posto, passa-se ao estudo desta absoluta incapacidade e da incapacidade em sua forma relativizada.

\subsubsection{Absolutamente incapazes.}

A incapacidade absoluta se da apenas pela idade, de acordo com a nova redação do artigo $3^{\circ}$ do Código Civil trazida pelo Estatuto da Pessoa com Deficiência (Lei $\mathrm{n}^{\circ} 13.146$ de 2015). O referido estatuto, também conhecido como Lei de inclusão à pessoa com deficiência, alterou o dispositivo excluindo seus incisos I e III que classificavam como absolutamente incapazes os enfermos ou detentores de doenças mentais além daqueles que não possuíssem discernimento para os atos, ainda que transitoriamente.

Quanto à idade, fator mantido pelo Estatuto, foi escolhido pelo legislador brasileiro, em caráter arbitrário, o marco de 16 anos para decair tal incapacidade em sua forma absoluta. Ainda que se admita a possibilidade de cada individuo ter seu momento para adquirir os predicados necessários ao estabelecimento de seus contatos diretos com o mundo jurídico, preferiu-se optar pela estabilidade das relações sociais, arbitrando uma idade para que a incapacidade deixasse de ser absoluta e fosse, ao menos, relativizada. ${ }^{40}$

\subsubsection{Relativamente incapazes.}

A situação aqui existente pode ser localizada entre a incapacidade absoluta de realizar os ato da vida civil e a plena capacidade de efetuá-los por conta e nome próprio. Logo, os relativamente incapazes gozam de mais autonomia do que os absolutamente incapazes ao passo que ainda são restringidos em relação ao seu gozo pleno.

Isso porque, o direito brasileiro entendeu que os maiores de 16 anos já possuem um discernimento avançado ao ponto de serem capazes de manifestar as

\footnotetext{
${ }^{40}$ PEREIRA. Caio Mário da Silva. Instituições de direito civil. cit., p. 232.
} 
suas vontades, entretanto, não de forma ilimitada. No que diz respeito ao marco inicial e final desta relativização, quais sejam, 16 e 18 anos respectivamente, o legislador também os determinou de maneira arbitraria.

Com a entrada em vigor do Código Civil de 2002, a partir dos 18 anos, pelo critério etário, o individuo é plenamente capaz, sendo certo que a maioridade no Código Civil de 1916 era atingida aos $21 \operatorname{anos}^{41}$.

Considera-se para o mundo jurídico, portanto, que após a aludida idade, o ser humano já alcançou discernimento suficiente para fazer suas próprias escolhas e exercer de maneira plena os atos da vida civil, além de responder pelas suas consequências em nome próprio. Nesta linha de raciocínio a respeito da capacidade, MARIA HELENA DINIZ ensina:

(...) é a aptidão de exercer por si os atos da vida civil, dependendo, portanto, do discernimento, que é critério, prudência, juízo, tino, inteligência, e, sob o prisma jurídico, da aptidão que tem a pessoa de distinguir o lícito do ilícito, o conveniente do prejudicial. ${ }^{42}$

\subsubsection{Representação e Assistência.}

Superada a análise das categorias de incapacidade, nota-se que os indivíduos que estejam sob total ou parcial restrição de agir em razão da idade, necessitam de outrem para que assim tenham destacados e resguardados seus direitos e interesses em possíveis atos que estejam relacionados.

Baseado nessa premissa, o direito brasileiro conta, em especial, com dois elementos que cumprem o referido intuito: a representação e a assistência. Neste sentido, pontua o atual ministro do STF, Luiz Edson Fachin:

A lei funda o débil, com seu estatuto de incapacidade, e ao mesmo tempo oferta, por receita, o remédio instrumental da debilidade. Nesta moldura, se apresentam os sujeitos de direito: mãe, pai, filhos menores não emancipados, tutor e curador. ${ }^{43}$

\footnotetext{
${ }^{41}$ Artigo 6, I do Código Civil de 1916: "São incapazes relativamente a certos atos (art. 147, n I) ou a maneira de os exercer: I - os maiores de 16 anos e os menores de 21 anos (arts. 154 e 156)."

${ }^{42}$ DINIZ. Maria Helena. Curso de Direito Civil Brasileiro: Teoria Geral do Direito Civil. 21. ed. rev., aum. e atual de acordo com o novo Código Civil. São Paulo: Saraiva, 2004. p.142.

${ }^{43}$ FACHIN. Luiz Edson. Elementos críticos do direito de família. Rio de Janeiro: Renovar, 1999, p. 223.
} 
A representação, como o próprio nome nos diz, trata de representar o absolutamente incapaz por este não poder exprimir suas vontades, uma vez que o direito brasileiro considera que ele não tem discernimento, vivência e, consequente maturidade suficiente para isto. A respeito do tema, o ilustre doutrinador, CAIO MARIO, defende:

A ligação que se estabelece entre os absolutamente incapazes e a vida jurídica é indireta, por via do instituto da representação (cf. n 106, infra). Como são eles inteiramente afastados de qualquer atividade no mundo jurídico, naqueles atos que se relacionam com seus direitos e interesses, procedem por via de representantes, que agem em seu nome, falam, pensam e querem por eles. ${ }^{44}$

Neste sentido, dispõe a doutrina que o representante tem o papel de decidir pelo representado, uma vez que entende que ele não tem condições para tomar suas decisões e realizar suas escolhas. Por outro lado, contamos com o instituto da assistência, o qual serve de auxilio para os relativamente incapazes.

A utilização do termo auxilio não é em vão. Isso porque como dito em momento anterior, os relativamente incapazes não possuem autonomia plena para o exercício da vida civil, porém não são totalmente cerceados desta. O legislador entendeu que os menores compreendidos entre 16 (dezesseis) e 18 (dezoito) anos já possuem um certo desenvolvimento que os tornam capazes de exprimir suas vontades, mas não sem amparo de outrem. Sob esta égide, continua o nobre doutrinador civilista:

Os menores relativamente incapazes, por conseguinte, figuram nos atos jurídicos, mas a validade destes requer a assistência de seu pai ou de sua mãe, conforme estejam sob o poder familiar ou aos cuidados de um tutor, se em regime tutelar. (...) Em alguns casos, o menor relativamente incapaz procede independentemente da presença de um assistente. Assim é que pode aceitar mandato (art. 666), fazer testamento (art. 1860) e ser testemunha em atos jurídicos (art. 228). Ressalvadas as normas de proteção relativas a horários de trabalho, à natureza insalubre da atividade e à faculdade de obsta-lo, conferida aos pais, tutor ou responsável, o menor relativamente incapaz pode ajudar contrato de trabalho. ${ }^{45}$

Aqui não se trata de uma representação onde se substitui o representado e sim de uma tomada de decisão lado a lado, onde a vontade do menor deve ser

\footnotetext{
${ }^{44}$ PEREIRA. Caio Mário da Silva. Instituições de direito civil. cit., p. 231.

${ }^{45}$ PEREIRA. Caio Mário da Silva. Instituições de direito civil. cit., p. 239.
} 
escutada e levada em consideração. A tomada de decisões na assistência é feita de maneira conjunta, o que ao revés, não é o que ocorre na representação já que, em regra, as tomadas de decisões são unilaterais.

\subsubsection{A sensível questão do discernimento dos pequenos para imposição de sua incapacidade e a teoria do menor maduro.}

Consoante à doutrina brasileira e, conforme apresentado ate o presente momento, a imposição do status de incapaz ou relativamente incapaz ao menor foi uma escolha do legislador em um intuito de proteção, que por sua vez, é baseado na suposta ausência de discernimento e maturidade dos protegidos.

No entanto, diante do cenário atual pautado na diversidade humana, cada vez mais latente aos nossos olhos, podemos perceber, sem grande esforço, que cada ser humano possui um lapso temporal específico para atingir determinado ponto de discernimento. Esse momento vai variar de acordo com uma série de fatores, onde alimentação, níveis de estudo, qualidade do ambiente familiar, saúde são apenas alguns deles.

Neste sentido, não se faz necessário tecer grandes comentários acerca dos motivos pelos quais, o modelo de imposição de incapacidade, tal qual nos é apresentado, encontra-se totalmente ultrapassado.

Isso porque a incapacidade é imposta ao menor de maneira arbitrária por parte do legislador que somente levou em consideração a faixa etária. Por motivos lógicos, o sistema civilista de (in)capacidades ignora as diversidades naturais e inerentes aos seres humanos, igualando a vontade e o discernimento de jovens de 15 anos a recém-nascidos, o que torna inquestionável a sua insustentabilidade.

Nesta perspectiva, a advogada ANA CAROLINA BROCHADO TEIXEIRA, em seu artigo Autonomia Privada da Criança e do Adolescente: uma Reflexão sobre o Regime das Incapacidades é clara ao constatar:

Todavia, o regime das incapacidades, da maneira em que se encontra regulado no Código Civil, disposto numa "serie estereotipada de limitações, proibições e exclusões", pode impedir o exercício da autonomia privada por aquele que, porventura, já tenha 
condições de exercê-la em determinadas situações, suprimindo a subjetividade e o desenvolvimento da personalidade. ${ }^{46}$

Sob esta questão, imperioso trazer ao presente estudo um caso concreto que surgiu na Inglaterra na década de 80, e foi julgado pela Corte dos Lordes, conhecido como Gillik x Norfolk $^{47}$. Esse leading case acabou por fundar a "teoria do menor maduro" que influenciou e, influencia uma série de tomadas de decisões tanto legislativas como jurisprudenciais mundo afora, no sentido de diminuir a cobertura de incapacidade dada aos menores, sem que ao menos, avalie-se o discernimento do ser humano de forma individual.

Nesse caso em específico, uma mãe ajuizou ação judicial para derrubar um decreto de uma autoridade de saúde inglesa, no qual se estabeleceu a ausência de obrigação do médico em consultar ou informar aos pais, a respeito de anticoncepcionais que tenham sido solicitados por jovens de 16 anos.

A autora da ação judicial entendeu que isso violaria seu direito parental, o que não foi aceito pela Corte dos Lordes, uma vez que se entendeu caber ao médico à avaliação do discernimento da adolescente ao ponto de analisar se ela estaria ou não madura para o tratamento anticoncepcional.

Essa decisão fundou a "teoria do menor maduro" a qual se fundamenta na questão da prova pericial, verificando assim, isoladamente, a questão do discernimento da criança e do adolescente para tal ato. Nas palavras de THAÍs SECO:

A proposta da teoria do menor maduro visa uma solução, mais uma vez, em analogia ao mecanismo de promoção da individualidade e do pluralismo com relação ao indivíduo adulto. Consiste, na verdade, em avaliar o quanto a criança e o adolescente podem ser considerados próximos do padrão do "homem médio". ${ }^{48}$

\footnotetext{
${ }^{46}$ TEIXEIRA, Ana Carolina Brochado. Autonomia Privada da Criança e do Adolescente: uma Reflexão sobre o Regime das Incapacidades. In: Revista Brasileira de Direito das Famílias e Sucessões. Belo Horizonte: Magister, 2007. p. 59-73.

${ }^{47}$ Gillick $x$ West Norfolk \& Wisbeck Area Health Authority (1986). Disponível em <www.bailii.org>. Acessado em 23.03.2018.

${ }^{48}$ SÊCO, Thaís. Por uma nova hermenêutica do direito da criança e do adolescente. Civilistica.com. Rio de Janeiro, a. 3, n. 2, jul. - dez./2014. Disponível em: http://civilistica.com/por-uma-nova-hermeneuticado-direito-da-criança-e-do-adolescente/> Acessado em 23.03.2018.
} 
Atentas a esta falha na legislação e influenciados pela "teoria do menor maduro" supracitada, doutrina e jurisprudência brasileira se posicionaram no sentido de relativizar o disposto nos artigos $3^{\circ}$ e $4^{\circ}$, I do Código Civil. Assim dispõe o Enunciado n. 138 do CJF/STJ, aprovado na III Jornada de Direito Civil: "a vontade dos absolutamente incapazes, na hipótese do inc. I do art. $3^{\circ}$, é juridicamente relevante na concretização de situações existenciais a eles concernentes, desde que demonstrem discernimento bastante para tanto”.

Prosseguindo nesta égide de relativizar o disposto no Código Civil no que tange as incapacidades, importa dizer que a vontade dos menores, ainda que absolutamente incapazes, é relevante para os casos envolvendo adoção e guarda, onde cabe sua oitiva para expressarem sua posição.

Inclusive, importante destacar que nos casos em que se trata de adoção de maiores de 12 anos, o consentimento do menor mostra-se essencial ao ato (Lei 8.069/90 ECA - "Art. 45. A adoção depende do consentimento dos pais ou do representante legal do adotando. $\S 2^{\circ}$ Em se tratando de adotando maior de doze anos de idade, será também necessário o seu consentimento"). ${ }^{49}$

Ainda sob esta ótica, observa-se o disposto no artigo 28 do ECA, o qual confere as crianças e aos adolescentes direito à voz, todas as vezes que possuírem discernimento para tal ${ }^{50}$.

Curioso observar que os adolescentes relativamente incapazes podem, cumpridos os requisitos legais que serão explorados mais a frente, sofrerem uma antecipação da maioridade civil através do instituto denominado emancipação, o que os traz a capacidade civil plena.

No que diz respeito aos jovens com idade compreendida entre 16 e 18 anos, não restam dúvidas que suas vontades, ideias, considerações são trazidas de forma mais frequente em relação aos absolutamente incapazes. Isso é refletido até mesmo no modo pelo qual sua autonomia é trazida ao mundo jurídico, ou

\footnotetext{
${ }^{49}$ TARTUCE, Flavio. Manual de direito civil: volume único. 7 ed. rev., atual e ampl. - Rio de Janeiro: Forense, São Paulo: METODO, 2017. p. 88.

${ }^{50}$ ECA - Lei 8.069 de 13 de julho de 1990. Art. 28, parágrafo 1: "Sempre que possível, a criança ou o adolescente será previamente ouvido por equipe interprofissional, respeitado seu estágio de desenvolvimento e grau de compreensão sobre as implicações da medida, e terá sua opinião devidamente considerada."
} 
seja, através da assistência e não mais da representação, como explicado através do tópico 1.3.2.

Sendo assim, percebe-se que a execução direta de direitos e obrigações esta consideravelmente mais próxima dos jovens com 16 anos do que dos jovens de 15 anos e 3 meses, por exemplo. E encontram-se justamente nessa sensação de "longe-perto" as maiores questões acerca da autonomia da criança e do adolescente que quando não observadas com a sensibilidade que requerem, podem causar danos irreparáveis.

Cobrir com um manto de incapacidade completa indivíduos de 0 a 16 anos de forma uniforme, faz com que individualmente oportunidades, crescimentos, sonhos sejam reprimidos sem que se observe o real desenvolvimento necessário para tomada daquela decisão no caso concreto que, muitas vezes já fora alcançado.

Além da crítica subjetiva que se direciona a ausência de real comprovação quanto ao grau de discernimento daquela criança/adolescente em especifico, fazse pertinente, observar constantemente o real grau de comprometimento que o representante legal detém em relação ao menor, o que acaba por tornar a presença do Estado nessa questão eticamente justificável, como se verá no Capítulo seguinte. Afinal, é o representante legal quem vai decidir a respeito de todas as esferas da vida do representado com base nos seus entendimentos e convicções.

A questão mostra-se cada vez mais complexa uma vez que não se pode olvidar que aqui, trata-se de pessoas de tenra idade e com um longo caminho de vida pela frente. Desta maneira, não parece cauteloso ignorar a vulnerabilidade existente neste período de desenvolvimento da vida. No entanto, não parece igualmente cauteloso não verificar de forma digna a maturidade $\mathrm{e} o$ discernimento de jovens de maneira individualizada que, a depender do momento, podem estar bastante avançadas.

A solução ao problema levantado não é unanime e, muito menos, mostrase madura e consolidada. Todavia, é o primeiro passo para que se repense o 
modelo tal qual é utilizado nos dias de hoje e, instigue desfechos mais completos e justos com a sociedade. A possível conclusão é trazida pela advogada ANA CAROLINA BROCHADO TEIXEIRA:

Deve-se, portanto, fazer uma nova interpretação do regime das incapacidades, tendo-se em vista a ratio que o fundamenta: a tutela da dignidade humana, de alguém que se encontra em fase de desenvolvimento. Nesse sentido, deve-se proteger aquele que não tem discernimento e respeitar a liberdade e a subjetividade daquele que tem condições de decidir por si mesmo. Essa releitura do regime das incapacidades só é possível, portanto, com o equilíbrio entre poder familiar e principio da autonomia privada como institutos complementares - e não opositores - um do outro. ${ }^{51}$

E, por fim, a autora conclui com maestria:

E para que essa nova hermenêutica seja possível, é preciso que o regime das incapacidades tenha como finalidade precípua a aplicação nas situações jurídicas patrimoniais, de modo que, nas existenciais, a maturidade do menor - caso ela exista seja considerada. Por isso, cada caso levado para apreciação do Poder Judiciário deve ser analisado individualmente, com base nas condições de criação, estudo e discernimento do menor envolvido e não ficar restrito apenas aos critérios objetivos dispostos no Código Civil. Só assim o regime das incapacidades realizará sua verdadeira finalidade protetiva, sem suprimir a subjetividade dos sujeitos - ativos ou passivos - envolvidos. ${ }^{52}$

Sob esta égide e voltada para as questões existenciais do menor, MARIA CELINA BODIN DE MORAES, defende que ainda que os menores estejam sob autoridade parental, deve haver uma "presunção de capacidade" em se tratando de direitos fundamentais da criança e do adolescente, ao invés de se estabelecer a incapacidade de plano, atribuindo-se à eles a capacidade do exercício de tais direitos. ${ }^{53}$ Posto isso, passa-se ao tema do poder familiar que ocupa grande destaque quando se trata da autonomia dos menores.

\footnotetext{
${ }^{51}$ TEIXEIRA, Ana Carolina Brochado. Autonomia Privada da Criança e do Adolescente: uma Reflexão sobre o Regime das Incapacidades. In: Revista Brasileira de Direito das Famílias e Sucessões. Belo Horizonte: Magister, 2007. p. 59-73

52 Idem.

53 BODIN DE MORAES, Maria Celina. A família democrática. In: Na medida da pessoa humana: estudos de direito civil-constitucional. Rio de Janeiro: renovar, 2010, p. 209.
} 


\section{4 poder familiar entendido como uma forma de limitação à autonomia da criança e do adolescente.}

Devido à complexidade e extensão do assunto que passa a ser tratado adiante, qual seja, a relação entre família e os menores, há de se esclarecer que o Capítulo que se segue a este, adentrará mais profundamente a questão, o que torna a exposição deste tópico apenas introdutória.

De acordo com o artigo 226 da Constituição Federal Brasileira, a família é a base da sociedade e por isso tem especial proteção do Estado. A convivência humana se estrutura nas diversas células familiares que compõem a comunidade social e política do Estado. Assim sendo, o Estado acaba por se encarregar de amparar e aprimorar a família. ${ }^{54}$

Deste modo, não há que existir qualquer questionamento a respeito da importância do instituto e de sua consequente proteção. Entretanto, isso não impede que se critique o formato e a dimensão em que o poder familiar é imposto aos seus membros menores.

O modelo de família romano, ou seja, patriarcalista já há muito é alvo de críticas da doutrina e jurisprudência, vez que consistia em um poder sem limite dos pais em relação aos seus filhos. Inclusive, JOSÉ DE FARIAS TAVARES, nos ensina que "entre quase todos os povos antigos, tanto do Ocidente quanto do Oriente, os filhos durante a menoridade, não eram considerados sujeitos de direito, porém, servos da autoridade paterna" ${ }^{55}$.

Certo é, que esse modelo foi sendo transformado ao longo da história e, hoje, apesar de ainda, em casos concretos isolados, demonstrar alguns pontos em comum, mostra-se em sua esmagadora maioria distinto.

A ideia que permeia o poder familiar, decorrente da formação de uma família, nos dias de hoje é que trata-se de um dever jurídico e, não mais de um direito dos pais em relação aos seus filhos. Sob esta égide, ORLANDO GOMES destaca:

\footnotetext{
${ }^{54}$ MADALENO, Rolf, 1954 - Curso de direito de família/Rolf Madaleno - 6. ed. rev., atual. e ampl. Rio de Janeiro: Forense, 2015. p. 35.

${ }^{55}$ TAVARES, José de Farias. Direito da Infância e da Juventude. Belo Horizonte: Del Rey, 2001, p. 46
} 
Só recentemente se veio a compreender que o poder atribuído ao pai deve ser exercido no interesse do filho, abrandando-se, nos costumes e na lei, jugo paterno. Entende-se, na atualidade, que os poderes outorgados aos pais têm como medida o cumprimento dos deveres de proteção do filho menor. $\mathrm{O}$ instituto perdeu sua organização despótica inspirada no direito romano, deixando de ser um conjunto de direitos do pai sobre a pessoa dos filhos, amplos e ilimitados, para se tornar um complexo de deveres. ${ }^{56}$

No entanto, a doutrina não é unanime ao declarar o modelo jurídico no qual se encaixa o poder familiar. ANA CAROLINA BROCHADO TEIXEIRA, defende que o poder familiar está inserido na categoria de poder-dever jurídico, uma vez que esse poder decorreria de uma atribuição de competência do Estado, visando o beneficio de outrem. ${ }^{57}$

Destarte, a autora defende em seu livro a respeito de autoridade parental:

Assim, ainda subsiste a noção de poder-dever, mas não no sentido contraposto, de credito e debito. A perspectiva, neste caso, eh investida. Na autoridade parental, tanto o poder quanto o dever são dirigidos as mesmas pessoas: os pais, que devem usa-los para a concreção do Principio do Melhor Interesse da Criança e do Adolescente. ${ }^{58}$

Independentemente do modelo jurídico no qual o poder familiar se adequa, fato é que não se questiona que um dos pilares desse dever é a proteção e educação da criança e do adolescente. ${ }^{59}$ Logo, percebe-se que nos dias atuais, afasta-se cada vez mais da ideia de filhos submissos aos pais de maneira irrestrita ao passo que aproxima-se da autonomia individual do menor aliado com proteção familiar.

A figura do pátrio poder foi transformada em um poder familiar consubstanciado em uma função educativa e comprometida a promover as potencialidades do menor ${ }^{60}$. A relação existente entre pais e filhos pode ser

\footnotetext{
${ }^{56}$ GOMES, Orlando. Direito de família. Rio de Janeiro: Forense, 1996. p. 367

${ }^{57}$ TEIXEIRA, Ana Carolina Brochado. Família, guarda e autoridade parental. Rio de Janeiro: Renovar, 2005. p. 97.

${ }^{58}$ Idem.

59 SECO, Thaís. A autonomia da criança e do adolescente e suas fronteiras: capacidade, família e direitos da personalidade. 2013. Rio de Janeiro. 175 p. Dissertação (Mestrado em Direito) Universidade do Estado do Rio de Janeiro., p. 28.

${ }^{60}$ PERLINGIEREI, Pietro. O direito civil na legalidade constitucional. Rio de Janeiro: Renovar, 2008, p. 999.
} 
equiparada a uma via de mão dupla, como bem alerta LUIZ EDSON FACHIN ${ }^{61}$, posto que se trata da máxima expressão do principio da solidariedade familiar.

Não obstante esse ciclo de mudanças pelo qual o poder familiar passou, resta-se inquestionável a sua existência como força cerceadora de liberdade, ainda que com outro fim, não mais meramente instrumental e sim em prol do desenvolvimento do menor e com a finalidade de atender o princípio de seu melhor interesse ${ }^{62}$. Esse poder se manifesta em duas esferas: patrimonial e pessoal. A esfera pessoal na qual o poder familiar se faz presente engloba o sustento que é devido, a guarda e a educação. ${ }^{63}$

Em contrapartida, na esfera patrimonial, ORLANDO GOMES aponta: "incumbe aos pais administrar os bens dos filhos sob pátrio-poder, assistindolhes o direito de usar e fruir esses bens". ${ }^{64}$ Destaca-se que tanto a administração quanto o usufruto são limitadas pela proteção dos interesses do filho. Logo, não há que se falar em livre gestão em relação aos bens, pois que a lapidação do patrimônio é vedada, sob pena de ação de responsabilidade em face dos pais ou dos tutores que agirem em tal intuito, com culpa. ${ }^{65}$

Diante da dimensão e importância do poder familiar exercido sob a vida dos filhos menores, torna-se evidente a necessidade de controle por parte do Estado, ainda que observados seus limites, realçando mais a ideia de vulnerabilidade do infante, que será objeto de apreciação mais aprofundada no próximo capítulo deste estudo. A partir daí surge a possibilidade de destituição do poder familiar quando este está em desconformidade com o melhor interesse da criança e do adolescente.

Conclui-se que a mera existência da autoridade parental, já possui o condão, devido a sua natureza, de limitar a autonomia da criança, em razão de ser

\footnotetext{
${ }^{61}$ FACHIN, Luiz Edson. Elementos críticos do direito de família. Rio de Janeiro: Renovar, 1999, p. 245.

${ }^{62}$ TEPEDINO, Gustavo. A disciplina da guarda e a autoridade parental na ordem civil-constitucional. Revista Trimestral de Direito Civil, v. 17, n. 5, p.41

${ }^{63}$ Artigo 22 da Lei 8.069/90: "Art. 22. Aos pais incumbe o dever de sustento, guarda e educação dos filhos menores, cabendo-lhes ainda, no interesse destes, a obrigação de cumprir e fazer cumprir as determinações judiciais".

${ }^{64}$ GOMES, Orlando. Direito de Família. Rio de Janeiro: Forense, 1996. p. 375

${ }^{65}$ SECO, Thaís. A autonomia da criança e do adolescente e suas fronteiras: capacidade, família e direitos da personalidade. 2013. Rio de Janeiro. 175 p. Dissertação (Mestrado em Direito) Universidade do Estado do Rio de Janeiro., p. 30.
} 
dos pais, o poder de gerir o patrimônio dos pequenos bem como de prover sua educação, transmitir valores e conduzir suas escolhas.

Vale dizer, contudo, que embora a autoridade parental tenha o condão de limitar a autonomia de seus filhos menores, ela não a exclui totalmente, já que por vezes os pais podem entender que seus filhos já possuem discernimento para tomar aquela decisão em específico. Sendo assim, preceitua RENATA MULTEDO que: “à luz dos princípios constitucionais, há de se encontrar o equilíbrio entre o exercício dos direitos fundamentais dos filhos e autoridade parental dos pais, de modo a concretizar a liberdade da criança e do adolescente no processo educacional",66.

A necessidade de proteção, levando-se em consideração a vulnerabilidade da criança e do adolescente, é inegável. Todavia, os limites do poder familiar ainda são questionáveis, já que deveras extensos, embora estejamos cada vez mais afastados do modelo patriarcalista.

Um viés que aponta para o caminho da solução é encontrado na fala do doutrinador GUSTAVO TEPEDINO quando diz: "na medida em que, gradualmente, no curso deste processo, os filhos adquiram aptidão para valorar e tomar decisões, a ingerência dos pais deve diminuir, de modo a incentivar o exercício autônomo de escolhas existenciais",67.

\subsection{Aparato legislativo e jurídico em prol da proteção da criança e do adolescente e suas contradições.}

Como exposto ao longo deste capítulo, a condição de vulnerabilidade dos menores, eu seu maior ou menor grau, é entendida como inequívoca no direito brasileiro. Como conseguinte, os três poderes da federação buscaram e, ainda buscam, criar ferramentas de proteção em relação as esses indivíduos, tendo em vista a fase sensível de formação em que se encontram.

\footnotetext{
${ }^{66}$ MULTEDO, Renata Vilela. Liberdade e família: Limites para intervenção do Estado nas relações conjugais e parentais. Rio de Janeiro: Processo, 2017. p. 134.

67 TEPEDINO, Gustavo. A tutela constitucional da criança e do adolescente. In: Temas de direito civil. Rio de Janeiro: Renovar, 2009, p. 211-212, tomo 3.
} 
Sob este enfoque, o direito brasileiro passa a ser composto por uma série de princípios e normas que visam proteger o infante, sempre sob a ótica do principio da dignidade da pessoa humana ${ }^{68}$, presente no artigo $1^{\circ}$, III da Carta Magma e reafirmado no caput do artigo $5^{\circ}$.

Cabe lembrar que por se tratar de assunto de interesse público, não obstante o principio da não intervenção que norteia o direito de família ${ }^{69}$, a atuação do Estado na vigilância dessa proteção, quando delegada, é atuante e frequente (ex vi artigo $5^{\circ}$ do Estatuto da Criança e do Adolescente). Assim realça THAÍS SÊCO:

Quer dizer, se todas as pessoas devem ser protegidas pela sociedade, i.e., pelo Estado nos aspectos de sua humanidade, a proteção sobre a criança e o adolescente há muito não prescinde da interferência no próprio caráter privado das famílias, pois a forma como uma criança e um adolescente são tratados, ainda que no âmbito estritamente privado, é questão de interesse público. ${ }^{70}$

Firmado esse entendimento a respeito da necessidade de proteção do menor de idade, influenciado pela Declaração Universal dos Direitos das Crianças de 1959 e sob a ótica do principio da dignidade humana, o poder constituinte institui o artigo 227 na Carta Magma, objeto de mudança legislativa em 2010, na qual fora incluído também os jovens, consolidando em seu caput os seguintes termos: "É dever da família, da sociedade e do Estado assegurar à criança, ao adolescente e ao jovem, com absoluta prioridade, o direito à vida, à saúde, à alimentação, à educação, ao lazer, à profissionalização, à cultura, à dignidade, ao respeito, à liberdade e à convivência familiar e comunitária, além de coloca-los a salvo de toda forma de negligência, discriminação, exploração, violência, crueldade e opressão".

\footnotetext{
${ }^{68}$ Este princípio é entendido como um macroprincipio, se sobrepondo aos demais. Ingo Wolfgang Sarlet o traduz como: "o reduto intangível de cada indivíduo e, neste sentido, a última fronteira contra quaisquer ingerências externas. Tal não significa, contudo, a impossibilidade de que se estabeleçam restrições aos direitos e garantias fundamentais, mas que as restrições efetivadas não ultrapassem o limite intangível imposto pela dignidade da pessoa humana" (Sarlet, Ingo Wolfgang. A eficácia dos direitos fundamentais. 5 ed. Porto Alegre: Livraria do Advogado, 2005. p. 124).

${ }^{69}$ Artigo 1.513 do Código Civil: "é defeso a qualquer pessoa de direito público ou direito privado interferir na comunhão de vida instituída pela família”.

${ }^{70}$ SECO, Thaís. A autonomia da criança e do adolescente e suas fronteiras: capacidade, família e direitos da personalidade. 2013. Rio de Janeiro. 175 p. Dissertação (Mestrado em Direito) Universidade do Estado do Rio de Janeiro., p. 31.
} 
A redação do caput do artigo 227 trouxe para o direito, com status de princípio constitucional, o então chamado princípio do melhor interesse da criança e do adolescente. Imperioso esclarecer que o referido princípio encontrase positivado em diversos outros dispositivos, como por exemplo, no ECA em seus artigos $3^{\circ}$ e $4^{\circ}$ e no Código Civil em seus artigos 1.583 e 1.584 , os quais tratam da guarda durante o poder familiar.

Visando a efetivação do aludido princípio constitucional, o Superior Tribunal de Justiça chega a entender inclusive, que não é cabível qualquer alegação de nulidade processual, durante um procedimento de adoção, mesmo se suscitada pelo Ministério Público, quanto este tiver sido realizado de acordo com os parâmetros de proteção do menor. ${ }^{71}$

Os parágrafos subsequentes ao caput do mencionado dispositivo constitucional trazem para o ordenamento jurídico, o principio da tutela integral da criança e do adolescente consubstanciado em todas as estruturas políticas necessárias aos menores.

Como pode ser notado com clareza, o sistema jurídico brasileiro é coberto por uma série de princípios e normas que tornam cada vez mais evidentes a vulnerabilidade do menor e suas consequentes necessidades especiais, afastando de modo considerável uma equiparação à condição jurídica ocupada pelos maiores.

Todavia, retoma-se à questão já anteriormente criticada, qual seja a intensa imposição de condição de vulnerável e ausência de discernimento dos tidos como incapazes, sem que isso seja uma conclusão individual. Uma vez que não se analisa profundamente cada caso, os princípios supramencionados se insurgem de maneira irrestrita e, muitas vezes, acabam não alcançando seu objetivo principal.

Vê-se, portanto, com frequência, a sobreposição do regime de incapacidades em prol do objetivo principal dos princípios mencionados.

\footnotetext{
${ }^{71}$ TARTUCE, Flávio. Direito civil, v. 5: Direito de Família/Flávio Tartuce. - 12 ed.rev., atual e ampl. Rio de Janeiro: Forense, 2017. p. 24
} 
Alcança-se em nome dos aludidos princípios, resultados distintos do que por eles pretendidos, devido à ausência de sensibilidade ao se analisar o caso concreto.

Com o intuito de ilustrar o defendido, é válido observar um caso julgado pelo Tribunal da Flórida, nos Estados Unidos da América, no ano de 1993 conhecido como Kinglsey x Kinglsey ${ }^{72}$. Gregory Kinglsey, menino de 12 anos de idade, ingressou com uma ação judicial requerendo que o poder familiar fosse destituído dos seus pais biológicos.

Isso se deu em razão de Gregory ser alvo de abuso físico praticado por seu pai biológico e, por ter que conviver com o alcoolismo de ambos os genitores do pequeno. Inclusive, tal situação fez com que o menino fosse aos 8 (oito) anos de idade encaminhado provisoriamente para uma família substituta, a qual queria permanecer.

Entretanto, ao ingressar em juízo requerendo que fosse adotado de maneira definitiva pela família que o acolheu e, como consequência seus pais biológicos perdessem o poder familiar, sua mãe biológica alegou a incapacidade do menor em postular em juízo.

Não obstante Gregory tenha vencido em primeira instância, o Tribunal da Florida reformou tal decisão por acolher o argumento materno. No caso em comento, nota-se a que ponto o regime de incapacidades se sobressai ao efetivo principio de melhor interesse da criança.

Curioso notar essa relação paradoxal existente entre os princípios de proteção do menor e o regime de incapacidade vez que a "proteção integral" e o "melhor interesse" foram positivados devido a uma vulnerabilidade existente e, os comentados princípios por vezes não são postos em prática justamente pelo motivo que os criou, pela suposta incapacidade.

Nesse sentido, imperioso destacar a conclusão que chega THAÍS SECO:

O sistema jurídico de proteção à criança e ao adolescente está repleto de suposições, seja sobre sua capacidade e discernimento para tomar decisões e interferir no curso de

\footnotetext{
${ }^{72}$ Kinglsey v Kinglsey. Disponível em <https://en.wikipedia.org/wiki/Gregory_Kingsley>. Acessado em 20 de abril de 2018.
} 
sua própria história, seja com relação ao que pode ou não ser prejudicial para o seu desenvolvimento psíquico e moral. Contrapostas aos fatos, essas suposições se transformam em contradições em que, a pretexto de proteger a criança e o adolescente, seus interesses são ignorados e eles mesmos nada podem fazer a respeito ${ }^{73}$.

Diante do que se expõem não pairam dúvidas a respeito do caráter insatisfatório do modelo jurídico tal como é vivenciado nos dias de hoje. A autonomia da criança e o do adolescente vem sendo restringida sem se observar, contudo, o resultado ao qual se quer chegar e é garantido constitucionalmente.

Sendo observadas essas críticas por parte dos doutrinadores, o movimento jurídico em prol de uma maior autonomia para as crianças vem ganhando cada vez mais força. JOÃO BAPTISTA VILELLA, em um evento promovido pela Faculdade de Direito da UFMG em setembro de 2010 destacou com maestria:

Não adianta fixar limites etários mais variados e extrair conclusões "de costas para realidade". Há pessoas que aos 16 possuem mais maturidade que outras aos 40 . O direito não pode aspirar a uma perfeição absoluta, não pode se render a essa outra tentação de exatidão. Mas também não pode "brincar" com isso. O sistema é falho. ${ }^{74}$

Embora não se possa negar que as criticas são voltadas, em sua esmagadora maioria, para o regime de incapacidades como um todo, deve-se observar o fato da problemática maior concentrar-se em um regime de absolutamente incapazes. Isso deve ao fato da jurisprudência e da própria legislação estarem trazendo consigo uma abertura maior no que tange o exercício da autonomia dos jovens compreendidos entre 16 e 18 anos.

Diante da problemática apresentada, passa-se a explorar mais profundamente, tema já introduzido no presente Capítulo que, de sua maneira, limita a autonomia da criança e do adolescente e, concomitantemente é responsável de forma substancial pelo seu pleno desenvolvimento e posterior capacidade, o núcleo familiar. Sob este enfoque, se analisará também o motivo pelo qual o Estado acaba por interferir nas relações familiares, observando-se, contudo, as fronteiras para isso.

\footnotetext{
${ }^{73}$ SECO, Thaís. A autonomia da criança e do adolescente e suas fronteiras: capacidade, família e direitos da personalidade. 2013. Rio de Janeiro. 175 p. Dissertação (Mestrado em Direito) - Universidade do Estado do Rio de Janeiro., p. 31.

${ }^{74}$ VILLELA, João Baptista. O fim das menoridades. Disponível em <youtube.com>, acesso em 19 de abril de 2018.
} 


\section{Capítulo II - Triangulação visando a proteção e os interesses das crianças e dos adolescentes: Estado, família e autonomia.}

\subsection{Constitucionalização da família brasileira: a recepção de princípios constitucionais na relação existente entre os membros da família.}

O modelo patriarcalista que vigorou no Brasil até o século XIX, fez com que somente fossem reconhecidas e tuteladas à época, famílias provenientes do matrimônio. No entanto, não é correto afirmar que somente a família patriarcal e matrimonial era a existente no Brasil, pelo contrário, o país sempre fora marcado pela diversidade, sendo composto por diversos outros modelos ${ }^{75}$ dos quais não eram reconhecidos ou tutelados.

Não obstante a existência da comentada variedade, somente na década de 70 a hegemonia do modelo tradicional de família tal qual nos era apresentado começou a ser questionada ${ }^{76}$. A partir daí, iniciou-se o processo de reconhecimento de diversos modelos familiares existentes no Brasil.

Somente com o advento da Constituição de 1988 novas formas de reuniões familiares foram finalmente oficialmente reconhecidas, tanto assim o é, que apareceu no texto constitucional, pela primeira vez, as uniões estáveis e a família monoparental (art. 226, parágrafos 3 e 4$)^{77}$.

Importante ressaltar que esses dois modelos citados no texto constitucional são meramente exemplificativos, cabendo, portanto, proteção do Estado em outros tipos de reuniões familiares, como por exemplo, a união

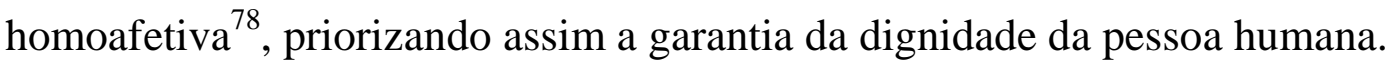

Ademais, podem ser destacadas ainda, diversas outras modificações trazidas com a Carta Magma de 1988 nas relações familiares que possuem como

\footnotetext{
${ }^{75}$ CORRÊA, Mariza. Repensando a família patriarcal brasileira. In: ALMEIDA, Angela (Org). Colcha de retalhos: estudos sobre a família no Brasil. São Paulo: Brasiliense, 1982.

${ }^{76}$ MULTEDO, Renata Vilela. Liberdade e família: limites para intervenção do Estado nas relações conjugais e parentais. Rio de Janeiro: Processo, 2017. p. 27.

${ }^{77}$ Ibid. p. 32.

${ }^{78}$ MATOS, Ana Carla Harmatiuk. União entre pessoas do mesmo sexo: aspectos jurídicos e sociais. Belo Horizonte: Del Rey, 2004.
} 
intuito a ampliação de direitos e deveres em prol da garantia da dignidade da pessoa humana, como por exemplo, a equiparação entre os filhos (art. 227, parágrafo 6) e a previsão de intervenção estatal na família com o objetivo de proteger seus membros (artigo 226, parágrafo 8), assunto que será tratado mais profundamente ao longo deste estudo.

Deve ser observado que com a CRFB de 88 e suas consequentes modificações normativas constitucionais, ocorreu o fenômeno da recepção de princípios importantes para dentro da família, ou seja, na relação entre membros e, não só, na relação da família como um todo e o Estado, vez que agora busca-se a satisfação da dignidade da pessoa humana nas relações interpessoais de seus membros, predomina a igualdade substancial e está fixada como norte a solidariedade familiar ${ }^{79}$. Sendo assim, destaca RENATA MULTEDO:

Após um longo período de dogmas e preconceitos, a família fundada no casamento, preservada e valorizada a qualquer custo como instituição acima dos interesses de seus integrantes, cede lugar a uma família que passa a ser vista como um núcleo intermediário de desenvolvimento da personalidade dos filhos e de promoção da dignidade de seus membros. ${ }^{80}$

Com a inserção de tais princípios constitucionais, tornou-se evidente a modificação no olhar voltado para as crianças e adolescentes dentro da família que, agora, passam a ser objeto de proteção e a elas deve ser garantido um espaço de desenvolvimento de sua personalidade, onde os pais devem lhe prover educação visando sua emancipação ${ }^{81}$.

Essa concepção de igualdade trazida pelo princípio da dignidade da pessoa humana foi fundamental para a modificação do conceito de poder familiar, tema já introduzido no primeiro Capítulo, com nos relata PIETRO PERLINGIEREI:

O esquema do Pátrio Poder, visto como poder-sujeição, está em crise, porque não há dúvidas de que, em uma concepção de igualdade, participativa e democrática da comunidade familiar, a sujeição, entendida tradicionalmente, não pode continuar a realizar o mesmo papel. A relação educativa não é mais entre o sujeito e um objeto, mas

\footnotetext{
${ }^{79}$ TEPEDINO, Gustavo. A disciplina da guarda e a autoridade parental na ordem civil-constitucional. Revista Trimestral de Direito Civil, v. 17, n. 5, 2004, p.34.

${ }^{80}$ MULTEDO, Renata Vilela. Liberdade e família: limites para intervenção do Estado nas relações conjugais e parentais. Rio de Janeiro: Processo, 2017. p. 35.

${ }^{81}$ PERLINGIERI, Pietro. O direito civil na legalidade constitucional. Rio de Janeiro: Renovar, 2008, p. 258.
} 
uma correlação de pessoas, onde não é possível conceber um sujeito subjugando o outro. ${ }^{82}$

Logo, é inequívoca a importância do processo de constitucionalização da família brasileira para compreender a prevalência existente nos dias atuais pela autonomia dos membros da família e da própria instituição familiar em si.

Isso porque, todas essas mudanças nada mais visam que a satisfação do princípio máximo da dignidade da pessoa humana, norteador da Carta Magma de 88, que tem como um de seus fundamentos a liberdade individual. Sob esta ótica, entende-se que a única intervenção coerente com o ordenamento jurídico constitucional, é aquela que age dentro dos limites da defesa e interesses da pessoa sobre quem se intervém ${ }^{83}$.

A partir dessa visão, cabe expor duas concepções atuais a respeito da seio familiar, provenientes dessa constitucionalização do direito de família para que assim, adentre-se, finalmente, no ponto central deste Capítulo, qual seja, a relação triangular entre criança e adolescente, família e Estado.

\subsubsection{Família-instrumento e família democrática.}

Como esclarecido em outra oportunidade (item 1.4), a família é um dos pilares da sociedade. Assim sendo, quaisquer mudanças na "família" acarretam em modificações sociais, tanto a curto como longo prazo. Isso porque quanto mais famílias democráticas, maior é o fortalecimento da democracia no espaço político público. ${ }^{84}$ Vale dizer que a recíproca é verdadeira, posto que quando se tem um modelo de família predominantemente autoritário, tende-se a ter igualmente um Estado autoritário, uma vez que só este modelo de Estado impõe

\footnotetext{
${ }^{82}$ PERLINGIERI, Pietro. Perfis de direito civil. 3 ed. Traduzido por Maria Cristina de Cicco. Rio de Janeiro: Renovar, 2007, p. 258.

${ }^{83}$ MULTEDO, Renata Vilela. Liberdade e família: limites para intervenção do Estado nas relações conjugais e parentais. Rio de Janeiro: Processo, 2017. p. 39.

84 BODIN DE MORAES, Maria Celina. A família democrática. In: Na medida da pessoa humana: estudos de direito civil-constitucional. Rio de Janeiro: renovar, 2010, p. 214.
} 
sobre uma pessoa a obrigação desta se sujeitar perante a vontade de seus pais de maneira irrestrita. ${ }^{85}$

Em contrapartida, a família pode ser entendida como um instrumento a medida que esta objetiva a realização pessoal de seus membros, que por sua vez, compõe a sociedade. Ou seja, uma família que visa a promoção da autoestima de seus membros, que proporciona a fala para todos, que elimina o caráter hierárquico, faz com que a sociedade passe a ser mais democratizada.

MARIA CELINA BODIN DE MORAES defende que na família democrática "a tomada de decisão deve ser feita através da comunicação, através do falar e do ouvir" ${ }^{86}$. Por fim, sintetiza ANTHONY GIDDES a respeito do processo de democratização da família:

Só há uma história para contar sobre a família de hoje, e esta é de democracia. A família está se tornando democratizada, segundo modos que acompanham processos de democracia pública; e tal democratização sugere como a vida familiar poderia combinar escolha individual e solidariedade social. Os critérios são supreendentemente próximos. A democracia na esfera pública envolve igualdade formal, direitos individuais, discussão pública de problemas isenta de violência e autoridade negociada em vez de dada por tradição. A família democratizada partilha essas características, algumas das quais já estão protegidas no direito nacional e internacional. A democratização no contexto da família implica igualdade, respeito mútuo, autonomia, tomada de decisão através da comunicação e resguardo da violência. Grande parte das mesmas características fornece também um modelo para os relacionamentos pais-filhos. Os pais vão, é claro, continuar reivindicando autoridade sobre os filhos, e com razão; mas esta será mais negociada e aberta que antes ${ }^{87}$.

Não obstante a existência de um diálogo mais aberto e de uma troca significativamente maior, a autoridade parental não se tornou vazia ou desnecessária, ao contrário. Deve-se sempre ter em mente o papel dos pais na criação de seus filhos, levando-se em conta a máxima convivência e o afeto envolvido, o que torna indiscutível o fato deles serem os maiores conhecedores de sua prole e, por esta razão, saberem, na maioria das vezes, o que lhe serve de melhor ou pior forma.

\footnotetext{
${ }^{85}$ SECO, Thaís. A autonomia da criança e do adolescente e suas fronteiras: capacidade, família e direitos da personalidade. 2013. Rio de Janeiro. 175 p. Dissertação (Mestrado em Direito) Universidade do Estado do Rio de Janeiro., p. 89.

${ }^{86}$ BODIN DE MORAES, Maria Celina. Op. Cit.,, p. 213.

${ }^{87}$ GIDDENS, Anthony. A Terceira via: reflexões sobre o impasse político atual e o futuro da social democracia. Tradução: Maria Luiza X. de A. Borges. Rio de Janeiro: Record, 1999, p. 103.
} 
No entanto, podem vir a surgir situações nas quais o Estado deva se manifestar para garantir que o melhor interesse da criança e do adolescente esteja sendo realmente preservado, sem que para isso haja uma violação à democracia e ao ambiente plural de um Estado democrático de direito.

\subsection{Intervencionismo Estatal versus Autoridade Parental.}

Como analisado anteriormente (item 1.3.3), a questão da maturidade e discernimento do menor de idade é muito mais complexa do que possa parecer. Isso porque não se pode negar a existência de dúvidas legítimas quanto ao real discernimento cabível a um individuo que está em plena fase de desenvolvimento e, consequente formação.

Embora possa ser entendido por grande parte da doutrina que o ser humano é por si só vulnerável, deve-se compreender que as crianças e os adolescentes por uma série de fatores, mostram-se, em sua grande maioria, mais vulneráveis ainda, razão pela qual necessitam de representação ou assistência no mundo jurídico e pessoal.

Ao mesmo tempo, contudo, não se deve deixar de observar situações nas quais o infante tenha discernimento para tomar certas decisões, ou ainda, situações em que ele não mostre maturidade suficiente, mas por serem decisões de cunho extremamente pessoal, não parece cauteloso que sejam tomadas por outras pessoas naquele dado momento.

Como já é sabido, doutrina e legislação entenderam por bem atribuir ao poder familiar a tomada de decisões referentes a vida desses tido como incapazes, mesmo que temporariamente, como uma forma de garantir o melhor para o infante. Logo, acredita-se que a tomada de decisões relativas ao menor de idade deva ser feita de maneira heterônoma, em sua grande maioria das vezes, devido a esta realçada vulnerabilidade.

É justamente sob este enfoque que recai a justificativa para existência da possibilidade de intervenção estatal no âmbito da família, a medida que pela função protetiva do Estado, este tem o dever de "desconfiar" da forma como está 
sendo exercido o poder familiar. ${ }^{88}$ Isso porque quando se toma uma decisão fazendo uso de sua autonomia, os ônus assim como os bônus de tal decisão recaem sobre a si mesmo. Entretanto, quando se toma uma decisão em nome de outrem, deve existir por parte do Estado a preocupação perante aquele o qual vai recair as consequências da tomada de decisão heterônoma.

Ademais, não se pode ignorar o fato de ser na família que a criança vai encontrar suas maiores referências, construir seu caráter e encontrar um espaço para desenvolver sua personalidade. A responsabilidade atribuída aos entes familiares é muito maior do que se possa exprimir em meras palavras. Por esta razão, não se mostra absurda a ideia do Estado poder intervir observando limites, nas decisões familiares e, assim, acabar limitando a autonomia do poder parental nas suas devidas proporções.

Deve-se ter cautela ao analisar esse interesse público quanto as crianças e aos adolescentes, uma vez que não trata-se aqui de uma transposição de direito privado para o público, ao contrário, o Direito de Família continua sendo um dos direitos mais íntimos que possa existir. Sendo assim, não se pode olvidar dos limites inerentes a esta intervenção em comento.

Essa questão torna-se mais sensível quando nos deparamos com a nossa inserção em uma sociedade democrática, onde deve ser preservado o pluralismo. Logo, de um lado temos o poder-dever familiar tomando decisões a respeito das crianças e dos adolescentes de acordo com as suas convicções e valores, garantindo assim o pluralismo social, mas por outro lado, temos o Estado cumprindo seu papel protecionista analisando as decisões quanto ao senso comum e, muitas vezes, positivando esse senso, vinculando as decisões parentais $^{89}$.

\footnotetext{
${ }^{88}$ SECO, Thaís. A autonomia da criança e do adolescente e suas fronteiras: capacidade, família e direitos da personalidade. 2013. Rio de Janeiro. 175 p. Dissertação (Mestrado em Direito) Universidade do Estado do Rio de Janeiro., p. 83.

${ }^{89}$ Assim o é, por exemplo, quando se trata de relação sexual de menores de 14 anos. O Estado positivou no Código Penal o crime denominado estupro de vulnerável que consiste na prática de ato sexual com menores de 14 anos. Ou seja, mesmo que os pais deem seu consentimento e autorizem uma menina de 13 anos a ter relações sexuais, ela assim não o poderá fazer em razão da proibição estatal.
} 
O controle do Estado não é somente no sentido de restringir a autonomia da criança e do adolescente, ao contrário, pode também avaliar o discernimento do infante chegando a conclusão que este tem autonomia para tomada de certa decisão, ao contrário do que entende seus pais.

A intervenção estatal ainda pode ocorrer por outras razões, como por exemplo, o Estado crer que os pais estão colocando em risco seus filhos; divergência entre os próprios pais do menor de idade quanto à assuntos relativos a estes, ou entre as crianças e adolescentes e seus pais. A partir desse contexto, cumpre analisar a intervenção estatal no exercício da autoridade parental.

Sabe-se que a autonomia parental é a regra e que as decisões heterônomas por parte do Estado são as exceções e essas só devem ser feitas visando o melhor interesse do vulnerável. Existem decisões que somente os pais em conjunto com a criança podem tomar, seja pelo vínculo afetivo existente entre eles, seja pela proximidade que ambos têm um com outro, o que permite que nada nem ninguém os conheça de forma mais profunda ${ }^{90}$.

Sendo assim, não restam dúvidas que essas decisões do Estado em assuntos familiares não podem se dar de maneira irrestrita, havendo limitações a serem observadas e respeitadas com o intuito de evitar exageros ${ }^{91}$.

Agir em nome no melhor interesse da criança e do adolescente, pode se mostrar muito mais difícil do que parece, uma vez que "quando se trata de proteger um melhor interesse de alguém, se tratará de ponderar qual seja esse interesse em face dos outros interesses que tem" ${ }^{\text {"92 }}$.

Essa avaliação por parte do Estado pode ser alvo de severas críticas quando vai de encontro com uma decisão tomada pela autoridade parental, uma

\footnotetext{
${ }^{90}$ SECO, Thaís. A autonomia da criança e do adolescente e suas fronteiras: capacidade, família e direitos da personalidade. 2013. Rio de Janeiro. 175 p. Dissertação (Mestrado em Direito) Universidade do Estado do Rio de Janeiro., p. 115.

${ }^{91}$ MENEZES, Joyceane Bezerra de; VILELA MULTEDO, Renata. A autonomia ético-existencial do adolescente nas decisões judiciais sobre o próprio corpo e a heteronomia dos pais e do Estado no Brasil. Revista de Direito Administrativo \& Constitucional, Belo Horizonte, v. 13, n.58, jan/fev, 2016 Apud VILELA MULTEDO, Renata. Liberdade e família: limites para intervenção do Estado nas relações conjugais e parentais. Rio de Janeiro: Processo, 2017, p. 121.

92 SECO, Thaís. A autonomia da criança e do adolescente e suas fronteiras: capacidade, família e direitos da personalidade. 2013. Rio de Janeiro. 175 p. Dissertação (Mestrado em Direito) Universidade do Estado do Rio de Janeiro., p. 95.
} 
vez que, repita-se à exaustão, é quem convive diariamente com o individuo e tem maior capacidade de avaliar seu discernimento para determinado ato.

Um exemplo clássico de atuação do Estado no exercício da autoridade parental é o de Laura Dekker, uma menina de 13 anos de idade, nascida na Holanda que decidiu por conta própria dar a volta ao mundo sozinha em seu veleiro. O objetivo da menina consistia em ser a pessoa mais jovem do mundo a realizar tal aventura. Após conseguir o consentimento de seus pais, o Estado holandês não permitiu a travessia sob o argumento de estar cumprindo o melhor interesse da pequena. Inclusive, os pais da menina acabaram por perder a custódia da filha por um lapso temporal, sob a justificativa que não estariam preservando a integridade psicofísica da menor. Ao fim do processo judicial, restou-se decidido que caberia aos pais tal decisão e não ao Estado Holandês ${ }^{93}$. E, por esta razão, Laura realizou seu sonho e aos 16 anos tornou-se a menina mais nova a dar a volta ao mundo. O caso narrado representa a típica situação em que a adolescente possuía discernimento para o ato, mas carecia de capacidade jurídica para exercê-lo ${ }^{94}$.

Como bem defende THAÍS SÊCO, essa triangulação existente entre Estado, família e menor faz com que não se possa afirmar a existência de uma autonomia propriamente dita em relação aos pequenos. Isso porque só se poderia falar em autonomia quando se trata do "terceiro vértice ocupado pela própria criança e pelo próprio adolescente (...). Enquanto nos dois outros vértices tratase, não de autonomia, mas de heteronomia" 95 .

As decisões heterônomas do Estado não se restringem aos casos nos quais ele é provocado a atuar, dessa maneira, a intervenção estatal pode ocorrer de ofício, limitando o direito decisório das famílias sobre seus filhos e dos próprios filhos sobre as suas vidas, como é o caso das previsões legislativas. O exemplo

\footnotetext{
${ }^{93}$ KIEVT, Robin. "Dreams Scuppered for Dutch Sailor Girl”. BBC News, 28.08.2009. Disponível em <http://news.bbc.co.uk/2/hi/europe/8226196.stm>. Acessado em 25 de abril de 2018. Apud. SÊCO, Thaís. Por uma nova hermenêutica do direito da criança e do adolescente. Civilistica.com, Rio de Janeiro, v.3, n.2, p.4, ago/dez.2014.

${ }^{94}$ MULTEDO, Renata Vilela. Liberdade e família: limites para intervenção do Estado nas relações conjugais e parentais. Rio de Janeiro: Processo, 2017. p. 125.

${ }^{95}$ SÊCO, Thaís. Por uma nova hermenêutica do direito da criança e do adolescente. Civilistica.com, Rio de Janeiro, v.3, n.2, p.4, ago/dez.2014.
} 
capaz de ilustrar essa situação com muita clareza, já fora comentado anteriormente e, consiste na proibição de menores de 14 anos realizarem atos sexuais ${ }^{96}$, mesmo que haja consentimento de seus pais ou que seja o caso de pleno discernimento do infante para realização do ato.

Outro exemplo apto a ilustrar a intervenção estatal no poder decisório dos pais em relação ao desenvolvimento de seus filhos, é a questão da visitação avoenga, que a depender do caso em concreto é assegurada mesmo se não consentida pelos responsáveis da criança ou do adolescente. Pode-se citar ainda, diversos outros exemplos, como por exemplo, a inovação legislativa datada de 2014, trazendo a guarda compartilhada como regra na ausência de concordância entre os pais após a dissolução conjugal.

\subsubsection{Visitação avoenga: previsão legislativa objetivando a concretização do direito ao convívio familiar da criança e do adolescente.}

Como elucidado ao longo deste estudo, a CRFB atribuiu às crianças e aos adolescentes, uma série de direitos afim de que seus respectivos crescimentos e, consequente desenvolvimentos, fossem sendo realizados de maneira digna e democrática. Dentre inúmeros direitos de inquestionável relevância, cabe destacar no presente momento o "direito ao convívio familiar" extraído da redação do art. 227 da Carta Magma e delineado posteriormente pelo Estatuto da Criança e do Adolescente ${ }^{97}$.

Como bem define NELSON NERY JÚNIOR e MARTHA MACHADO, a convivência familiar apresenta-se como:

Uma estrutura valorativa em forma de pirâmide, que vai da base ao topo numa linha de crescente excepcionalidade, na medida em que a pirâmide se afunila: quando se discute onde a criança deve crescer e ser criada, na base está a família natural (entidade

\footnotetext{
${ }^{96}$ A realização de atos sexuais com crianças até 14 anos consiste em "estupro de vulnerável”, conduta tipificada no Código Penal Brasileiro através do art. 217-A. O STJ aprovou a Súmula 593 sobre o assunto na qual determinou: "o crime de estupro de vulnerável configura com a conjunção carnal ou prática de ato libidinoso com menor de 14 anos, sendo irrelevante o eventual consentimento da vítima para a prática do ato, experiência sexual anterior ou existência de relacionamento amoroso com o agente". ${ }^{97}$ Art. 19 do Estatuto da Criança e do Adolescente: "é direito da criança e do adolescente ser criado e educado no seio de sua família e, excepcionalmente, em família substituta, assegurada a convivência familiar e comunitária, em ambiente que garanta seu desenvolvimento integral.”. Disponível em <http://www.planalto.gov.br/ccivil_03/leis/18069.htm>. Acessado em 25 de abril de 2018.
} 
formada pelos pais biológicos); no topo, o abrigo da criança em instituição de acolhimento. (...) Na estrutura acima detalhada, quanto mais próximo ao cume, mais longe se estaria da situação ideal: a criação da criança pela sua família natural. ${ }^{98}$

A partir desse conceito, entende-se o convívio familiar como um direito essencialmente existencial $^{99}$ da criança em crescer ao lado de seus familiares, mantendo seus respectivos vínculos afetivos com a intenção de contribuir para seu desenvolvimento sadio. Sob esta linha de raciocínio, dúvidas não pairam quanto ao direito das crianças em conviverem com seus avós, importantes sujeitos na formação de um individuo.

Desta maneira, a Lei 12.398 de 28 de março de 2011 foi responsável pela positivação deste direito, qual seja, de visitação avoenga, acrescentando parágrafo único ao art. 1.589 do Código Civil de $2002^{100}$ e atribuindo nova redação ao inciso VII do art. 888 do então Código de Processo Civil de $1973^{101}$, vigente na época.

A produção legislativa sobre o assunto foi realizada sob forte influência da jurisprudência que já se consolidava por todo o território nacional. O período compreendido entre a promulgação da CRFB, ou seja, 1988 e 2011, ano de publicação da Lei 12.398, inúmeros conflitos a respeito da visitação avoenga foram ter seu desfecho no Poder Judiciário sem que houvesse uma norma específica sobre o tema. Os conflitos decorrerem a ainda decorrem de um clima de animosidade das mais variadas formas, como por exemplo, de pais que não consentem em conjunto sobre a visitação dos avós em relação aos seus filhos, de

\footnotetext{
${ }^{98}$ NERY JÚNIOR, Nelson; MACHADO, Martha de Toledo. O Estatuto da Criança e do Adolescente e o Novo Código Civil à luz da Constituição Federal: Princípio da Especialidade e Direito Intertemporal. Revista de Direito Privado, São Paulo, v.3, n.12, p 9-49, 2002.

${ }^{99}$ VILELA MULTEDO, Renata. Liberdade e família: limites para intervenção do Estado nas relações conjugais e parentais. Rio de Janeiro: Processo, 2017, p. 165.

${ }_{100}$ Art. 1.589, parágrafo único do Código Civil: "o direito de visita estende-se a qualquer dos avós, a critério do juiz, observados os interesses da criança ou do adolescente". Disponível em <http://www.planalto.gov.br/ccivil_03/_Ato2011-2014/2011/Lei/L12398.htm>. Acessado em 25 de abril de 2018.

${ }^{101}$ Art. 888, VII do Código de Processo Civil de 1973: "O juiz poderá ordenar ou autorizar, na pendência da ação principal ou antes de sua propositura: a guarda e a educação dos filhos, regulado o direito de visita quem no interesse da criança ou do adolescente, pode, a critério do juiz, ser extensivo a cada um dos avós". Disponível em < http://www.planalto.gov.br/ccivil_03/LEIS/L5869.htm>. Acessado em 25 de abril de 2018.
} 
pais separados que não permitem a visitação avoenga por parte dos avós maternos ou paternos, exclusivamente, dentro outras.

Nesse aspecto, antes da publicação da mencionada lei positivando o direito aqui tratado, o Tribunal do Rio Grande do Sul, assim como os demais do território nacional, já se posicionava na direção de assegurar o direito dos avós e dos pequenos sob o argumento de se tratar do melhor interesse da criança:

Agravo de Instrumento. Família. Relações de parentesco. Regulamentação de visitas dos avós. Atendimento do princípio da preponderância do interesse da criança. Deve ser preservada a situação que ocasiona bem-estar e maior estabilidade emocional e afetiva à criança, principalmente quando ausente demonstração de que o infante se encontra sob risco quando em companhia dos avós.

(Tribunal de Justiça do Rio Grande do Sul. Agravo de Instrumento n. 700366349884. Relator: Des. José Conrado de Souza Júnior, 7 Câmara Cível, Porto Alegre, Julgamento: 23.08.2010).

Não obstante a inequívoca importância de tal direito atribuído pelo Estado, não devem ser ignoradas pelo julgador as possíveis peculiaridades e nuances do caso concreto. Isso, pois, algumas vezes a ausência de concordância por parte dos pais em relação a visitação dos avós, pode ser fundamentada em argumentos relevantes. Por esta razão, independente de qualquer previsão normativa, deve-se prevalecer o principio do melhor interesse da criança.

Ao mesmo tempo que a visitação avoenga se mostra, na grande maioria das vezes, essencial para o desenvolvimento da criança, pode se estar diante de uma situação peculiar onde a interferência estatal baseada puramente na letra de lei, pode causar danos irreversíveis. Neste diapasão, o magistrado deve ficar sempre atento nas razões pelas quais os pais romperam o relacionamento com os avós, obstaculizando a relação destes com seus filhos.

Sob esta égide, alerta RENATA MULTEDO a respeito da importância do auxilio das equipes interdisciplinares, que objetivam "preservar a integridade psíquica da criança, não se criando mais uma hipótese legal que permita que a criança seja utilizada como instrumento para perpetuar o restabelecimento de um litígio ou mesmo a este auxiliar”. 102

\footnotetext{
${ }^{102}$ VILELA MULTEDO, Renata. Liberdade e família: limites para intervenção do Estado nas relações conjugais e parentais. Rio de Janeiro: Processo, 2017, p. 162.
} 
Vê-se, portanto, que a motivação do legislador foi pautada no melhor interesse da criança e, as decisões relativas aos casos concretos devem seguir essa égide. ${ }^{103} \mathrm{~A}$ visitação avoenga não deixa de ser uma inovação legislativa que interfere no exercício da autoridade parental em prol do interesse do menor, mas sob este aspecto, há de se considerar a ausência de um direito absoluto por parte dos avós ${ }^{104}$, vez que deve ser priorizado, em primeiro plano, os interesses e benefícios da parte vulnerável.

A questão torna-se crítica quando os pais do infante, em consenso, são contrários à visitação dos avós. Pois, como é sabido, em regra, ninguém melhor que os pais, para decidirem a respeito de seus próprios filhos quando estes não tem discernimento para determinado ato ou decisão, seja pela proximidade ou pelo afeto envolvido. Por isso, a intervenção estatal deve ser analisada com muita cautela nessas situações. RENATA MULTEDO, sobre isso defende:

\footnotetext{
${ }^{103}$ Importante trazer a baila, julgado recente do Tribunal de Justiça do Estado do Rio de Janeiro, no sentido de negar provimento ao recurso de uma avó que estava requerendo regulamentação de visitas em face da neta, sob o argumento de não ser a medida adequada a cumprir o melhor interesse da criança. Ementa: APELAÇÃO CÍVEL. REGULAMENTAÇÃO DE VISITAS DE AVÓ PATERNA. RELAÇÃO CONFLITUOSA COM A NETA. CONVIVÊNCIA QUE NÃO É IMPEDIDA PELA GENITORA. AVÓ QUE SE RECUSA A ACEITAR OUTRA FORMA DE VISITAÇÃO DIVERSA DA PRETENDIDA. OBSERVÂNCIA DO PRINCÍPIO DO MELHOR INTERESSE DO MENOR. IMPROCEDÊNCIA MANTIDA. 1. A hipótese é de ação de regulamentação de visitas proposta pela avó paterna, objetivando o reconhecimento do seu direito de visitação a menor impúbere, sua neta, que possui atualmente quinze anos. 2. A sentença rejeitou o pedido, ao fundamento de que a visitação na forma como requerida pela autora não atende ao melhor interesse da menor. 3. Consoante dispõe o parágrafo único do art.1.589 do CC, incluído pela Lei 12.398/11, os avós têm direito de visitar os netos, contudo o próprio parágrafo único faz a ressalva de que para se fixar tal direito, deve ser observado o interesse da criança ou adolescente, mantendo-se a prevalência do princípio da proteção integral, no qual deve se pautar qualquer decisão envolvendo menores. 4. O direito do menor à convivência familiar também encontra assegurado pelo art. 19 do ECA e art. 227 da Constituição Federal. 5. Na presente hipótese, pela leitura atenta do Estudo Social produzido, o relacionamento entre avó e neta revela-se conflituoso. 6. A mudança nas declarações autorais, acompanhada do Estudo Social elaborado pelas experts do juízo, demonstram a instabilidade emocional da recorrente, fator que configura obstáculo à convivência com a neta nos moldes requeridos na petição inicial. 7. Não obstante, impende salientar que a convivência entre avó e neta não é impedida pela apelada, uma vez que a adolescente tem livre acesso ao seu pai, momento em que poderia ocorrer a visitação avoenga, contudo essa forma de contato foi recusada pela própria apelante. 8. Em verdade, conforme já reconhecido nos autos pelo Ministério Público e pelo juízo a quo, a pretensão autoral revela-se um mero capricho, desprovido do desejo de fazer prevalecer o interesse da menor à convivência familiar. 9. Mantida sentença de improcedência do pedido autoral. 10. Desprovimento do recurso. (Tribunal de Justiça do Estado do Rio de Janeiro. Apelação n. 0023796-97.2014.8.19.0204. Relatora: Desembargadora Mônica Maria Costa Di Piero, Oitava Câmara Cível, Rio de Janeiro, Julgamento: 10/04/2018).

${ }^{104}$ TEIXEIRA, Ana Carolina Brochado. Direito de visitas dos avós. Revista Trimestral de Direito Civil. Rio de Janeiro, v. 10, p. 62-64, 2002.
} 
(...) não se deve presumir que os pais, quando em consenso e no exercício da autoridade parental, estejam agindo contra o melhor interesse de seu filho. Pelo contrário, nesses casos, a presunção é de que - se estão no pleno exercício da autoridade parental, salvo motivo justificado - as decisões parentais tomadas em relação à vida de seus filhos deverá prevalecer, sobrepondo-se ao intervencionismo estatal disposto para hipóteses, em tese, diversas. Na análise do caso concreto, caberá aos avós provar que ambos os pais assumiram posição que contraria o melhor interesse de seu filho, uma vez que o direito de visitação avoenga, como nenhum outro, não é absoluto ${ }^{105}$.

Por fim, conclui-se que a interferência do Estado garantindo a visitação avoenga é pautada no direito fundamental do menor de convívio familiar. Todavia, até mesmo o convívio familiar deve ser interpretado de acordo com o principio do melhor interesse da criança.

Deste modo, a interferência do Estado na decisão familiar sobre interromper um convívio entre avós e netos, deve sofrer modulações a depender do caso em questão. Não obstante o interesse público sobre o assunto, não se pode desconsiderar, por completo, a opinião dos pais e a raiz de todo o conflito. A noção que deve prevalecer é sempre a que corresponde com o melhor interesse da criança.

\subsubsection{Guarda compartilhada: intervenção estatal tornando a opção como regra.}

A positivação e, consequente regulamentação da visitação avoenga não é o único exemplo que pode ser dado ao se falar em intervenção estatal na tomada de decisões por parte da autoridade parental. Dentre um universo de exemplificações a serem dadas, cabe trazer ao nosso estudo a questão da imposição da guarda compartilhada como regra quando não se chega a um consenso entre os genitores.

Antes que se adentre ao mérito da questão, importante esclarecer que guarda e autoridade parental em nada se confundem ${ }^{106}$. Sendo assim, dispõe o art. 1.579 do Código Civil "o divórcio não modificará os direitos e deveres dos

\footnotetext{
${ }^{105}$ VILELA MULTEDO, Renata. Liberdade e família: limites para intervenção do Estado nas relações conjugais e parentais. Rio de Janeiro: Processo, 2017, p. 171.

106 Art. 1632 do Código Civil: "a separação judicial, o divórcio e a dissolução da união estável não alteram as relações entre pais e filhos senão quanto ao direito, que aos primeiros cabe, de terem em sua companhia os segundos".
} 
pais em relação aos filhos" e o art. 1.634 do mesmo diploma legal esclarece que “compete a ambos os pais, qualquer que seja a situação conjugal, o pleno exercício do poder familiar". Sendo assim, não restam dúvidas que o divórcio, a separação ou a dissolução da união estável em nada vão alterar o exercício do poder familiar que, por sua vez, permanece intacto ${ }^{107}$.

Sob esse aspecto, leciona ROLF MADALENO:

O divórcio ou a separação fática dos pais não repercute nas regras de atribuição do exercício do poder familiar, que é desempenhado em conjunto com o outro genitor, cuja atividade compreende os aspectos pessoais e patrimoniais relacionados com a prole (...). ${ }^{108}$

Posto isso, passa-se ao estudo da inovação quanto ao instituto da guarda compartilhada ser entendida nos dias de hoje como regra. Como é de notório conhecimento, o divórcio é muito comum na sociedade brasileira. Esse procedimento, em muitas de suas vezes, é acompanhado de uma grande carga emocional e acaba por afetar de forma substancial os filhos decorrentes daquele casamento que não mais vigora.

Objetivando a proteção dos filhos quando do divórcio de seus pais, o ordenamento jurídico brasileiro foi contemplado com a Lei 11.698 de 13 de junho de $2008^{109}$ que introduziu a guarda compartilhada. Não fosse suficiente a introdução do instituto, poucos anos depois, mais precisamente em 2014, a Lei $13.058^{110}$ de 22 de dezembro tornou a guarda compartilhada como regra no ordenamento, deixando assim então a guarda unilateral como exceção, cabendo nos casos em que um dos genitores declare expressamente a ausência de interesse ou de condição de exercer a guarda de seu filho ou ainda, nos casos em que haja suspensão ou destituição do poder familiar por um dos pais.

\footnotetext{
107 TEPEDINO, Gustavo. A disciplina da guarda e a autoridade parental na ordem civil-constitucional. Revista Trimestral de Direito Civil, v. 17, n. 5, p. 41-42, 2004.

${ }^{108}$ MADALENO, Rolf. Curso de Direito de Família. $6^{\mathrm{a}}$ ed. ver., atual e ampl. - Rio de Janeiro: Forense, 2015 , p. 464.

${ }^{109}$ Disponível em <http://www.planalto.gov.br/ccivil_03/_ato2007-2010/2008/lei/111698.htm>. Acessado em 26 de abril de 2018.

${ }^{110}$ Disponível em <http://www.planalto.gov.br/ccivil_03/_ato2011-2014/2014/lei/113058.htm>. Acessado em 26 de abril de 2018.
} 
Logo, no nosso ordenamento vigora a regra de que "quando não houver acordo entre a mãe e o pai quanto à guarda do filho, encontrando-se ambos os genitores aptos a exercer o poder familiar, será aplicada a guarda compartilhada, salvo se um dos genitores declarar ao magistrado que não deseja a guarda do menor"111.

Essa inovação normativa foi substancial para o direito de família. Antes da inclusão da matéria no ordenamento jurídico, cabia ao julgador decidir, em caso de litigio, com quem ficaria a guarda do menor e, geralmente, isso se dava "com ampla tendência para custódia materna, especialmente quando os filhos ainda tinham pouca idade" ${ }^{, 12}$.

Desta forma, se percebe facilmente o objetivo do instituto da guarda compartilhada, qual seja, "o de assegurar o direito à convivência familiar, em sua maior plenitude possível, convocando ambos os pais a assumirem de forma efetiva o conteúdo da autoridade parental" ${ }^{113}$.

Entretanto, embora o intuito da guarda compartilhada seja extremamente digno, não se pode fechar os olhos para todas as situações críticas que dela decorrem. A partir dessa ideia, o legislador previu através do parágrafo $3^{\circ}$ do art. 1.584 do Código Civil ${ }^{114}$, a possibilidade do magistrado durante uma eventual ação de guarda, tanto de ofício como a requerimento do Ministério Público, recorrer ao auxílio de equipes interdisciplinares para que assim, possa decidir a respeito das atribuições a serem incumbidas a cada um dos genitores.

Não é com rara frequência que, fundamentando-se no instituto da guarda compartilhada, genitores ingressam no Poder Judiciário requerendo revisão ou, até mesmo, a extinção de pensão alimentícia. Como bem preceitua o Enunciado

\footnotetext{
${ }^{111}$ Art. 1.584, parágrafo $2^{\circ}$ do Código Civil.

${ }^{112}$ MADALENO, Rolf. Curso de Direito de Família. $6^{\text {a }}$ ed. ver., atual e ampl. - Rio de Janeiro: Forense, 2015, p. 464.

${ }^{113}$ TEIXEIRA, Ana Carolina Brochado. A (des) necessidade da guarda compartilhada. In: TEIXEIRA, Ana Carolina Brochado; RIBEIRO, Gustavo Pereira Leite (Coords.) Manual de direito das famílias e das sucessões. Belo Horizonte: Del Rey, 2008, p. 315 Apud VILELA MULTEDO, Renata. Liberdade e família: limites para intervenção do Estado nas relações conjugais e parentais. Rio de Janeiro: Processo, 2017, p. 139.

${ }^{114}$ Art. 1.584, parágrafo $3^{\circ}$ : Para estabelecer as atribuições do pai e da mãe e os períodos de convivência sob guarda compartilhada, o juiz, de ofício ou a requerimento do Ministério Público, poderá basear-se em orientação técnico-profissional ou de equipe interdisciplinar, que deverá visar à divisão equilibrada do tempo com o pai e com a mãe.
} 
$n^{\circ} 607$ da VII Jornada de Direito Civil ${ }^{115}$, o instituto da guarda compartilhada não enseja no direito de se exonerar da pensão alimentícia, afinal são duas situações que possuem diretrizes completamente distintas ${ }^{116}$.

Outra situação crítica que vem aparecendo com regularidade nos tribunais brasileiros, tem seu nascedouro na leitura literal do artigo 1.584 , parágrafo $3^{\circ}$ mencionado supra. Este dispõe que a decisão do magistrado em processos envolvendo guarda de menores, deverá visar à divisão equilibrada de tempo entre o pai e a mãe. Entretanto, essa disposição deve ser observada com cautela, afinal, não parece saudável à rotina do menor, um jogo de "idas e vindas" entre as casas de seus genitores.

Sob esta égide, o magistrado deve estar atento à idade da criança, a rotina na qual ele está inserida, a distância entre não só as residências, como também entre as residências e as instituições de ensino nas quais a criança está matriculada, dentre diversas outras características inerentes ao caso concreto.

Destaca-se assim, a inaplicabilidade literal da lei em favor do melhor interesse do menor. A guarda compartilhada, portanto, não pressupõe uma divisão de tempo igualitária entre os pais e, sim, a responsabilização conjunta dos genitores em relação às tomadas de decisões importantes da vida dos filhos em comum, de acordo com as peculiaridades da vida de cada um ${ }^{117}$.

As discussões que giram em torno da guarda compartilhada, não cessam por aí:

\footnotetext{
${ }^{115}$ Enunciado $n^{\circ} 607$ da VII jornada de direito civil: "A guarda compartilhada não implica ausência de pagamento de pensão alimentícia". Disponível em < http://www.cjf.jus.br/enunciados/enunciado/843>. Acessado em 26 de abril de 2018.

${ }^{116}$ Ementa de um acórdão proferido no Tribunal de Justiça do Distrito Federal sobre o tema: CIVIL. ALIMENTOS. EXONERAÇÃO. GUARDA COMPARTILHADA. IMPOSSIBILIDADE. I. A exoneração do encargo alimentício depende da comprovação de que houve modificação nas possibilidades financeiras de quem os supre ou nas necessidades de quem os recebe (art. 1.699 do Código Civil). II. A guarda compartilhada, por si só, não afasta a obrigação alimentar, mormente quando o lar de referência não é o do alimentante. III. Negou-se provimento ao recurso. (Tribunal de Justiça do Distrito Federal. Apelação n. 20150111385846. Relator: Desembargador José Divino, Sexta Turma Cível, Brasília, Julgamento: 08/03/2017).

${ }^{117}$ Enunciado $n^{\circ}$ 605: O tempo de convívio com os filhos "de forma equilibrada com a mãe e com o pai" deve ser entendido como divisão proporcional de tempo, da forma que cada genitor possa se ocupar dos cuidados pertinentes ao filho, em razão das peculiaridades da vida privada de cada um.
} 
O debate principal é se a vigente normativa determina que o magistrado envide máximos esforços para aplicar a guarda compartilhada - seja através da mediação, seja da conciliação - ou se vai além e obriga o juiz a impor a guarda compartilhada mesmo diante da absoluta impossibilidade de consenso entre os pais, ou seja, nos casos de tamanha animosidade que nem ao menos se consiga garantir efetivamente que a integridade psíquica dos filhos restará incólume. ${ }^{118}$

A resposta para a problemática apontada segue a mesma direção de diversas outras envolvendo crianças e adolescentes. Assim sendo, o magistrado não está obrigado a determinar a guarda compartilhada, sem, contudo, verificar se a mesma está em condições de ser determinada. Essa análise por parte do magistrado deve ser realizada sob a ótica do principio da dignidade humana, cumulado com o princípio do melhor interesse do menor ${ }^{119}$.

Deste modo, quando os aludidos princípios não forem ser concretizados com a aplicação da guarda compartilhada, esta, por motivos lógicos perde a razão de existir no caso concreto ${ }^{120}$. Curioso observar outro ponto interessante em relação à guarda compartilhada, onde de acordo com a determinação legal, inexistindo acordo entre os genitores, deverá ser empregada tal modalidade de guarda. Ora, essa determinação parece minimamente paradoxal ao passo que,

\footnotetext{
${ }^{118}$ VILELA MULTEDO, Renata. Liberdade e família: limites para intervenção do Estado nas relações conjugais e parentais. Rio de Janeiro: Processo, 2017, p. 145.

${ }^{119} \mathrm{Com}$ o fito de demonstrar a atuação dos tribunais, no sentido de preservar o melhor interesse da criança, apresenta-se a ementa de um acórdão julgado recentemente, no final do ano de 2017 no Rio Grande do Sul: Apelação cível. Família. Guarda. Nulidade da sentença, por ausência de fundamentação. Inocorrência. Deferimento da guarda unilateral ao genitor, com regulamentação de visitas maternas. Resguardo do superior interesse da criança. 1. Não é nula a sentença que se pronuncia, de forma fundamentada, sobre tese arguida pela parte, e a rejeita. 2. A definição da guarda deve ser norteada pelo resguardo do superior interesse da criança, e não meramente pela vontade dos genitores. O conjunto probatório carreado aos autos aponta, cabalmente, que o genitor é que reúne melhores condições de exercer, ao menos por ora, a guarda do filho, sem prejuízo do direito da criança de conviver com a genitora, direito este que foi assegurado, mediante a regulamentação de visitas. Negaram provimento. Unânime. (Tribunal de Justiça do Estado do Rio Grande do Sul. Apelação n. 70073059586. Relator: Desembargador Luiz Felipe Brasil Santos, Oitava Câmara Cível, Rio de Janeiro, Julgamento: 23/08/2017).

${ }^{120}$ Neste sentido, o TJRS se posicionou: Agravo de instrumento. Família. Ação de alteração de guarda, cumulada com revisão de alimentos. Estabelecimento da guarda compartilhada. Lei 13.058/2014. Indeferimento na origem. Manutenção. Inadequado, por ora, o estabelecimento da guarda compartilhada, devendo ser prestigiada a cautela do magistrado singular, que desacolheu o pleito diante da ausência de motivos para modificar a situação fática antes da instrução do processo, o que sinaliza não haver indicativos de que o regime pretendido efetivamente viria a atender aos superiores interesses da criança, que necessariamente devem prevalecer. Agravo de instrumento desprovido. (Tribunal de Justiça do Rio Grande do Sul. Agravo de Instrumento No 70066315938, Relator: Desembargador Ricardo Moreira Lins Pastl, Oitava Câmara Cível, Porto Alegre, Julgamento: 12/11/2015).
} 
como é de elementar conhecimento, conflitos familiares ultrapassam em muito a esfera jurídica.

Deste modo, pode-se considerar muita ingenuidade do legislador, quando este determina que a tomada de decisões em relação ao filho comum, vai se suceder de maneira conjunta entre um ex-casal que possui desavenças extremas entre si. Entretanto, é válido repetir, sob risco de cometer repetição enfadonha, que em primeiro plano, deve estar presente a observância do principio do melhor interesse da criança. Por esta razão, não é qualquer tipo de desavença que pode ser responsável pela não determinação da guarda compartilhada.

Por fim, diante de todo o cenário apresentado, questiona-se a real validade existente na delegação ao Estado de determinadas escolhas que, por sua vez, poderiam ser tomadas em âmbito familiar. Como bem destaca GUSTAVO TEPEDINO "a regulação das instituições familiares deve pressupor da prévia análise e reserva de espaços de autonomia, uma vez que a intervenção estatal pode se colocar em crise a percepção do privado como espaço de liberdade" $" 121$.

O direito de família é um ramo do direito privado e, apesar de determinados assuntos pertencerem a interesse coletivo, o mencionado direito não pode ser visto como uma ramificação do direito público. Sendo assim, não se pode perder de vista, os limites existentes na atuação do Estado em tomadas de decisões que deveriam ser orientadas, sobretudo na autonomia privada.

As críticas existentes em relação às intervenções estatais no âmbito da família são inúmeras. Porém, a inovação positiva jurídica trazida pela Lei 13.058 de 22 de dezembro de 2014 ao cenário das modalidades de guarda, não pode ser anulada diante dos problemas dela decorrentes. Até porque, seus objetivos são louváveis e, visa em sua maneira geral, concretizar um dos princípios fundamentais das crianças e dos adolescentes, o do convívio familiar, assim como a visitação avoenga trazida anteriormente a este estudo.

Não se pode negar que com o advento da guarda compartilhada, o ambiente familiar tornou-se mais democrático, composto por mais diálogo.

${ }^{121}$ TEPEDINO, Gustavo. Editorial. Revista Trimestral de Direito Civil. Rio de Janeiro, v. 47, 2011. 
Diante da experiência que a família brasileira está vivendo, notam-se comportamentos mais responsáveis e maduros dos pais separados, visando o bem do filho em comum.

Neste diapasão, não se pode reputar a guarda compartilhada como um todo, ao mesmo tempo, que não é prudente considerá-la absoluta, sem, contudo, analisar o caso concreto de maneira individualizada. Nesta égide, é de se considerar que ninguém mais apropriado do que os próprios membros da família, para decidirem o que é melhor para seu núcleo familiar. Para que essa decisão seja tomada com todo cuidado que se requer, as desavenças e os ânimos aflorados devem ser ultrapassados, o que às vezes, mostra-se impossível de ocorrer, motivo pelo qual a intervenção estatal se faz necessária afim de que não recaia sobre o menor, qualquer maleficio evitável.

\subsection{Autoridade parental versus a autonomia da criança e do adolescente: o dever de cuidado em choque com a função emancipatória.}

Ultrapassada a análise da intervenção estatal nas decisões a serem tomadas pela família, cumpre-se necessário partir para um olhar voltado para dentro do seio familiar, ou seja, passa-se a analisar a autonomia da criança e do adolescente perante a autoridade parental.

Não há como dissertar a respeito da autonomia da criança e do adolescente dentro da sua respectiva família sem mencionar, de forma breve, tema já estudado anteriormente, qual seja, a constitucionalização da família, o processo de reconhecimento da dignidade do infante e seu novo posicionamento.

Com o advento da Constituição Federal de 1988, pode-se dizer que os princípios fundamentais inerentes às crianças e aos adolescentes ultrapassaram a esfera pública, atingindo a esfera privada. No ano seguinte a promulgação da CRFB vigente, a Convenção sobre os Direitos da Criança, formalizada pela Organização das Nações Unidas entrou em vigor, inspirada na Declaração Universal dos Direitos das Crianças datada de 1959. 
Esse processo de reconhecimento de direitos das crianças fez com que o mundo as visse como indivíduos dotados de direitos e em fase de desenvolvimento:

(...) um ser humano, ser em desenvolvimento, especialmente vulnerável, mas dotado de uma capacidade progressiva, igual em dignidade ao adulto, sujeito ativo na construção de seu futuro numa relação intersubjetiva com os pais, titular de direitos fundamentais. ${ }^{122}$

O Brasil então, através do Decreto 99.710 de 21 de novembro de 1990 promulgou a mencionada Convenção que em seu artigo $12^{123}$ dispõe "os Estados Partes assegurarão à criança que estiver capacitada a formular seus próprios juízos o direito de expressar suas opiniões livremente sobre todos os assuntos relacionados com a criança, levando-se devidamente em consideração essas opiniões, em função da idade e maturidade da criança".

Um pouco antes do Decreto mencionado supra, ingressou no ordenamento jurídico o Estatuto da Criança e do Adolescente (13 de julho de 1990) que incumbiu à sociedade, ao Estado e as famílias o dever de priorizar e garantir de forma absoluta uma série de direitos aos menores de idade de forma apta a protegê-los de toda forma de exploração, discriminação, negligência e violência.

De acordo com essas mudanças legislativas, o infante foi realocado para o centro do núcleo familiar, sendo este o responsável direto pelo seu desenvolvimento psicofísico de maneira sadia. Na família democrática - modelo de família tido como ideal nos dias atuais -, a promoção da personalidade de cada um dos seus membros é fundamental, bem como o diálogo e o afeto partilhado.

Sob esta égide, não há espaço para uma família patriarcal pautada na ideia obsoleta do pátrio poder. O poder parental nos dias de hoje tem o dever de "atender os interesses da criança e do adolescente, criando, assistindo e educando-os; enfim, promovendo a personalidade e edificando a autonomia (e

\footnotetext{
${ }^{122}$ MARTINS, Rosa. Responsabilidades parentais no século XXI: a tensão entre o direito de participação da criança e a função educativa dos pais. In: PEREIRA, Tânia da Silva; OLIVEIRA, Guilherme de (Coords). Cuidado e Vulnerabilidade. São Paulo: Atlas, 2009, p. 86-87.

123 Decreto 99.710 de 21 de novembro de 1990. Disponível em <http://www.planalto.gov.br/ccivil_03/decreto/1990-1994/d99710.htm>.Acessado em 30.04.2018.
} 
autorresponsabilidade) da prole com o fim de ajudá-los a superar suas vulnerabilidades" ${ }^{124}$.

Deste modo, é inconteste a necessidade de reconhecimento e promoção da personalidade da criança aliada com sua progressiva autonomia dentro do seio familiar. O processo digno de emancipação do menor deve ser um dos maiores focos da autoridade parental, como destaca o doutrinador GUSTAVO TEPEDINO:

Na concepção contemporânea, a autoridade parental não pode ser reduzida, portanto, nem a uma pretensão juridicamente exigível, em favor de seus titulares, nem a um instrumento jurídico de sujeição (dos filhos à vontade dos pais). Há de se buscar o conceito da autoridade parental na bilateralidade do diálogo e do processo educacional, tendo como protagonistas os pais e os filhos, informados pela função emancipatória da educação ${ }^{125}$.

Assim sendo, com a evolução dos direitos das crianças e dos adolescentes e com o processo de constitucionalização da família brasileira, a função educativa ganhou força e ao mesmo tempo sofreu modificações substanciais. Isso porque, como é de notório conhecimento, a educação mostra-se como elemento fundamental para o progresso da autonomia, uma vez que quanto mais se aprende, mais autonomia se obtém ${ }^{126}$.

É sob essa perspectiva que os deveres inerentes ao poder familiar são enquadrados, ou seja, com foco voltado para promoção do desenvolvimento do infante baseado na educação e seu consequente caráter emancipatório.

Com isso, GUSTAVO TEPEDINO entende que "a interferência na esfera jurídica dos filhos só encontra justificativa funcional na formação e no desenvolvimento da personalidade dos próprios filhos, não caracterizando posição de vantagem juridicamente tutelada em favor dos pais" 127 .

\footnotetext{
${ }^{124}$ MACHADO, Diego Carvalho. Capacidade de agir e situações subjetivas existenciais: o exercício de situações existenciais pela pessoa adolescente a partir de um regime jurídico não codificado. Revista trimestral de direito civil, v. 46, p. 3-51, abril/julho de 2011, p. 41.

${ }^{125}$ TEPEDINO, Gustavo. A disciplina da guarda e a autoridade parental na ordem civil-constitucional. Revista Trimestral de Direito Civil, v. 17, p. 33-49, 2004 p. 38.

${ }^{126}$ STANCIOLI, Brunello Souza. Sobre a capacidade de fato da criança e do adolescente: sua gênese e desenvolvimento na família. Porto Alegre: Revista Brasileira de Direito de Família, p. 37-42, no 2, julago-set, 1999. p. 37.

${ }_{127}$ TEPEDINO, Gustavo. A disciplina da guarda e a autoridade parental na ordem civil-constitucional. Revista Trimestral de Direito Civil, v. 17, p. 33-49, 2004 p. 42.
} 
A partir dessa noção trazida pelo ilustre doutrinador, surge um ponto crítico entre o dever de cuidado e o dever de emancipar dos pais. Essa questão atinge seu ápice quando se está diante de uma situação, na qual se requer uma tomada de decisão em relação à vida do menor, e há divergência entre a escolha dos pais e a vontade do infante. Isso porque, a decisão quando trata da vida do pequeno deve ser norteada pelo dever de cuidado, este exercido pelos seus pais, ao mesmo tempo em que se deve observar a vontade individual do menor, sob quem irá recair as consequências da escolha.

Para se chegar a uma resposta perante esse choque entre vontades, devese levar em consideração a natureza da problemática tratada, caso seja de cunho subjetivo existencial - questões relacionadas ao ser e não ao ter -, a vontade privada deve prevalecer mesmo se tratando de um individuo menor de idade $^{128}$. Assim o é, porque a depender do desenvolvimento, a criança ou o adolescente é dotado de certo discernimento capaz de decidir sobre determinados assuntos.

Existem certas decisões, que somente o próprio individuo deve tomar sobre si, uma vez que dizem respeito à formação de sua própria personalidade ${ }^{129}$. Logo, conclui-se que os pais devem permitir o desenvolvimento da identidade e personalidade de criança de maneira livre, sem se olvidarem, contudo, do dever de cuidado quem têm para com ela.

Esses momentos de conflito entre um dever e outro, tornam evidente a importância da busca pelo efetivo melhor interesse do menor, que pode ser muitas vezes alcançado levando-se em consideração as suas vontades, a depender do seu discernimento para tal. O discernimento vai ser adquirido com o passar do tempo e, seu alcance está intimamente relacionado com a função educacional da família. Neste sentido, ROSA MARTINS leciona:

(...) a função de proteção, dominante nos primeiros tempos de vida da criança vai perdendo peso à medida que o filho vai crescendo e apresentando um desenvolvimento cada vez maior das suas faculdades. Já a finalidade de promoção da autonomia, pelo

128 GONÇALVES, Camila Figueiredo Oliveria; FILHO, Eginaldo de Oliveira Silva. A autonomia da criança e do adolescente e autoridade parental: entre o cuidado e o dever de emancipação. Fortaleza. 18 p. Artigo Jurídico (Pós Graduação em Direito Constitucional) - Universidade de Fortaleza., p. 10.

${ }_{129}$ TEPEDINO, Gustavo. A disciplina da guarda e a autoridade parental na ordem civil-constitucional. Revista Trimestral de Direito Civil, v. 17, p. 33-49, 2004 p. 34. 
contrário, vai-se intensificando com o crescimento do filho. Na verdade, o apoio dos pais com vista ao desenvolvimento integral e harmonioso da personalidade do filho vaise tornando cada vez mais necessário à medida que este vai crescendo ${ }^{130}$.

Um ponto importante a ser levantado nessa discussão, é o ponto de vista do adolescente, que por sua vez, não é tratado como se fosse criança, entretanto, também não chega a ser tratado como adulto. É nesta fase "que a pessoa desvincula-se das estruturas de proteção e da segurança provida pelos pais na infância para se emancipar num processo de busca pela autonomia em diferentes contextos e através de diferentes áreas do processo decisório" ${ }^{131}$.

Sendo assim, em relação aos adolescentes o dever emancipatório se mostra mais latente do que o de proteção, entretanto, este subsiste. $\mathrm{O}$ respeito pelas escolhas individuais deve ocupar maior espaço em relação às crianças, tendo-se em vista o maior discernimento alcançado.

Sob esta ideia, chega-se a conclusão que o poder familiar deve ser balanceado entre o respeito à autonomia da criança e do adolescente, a promoção da emancipação do menor, este relacionado com a função educativa, e o dever de cuidado. Logo, percebe-se que a decisão dos pais sob os filhos não deve ser tomada de maneira a atender só o que os pais pensam que seja correto ou ideal, sem considerar as opiniões de quem vai recair a decisão, ao contrário, a observância em relação às vontades das crianças e dos adolescentes é fundamental.

Em relação a estas vontades, deve-se ter em mente a avaliação do discernimento do menor. A partir do momento que seu discernimento for suficiente para tomada daquela decisão, sua vontade deve ser respeitada, sobretudo em situações subjetivas existenciais.

Diante deste cenário, equalizam-se duas variáveis, a autonomia da criança e do adolescente e o dever de proteção dos pais. A autonomia do infante é cada

\footnotetext{
130 MARTINS, Rosa. Responsabildiades parentais no século XXI: a tensão entre o direito de participação da criança e a função educativa dos pais. In: PEREIRA, Tânia da Silva; OLIVEIRA, Guilherme de (Coords). Cuidado e Vulnerabilidade. São Paulo: Atlas, 2009.p. 92.

${ }^{131}$ GONÇALVES, Camila Figueiredo Oliveria; FILHO, Eginaldo de Oliveira Silva. A autonomia da criança e do adolescente e autoridade parental: entre o cuidado e o dever de emancipação. Fortaleza. 18 p. Artigo Jurídico (Pós Graduação em Direito Constitucional) - Universidade de Fortaleza., p. 14.
} 
vez maior à medida que a proteção dos pais vai se tornando menor. E, por sua vez, este dever vai tendo cada vez mais limites com o passar da idade e do desenvolvimento dos pequenos. Essa equação é capaz de solucionar, na grande maioria dos casos, o possível empasse existente entre a autoridade parental e a autonomia dos seus filhos.

A avaliação do discernimento para as tomadas de decisões do infante é tão relevante que, o ordenamento jurídico brasileiro admite a chamada emancipação, ou seja, a aquisição da plena capacidade civil do adolescente antes de se atingir a maioridade por entender que este é capaz para tal. Ou seja, atribui-se autonomia civil quase em seu estado pleno às crianças e adolescentes menores de 18 anos. A emancipação pode decorrer do entendimento voluntário dos pais do infante (via voluntária), da lei (via legal) ou de uma decisão judicial (via judicial). Posto isso, passa-se ao estudo mais aprofundado deste instituto previsto na lei brasileira.

\subsection{O instituto da emancipação: atribuição da capacidade civil aos menores de 18 anos.}

Optou-se por estudar o instituto da emancipação ao final deste Capítulo, levando-se em consideração que o objeto desta análise está intimamente ligado tanto à intervenção estatal nas decisões tomadas pela família, tanto à situação envolvendo as escolhas da autoridade parental e autonomia de seus filhos.

Assim o é, uma vez que a emancipação, entendida como "ato jurídico que antecipa os efeitos da aquisição da maioridade e da consequente capacidade civil plena, para data anterior àquela em que o menor atinge a idade de 18 anos, para fins civis" ${ }^{132}$, pode ser um exemplo de intervenção estatal nas decisões familiares, uma vez que pode ocorrer por determinação judicial ou previsão legal e, ao mesmo tempo, a emancipação pode-se dar por vontade dos pais do menor, por estes entenderem que seu filho já possui o discernimento necessário para práticas dos atos civis.

\footnotetext{
${ }^{132}$ TARTUCE, Flávio. Manual de direito civil: volume único. $7^{\mathrm{a}}$ ed. ver., atual e ampl. Rio de Janeiro: Forense; São Paulo: MÉTODO, 2017, p. 96.
} 
Esse instituto não se confunde com a maioridade civil, o infante continua sendo menor de idade, o que implica na incidência do Estatuto da Criança e do Adolescente sobre ele. A emancipação é somente responsável pela retirada do manto de incapacidade, fazendo com que o menor de 18 anos se torne capaz no mundo jurídico.

A incapacidade civil cessa para os menores quando: há essa concessão dos pais, ou de um deles na falta de outro, mediante instrumento público aos filhos menores com 16 anos completos, o que vai independer da homologação judicial; por sentença judicial, quando o menor tiver 16 anos completos, desde que escutado seu tutor; através do casamento; pelo exercício público efetivo; pela colação de grau em curso de ensino superior ou, ainda, pela existência de estabelecimento civil ou comercial do qual o menor com 16 anos completos tenha a própria economia ${ }^{133}$.

De maneira geral, a emancipação é definitiva, irretratável e irrevogável, contudo, quando essa se dá por concessão dos pais ou por sentença judicial, se sujeita a desconstituição por vício de vontade, caso exista ${ }^{134}$. O parágrafo único do artigo $5^{\circ}$ do Código Civil e seus incisos são taxativos, ou seja, não se tratam apenas de exemplos dos quais cabem à emancipação e sim, de situações únicas nas quais esse instituto será cabível.

\subsubsection{Emancipação voluntária parental.}

A emancipação voluntária parental consiste em um "ato unilateral de ambos os pais, que declaram estar o filho maior de dezesseis anos e menor de dezoito anos de idade apto para exercer todo e qualquer ato da vida civil, regendo plenamente sua pessoa e bens" ${ }^{\prime 135}$.

$\mathrm{Na}$ emancipação voluntária, os pais realizam a tão falada e necessária avaliação do discernimento do menor e, alcançam a conclusão, que o mesmo é

\footnotetext{
133 Art. 5o parágrafo único e incisos do Código Civil Brasileiro. Disponível em <http://www.planalto.gov.br/ccivil_03/leis/2002/110406.htm>. Acessado em 30 de abril de 2018.

${ }^{134}$ TARTUCE, Flávio. Manual de direito civil: volume único. $7^{\mathrm{a}}$ ed. ver., atual e ampl. Rio de Janeiro: Forense; São Paulo: MÉTODO, 2017, p. 96.

${ }^{135}$ NERY JUNIOR, Nelson. Código Civil comentado. 11 ed. rev., ampl. e atual. São Paulo: Editora Revista dos Tribunais, 2014. p. 302.
} 
plenamente capaz para gerir sua vida e seu patrimônio. A norma não trata da participação do menor no ato de concessão da emancipação realizado pelos pais, sendo assim, não se trata de um ato onde a vontade do menor prevalece em totum. Contudo, com o intuito de se evitar possíveis confusões, é cauteloso que o menor participe do ato como anuente, vez que se podem levantar dúvidas a respeito da real intenção dos pais quanto ao processo emancipatório.

O pode familiar após os avanços da sociedade como foi visto, é exercido tanto pelo pai quanto pela mãe. Sendo assim, para que se tenha a emancipação do filho em comum de maneira que não haja necessidade de prévia homologação judicial, essa tomada de decisão quanto à emancipação, deve ser feita de forma conjunta.

Entretanto, nos deparamos com situações onde o pai, por exemplo, não consta na certidão de nascimento do menor, desta maneira, a emancipação pode se dar de maneira exclusiva pela mãe. A emancipação é um ato solene, razão pela qual, deve ser feita através de escritura pública, sob pena de nulidade ${ }^{136}$.

\subsubsection{Emancipação judicial.}

A emancipação judicial por sua vez, decorre de uma sentença judicial, como o próprio nome diz que, vem a ser dada, tanto por um desentendimento entre os pais, ou seja, uma eventual discordância que possa ter surgido, tanto pelo entendimento do tutor que o tutelado já possui capacidade para gerir seus bens e sua vida.

A emancipação judicial, por razões claras, não está submetida à escritura pública. Entretanto, tanto a emancipação voluntária como a emancipação judicial, “devem ser registradas no Registro Civil das pessoas naturais, sob pena de não produzirem efeitos (art. 107, parágrafo $1^{\text {o }}$, da Lei 6.015/1973 - LRP)" ${ }^{137}$.

Por mais que se trate de uma jurisdição voluntária, na emancipação judicial, há a intervenção do estado na decisão de âmbito familiar, uma vez que

\footnotetext{
${ }^{136}$ Ibid. p. 303.

${ }^{137}$ TARTUCE, Flávio. Manual de direito civil: volume único. $7^{\mathrm{a}}$ ed. ver., atual e ampl. Rio de Janeiro: Forense; São Paulo: MÉTODO, 2017, p. 96.
} 
os membros da família não chegam a um acordo sobre o assunto. Logo, transfere-se o direito de emancipar ou não o filho em comum do casal ao Estadojuiz.

\subsubsection{Emancipação legal.}

Por fim, ultrapassadas as análises quanto à emancipação judicial e voluntária, passa-se ao estudo da emancipação legal, onde se trata dos casos que o menor com 16 anos completos pode ser emancipado simplesmente por se enquadrar nas hipóteses previstas em lei.

A primeira dessas hipóteses é a emancipação derivada do casamento do menor. De acordo com o art. 1.517 do Código Civil, a idade núbil é de 16 anos, independentemente do sexo, sendo possível o casamento mediante autorização dos pais ou de seus representantes. Quando os pais ou os responsáveis anuem com o casamento e, concedem a autorização, automaticamente estão anuindo com a emancipação do menor. Sob esta hipótese legal, FLÁVIO TARTUCE dispõe:

O divórcio, a viuvez e a anulação do casamento não implicam no retorno à incapacidade. No entanto, entende parte da doutrina que o casamento nulo faz com que se retorne à situação de incapaz, sendo revogável em casos tais a emancipação, o mesmo sendo dito quanto à inexistência do casamento. Para outra corrente, como no caso de Pablo Stolze e Rodolfo Pamplona, tratando-se de nulidade e de anulabilidade do casamento, a emancipação persiste apenas se o matrimônio for contraído de boa-fé (hipótese de casamento putativo). Em situação contrária, retorna-se à situação de incapacidade. ${ }^{138}$

Logo, nesta hipótese específica, embora a previsão para emancipação decorra da lei, existe uma anuência por parte dos pais ou do responsável, pelo fato do casamento para os menores de 18 anos não ser realizado quando não concedida autorização.

A segunda previsão legal é a por exercício de emprego público efetivo. Entretanto, há uma peculiaridade nesta situação, o emprego deve ser de

\footnotetext{
${ }^{138}$ Ibid. p. 97.
} 
nomeação definitiva, não cabendo aqui às hipóteses de serviços temporários ou de cargos comissionados.

A terceira previsão legal mostra-se a mais difícil de ocorrer na prática, sendo a emancipação concedida nos casos de colação de grau em curso de ensino superior reconhecido. Levando-se em consideração o tempo de estudo no Brasil, torna-se praticamente impossível a conclusão de um ensino superior antes dos 18 anos, uma vez que o comum é que o ensino médio dure até a maioridade.

Por fim, apresenta-se a hipótese de emancipação legal, por estabelecimento civil ou comercial ou pela existência de relação de emprego, obtendo o menor as suas economias próprias, visando sua subsistência. Essa última hipótese legal nos revela a importância do amadurecimento e da experiência do menor para que esse se torne capaz no mundo civil.

Nesta situação, principalmente, leva-se em consideração a experiência de cada um de maneira individualizada, retirando o manto da incapacidade daqueles que recebem a partir de um salário mínimo devido a uma relação de emprego ou estabelecimento civil ou comercial próprio.

Além dessas hipóteses legais, menciona-se a última delas que é a emancipação do menor militar, este deve possuir 17 anos e estar em exercício para que possa ser emancipado.

Diante de todo o exposto, conclui-se que o menor de idade não só é capaz de ter discernimento para tomadas de certas decisões, como esse discernimento torna-se tão latente que pode chegar a ter o condão de transformar o menor de 16 (dezesseis) anos completos em plenamente capaz para o mundo jurídico.

Assim sendo, não há como ignorar o constante progresso do ser humano e sua consequente conquista de maturidade para tomada de decisões relativas à sua vida. Como exposto anteriormente, esse progresso deve ser impulsionado e observado pela família, berço de todo seu desenvolvimento. A negligência quanto a autonomia da criança e do adolescente sob certas decisões podem gerar consequências irreparáveis, principalmente no que tange as questões subjetivas existenciais. 
A partir disso, adentra-se ao tema do terceiro e último capítulo deste estudo, a autonomia da criança e do adolescente na seara dos direitos da personalidade. 


\section{Capítulo III - Decisões subjetivas existenciais e a preservação da autonomia da criança e do adolescente.}

\subsection{Direitos da personalidade da criança e do adolescente: respeito, exercício e desenvolvimento.}

O direito ao desenvolvimento da personalidade decorre de um direito geral de liberdade e satisfaz um dos pilares do consagrado princípio da dignidade da pessoa humana ${ }^{139}$, razão pela qual tudo que propiciar esse mencionado desenvolvimento de maneira saudável, deve ser tutelado.

Assim, entende-se que o direito ao desenvolvimento da personalidade de maneira geral, "respeita a vontade de cada ser, garante a individualidade, uma vez que não admite intervenções na escolha das opções de vida e determina na maneira que the achar melhor seu modo de vida" ${ }^{140}$.

Sob esta égide, entende-se o ser concomitantemente como objeto e titular do direito tratado:

Eis a razão radical do fundamento último do direito geral de personalidade, ou dos direitos de personalidade, em que a pessoa é, simultaneamente, o objeto e o sujeito de direitos. Em segundo plano, a proteção da pessoa exige a proteção do seu desenvolvimento, da sua maturação, bem como da sua autenticidade como centro de decisão ${ }^{141}$.

Desta maneira, compreende-se como "direitos da personalidade todos aqueles dispersos pelo ordenamento jurídico que asseguram o básico, sem os quais a pessoa humana seria inconcebível"142. Os mencionados direitos da personalidade têm como função satisfazer as necessidades físicas e morais de uma pessoa através da tutela de seus diversos interesses.

\footnotetext{
${ }^{139}$ SARLET. Ingo Wolfgang. A eficácia dos direitos fundamentais. 9 ed. rev., atual e ampl. Porto Alegre: Livraria do Advogado, 2007, p. 100.

${ }^{140}$ PAULA, Bruna Souza; CAÚLA, Bleine Queiroz. Autonomia da Vontade da Criança sob a ótica dos direitos fundamentais - o direito ao livre desenvolvimento da personalidade. Disponível em <http://www.publicadireito.com.br/artigos/?cod=29d74915e1b32367>. Acesso em 20 de maio de 2018.

${ }^{141}$ NETO. Luísa. O direito fundamental à disposição sobre o próprio corpo: a relevância da vontade na configuração do seu regime. Coimbra: Coimbra Editora. 2004. p. 190.

142 NUNES. Lydia Neves Bastos Telles. Respeito aos direitos da personalidade das crianças e adolescentes. Disponível em <https://periodicos.fclar.unesp.br/seguranca/article/view/5027〉. Acessado em 15 de maio de 2018.
} 
Destarte, compreende-se como direitos da personalidade um amplo campo de direitos, onde o direito à saúde, liberdade ou até mesmo à vida, são meramente exemplificativos. De acordo com o Código Civil Brasileiro em seu artigo 2, "a personalidade civil da pessoa começa do nascimento com vida; mas a lei põe a salvo, desde a concepção, os direitos do nascituro". Sendo assim, a partir da primeira respiração do indivíduo este passa a ser dotado de personalidade, personalidade esta que lhe irá acompanhar até seu último dia de vida.

Como explicitado outrora, os direitos da personalidade da criança e do adolescente apresentam em sua expressão, uma certa peculiaridade eis que até atingir a maioridade, esses indivíduos são embarcados no regime de incapacidade, o que restringe a liberdade dos mesmos, garantindo um sistema de intervenções na vida dos pequenos.

As aludidas intervenções foram tema de estudo em momentos anteriores, sendo, via de regra, realizadas sobretudo pela família. A partir dessa compreensão, e, considerando que é dever da família garantir o desenvolvimento sadio da personalidade do menor de idade, as situações cotidianas acabam por gerar conflitos onde deve-se ponderar a autonomia dos pequenos com o dever de cuidado da família tendo-se em vista a tenra idade dos seus filhos.

Deste modo, não há absolutamente que se falar em ausência do exercício dos direitos da personalidade por parte das crianças e dos adolescentes ao passo que não há que se dizer que esse direito é exclusivo dos mesmos em todas as situações cotidianas, eis que há uma evidente intervenção por parte de terceiros.

Contudo, não se pode olvidar que embora o aludido direito não seja amplamente exercido em todos os momentos de vida dos menores de idade, principalmente no que tange a questão da liberdade de decisão, o mesmo é totalmente tutelado. Neste sentido, defende LYDIA NUNES "a tutela dos direitos da personalidade busca proteger todas as manifestações das pessoas e o respeito ao seu desenvolvimento e a sua capacidade de discernimento" ${ }^{143}$.

${ }^{143}$ NUNES. Lydia Neves Bastos Telles. Respeito aos direitos da personalidade das crianças e adolescentes. Disponível em <https://periodicos.fclar.unesp.br/seguranca/article/view/5027>. Acessado em 15 de maio de 2018. 
Assim como em outros momentos, o discernimento aparece como importante ator na questão dos direitos da personalidade, justificando até mesmo a não exclusividade dos mencionados direitos por parte das crianças e adolescentes. Sobre essa questão JOÃO BAPTISTA VILLELA defende:

O reconhecimento de uma tal zona de capacidade subetária é da maior importância na promoção da autonomia do sujeito. Assim, o exercício de certos direitos da personalidade (...) não devem estar restringidos aos que tenham capacidade no sentido etário, senão reconhecidos e assegurados sempre ali e quando estiver diante de um poder de discernimento quanto à significação básica dos valores em causa ${ }^{144}$.

Diante do exposto, surge a necessidade de uma solução para o impasse travado entre a necessidade de observação do discernimento do infante, o regime de incapacidades e o pleno gozo e exercício dos direitos da personalidade que são conferidos às crianças e aos adolescentes. Como bem destaca, EDGARD NETO “a procura de solução não pode se limitar às posições antagônicas, paternalista (protecionista) ou autonomista (libertacionista)" ${ }^{\prime 145}$.

Sendo assim, passa-se a uma proposta de enxergar o mencionado conflito a partir de um olhar mais objetivo e voltado, principalmente, para os direitos mais subjetivos dos menores de idade, pois são neles que recaem as maiores polêmicas quanto a intervenção de terceiros devido ao seu caráter personalíssimo.

\subsection{Pontos de partida: questões objetivas dentro das decisões subjetivas existenciais.}

No Capítulo anterior, muito se mencionou a respeito das decisões subjetivas existenciais e da importância dessas decisões serem tomadas pelas próprias pessoas nas quais as consequências irão se debruçar. Isso porque, como esclarecido anteriormente, essas questões são de caráter personalíssimo e, seus resultados acabam por formar o seu próprio "ser".

\footnotetext{
${ }^{144}$ VILLELA, João Baptista. O caráter consensual da emancipação nas siete Partidas: um convite à reflexão. separata de: Faculdade de Direito da Universidade de Lisboa. Estudos em Honra de Ruy de Albuquerque. [S.1.]: Coimbra editora, 2006, p. 688.

${ }^{145}$ NETO, Edgard Audomar Marx. Exercício dos direitos da personalidade por criança e adolescentes: entre o exercício exclusivo e regime de incapacidade. Disponível em <https://revistajuridica.presidencia.gov.br/index.php/saj/article/viewFile/152/145>. Acessado em 16 de maio de 2018.
} 
Não obstante a incapacidade absoluta ser incompatível com a ideia de "personalismo", a dignidade humana para ser efetiva depende da liberdade para tomada de decisões desse gênero. Neste sentido, forma-se um impasse onde a autonomia apresenta-se como uma forma de resposta plausível.

Entretanto, a sociedade não parece ser "madura" o suficiente para depositar confiança nessas decisões tomadas especialmente em caráter subjetivo, "desconfiando", portanto, sempre que possível. Há na sociedade uma resistência muito forte em "deixar" as crianças às suas próprias decisões ou às escolhas de seus pais. Diante dessa objeção social, acaba por existir uma dificuldade muito grande em se reconhecer e ampliar a autonomia da criança e do adolescente.

Com o intuito de diminuir essa latente relutância social, cabe trazer à essas questões subjetivas uma avaliação objetiva, como forma de análise alternativa a questão aqui enfrentada.

Essa avaliação será capaz de demonstrar os possíveis "graus" de consequências das decisões existenciais quando tomadas pelas próprias crianças ou adolescentes e, por conseguinte, a autonomia dos mesmos poderá ser mais facilmente reconhecida e aceita pela sociedade, a depender da situação.

A partir dessa ideia, THAÍS SÊCO, propõe uma apreciação dessas decisões baseada no caráter das mesmas, ou seja, se são: reversíveis ou irreversíveis ou ainda se são adiáveis ou inadiáveis ${ }^{146}$. Esses pontos objetivos servem principalmente, como um contraponto às preocupações que se restringem única e exclusivamente na capacidade da criança e do adolescente em tomar certa decisão em razão de seu estágio de desenvolvimento. Nas palavras de THAÍS SÊCO:

Pode-se então dizer que a proposta de categorizar os atos quanto à reversibilidade e adiabilidade não resolve abstratamente os problemas inerentes ao exercício dos interesses existenciais das crianças e adolescentes, mas apenas transfere a discussão para um patamar que parece mais adequado à função estatal de proteção e promoção da infância e da adolescência. ${ }^{147}$

\footnotetext{
${ }^{146}$ SECO, Thaís. A autonomia da criança e do adolescente e suas fronteiras: capacidade, família e direitos da personalidade. 2013. Rio de Janeiro. 175 p. Dissertação (Mestrado em Direito) Universidade do Estado do Rio de Janeiro., p. 102.

${ }^{147}$ Ibid. p. 136.
} 


\subsubsection{Reversibilidade ou Irreversibilidade das decisões.}

A possibilidade de (ir)reversibilidade de uma decisão está diretamente relacionada às consequências dessa ser possível ou não de atenuação ou até mesmo de anulação em algum momento posterior. Por óbvio, as decisões irreversíveis possuem "custos" maiores, ou seja, são mais difíceis de suas consequências serem atenuadas ou anuladas. Por esta razão, as decisões irreversíveis devem ser o mais personalíssimas possíveis, uma vez que uma tomada de decisão heterônoma nesse sentido, pode causar danos irreparáveis em outrem $^{148}$.

Neste sentido, sempre que possível, nas decisões de caráter irreversível deve-se prestigiar a autonomia da criança e do adolescente ou, então, estabelecer uma idade adequada para que aquela decisão em especifico seja tomada pela própria pessoa, caso esteja se tratando de uma decisão adiável ${ }^{149}$.

Quando se admite uma decisão heterônoma sobre um elemento subjetivo de caráter irreversível, está se admitindo a possibilidade de um dano imensurável. Isso porque, por mais bem intencionado que possa estar o tomador de decisão, este pode divergir das ideias e das concepções da pessoa sobre quais essas consequências vão recair. E, justamente, pela noção de irreversibilidade existente nelas, o ser vai ser obrigado a conviver com resultados dos quais não foi ele quem provocou.

Logo, não restam dúvidas quanto a valorização do caráter personalíssimo de tais decisões, razão pela qual deve-se priorizar a autonomia da criança e do adolescente principalmente nesses casos.

\subsubsection{Adiabilidade ou inadiabilidade das decisões.}

Existem decisões ao longo da vida que podem ser adiáveis, tomadas em momentos posteriores, sem que se fale em prejuízos significativos, ao passo que

\footnotetext{
${ }^{148}$ Ibid. p. 121.

${ }^{149}$ Ibid. p. 121.
} 
existem situações de caráter inadiável, ou seja, não há como tomar a decisão se não, no tempo presente.

O que vai definir a adiabilidade ou a inadiabilidade de uma decisão é o subjetivismo de um indivíduo, sua parte mais íntima. Dessa forma, uma decisão que pode ser vista como adiável para muitos, para determinada pessoa não é e, é de acordo com essa identidade personalíssima que a tomada de decisão deve ser baseada.

Sobre este ponto, deve-se ter em mente que a infância bem como a adolescência, são etapas da vida que passam de maneira fugaz, ou seja, o indivíduo não será criança eternamente e nem por um lapso temporal duradouro. Logo, por ser uma situação da qual não é consideravelmente extensa, em determinados casos, mostra-se possível adiar certas decisões para a maioridade ou para qualquer outro tempo que acabe sendo considerada conveniente, prevenindo possíveis consequências drásticas a respeito, ao passo que em determinados momentos isso não será igualmente possível.

A propositura de uma idade para tomada de uma decisão, deve ser impulsionada por estudos interdisciplinares, eis que a Psicologia se mostra mais capacitada a analisar a aquisição progressiva de competência das crianças e dos adolescentes em relação a tomada de certas decisões ${ }^{150}$.

A proposta apresentada não é aumentar, diminuir ou até mesmo eliminar o conceito de maioridade, e sim de se relativizá-la avaliando o discernimento da criança e do adolescente no caso específico, levando-se em consideração o caráter adiável ou não de uma possível decisão, para que o infante possa adquirir cada vez mais autonomia alcançando, por consequência, o apogeu da dignidade.

Sob esta ótica, a Psicologia pode desvendar, por exemplo, a idade que uma criança passa a adquirir consciência sobre determinado assunto e, por esta razão, pode decidir a respeito dele. O caráter adiável ou inadiável de uma decisão também pode ser bastante particular, motivo pelo qual deve ser analisado com muita cautela, sendo a contribuição de outras ciências imprescindível. A ausência

${ }^{150}$ Ibid. p. 123. 
dessa avaliação, tende a tornar as decisões heterônomas como regra e a causar danos significativos, já que, repita-se à exaustão, está se tratando de questões existenciais e de cunho extremamente subjetivo.

\subsubsection{Combinações cabíveis no caso concreto.}

Diante do estudo de possíveis características das decisões a serem tomadas, especialmente no período da infância e da adolescência, THAÍS SÊCO propõe a combinação entre elas ${ }^{151}$ afim de que se avance no sentido de tornar mais objetivo o estudo das decisões subjetivas existenciais por parte das crianças e dos adolescentes.

Assim sendo, sabe-se que as decisões reversíveis não possuem um custo muito significativo na vida de um indivíduo, ainda mais quando cumuladas ao caráter adiável. Eis que sua reversibilidade proporciona um índice danoso infinitamente menor em relação as decisões de cunho irreversíveis. Ou seja, não fosse suficiente os danos não serem drásticos, a decisão é capaz de ser adiada para momento posterior sem que haja um substancial prejuízo à pessoa.

Sendo assim, são as decisões mais simples de serem tratadas de acordo com a subjetividade da família. Logo, as escolhas devem ser realizadas dentro do seio familiar, sendo este democrático o suficiente para que os filhos possam ser ouvidos e suas opiniões serem consideradas.

Ao passo que se tratando de decisões inadiáveis e reversíveis, tem-se basicamente a ideia de que essas precisam ser tomadas mesmo que contra a vontade dos filhos ou de seus pais, porque além de evitarem danos futuros, elas mesmo não ocasionam dano algum $^{152}$.

A respeito das decisões irreversíveis e adiáveis, deve-se ter um olhar mais atento e cauteloso devido aos danos que podem ser ocasionados e impossibilitados de qualquer reparação. Sendo assim, essas decisões não podem ser tomadas de maneira heterônoma. Por possuírem caráter adiável, tais decisões

${ }^{151}$ Ibid. p. 127.
${ }^{152}$ Ibid. p. 127. 
não devem, via de regra, ser tomadas pelos filhos naquele momento onde pende dúvidas a respeito de seu discernimento para tal, em razão da irreversibilidade de suas consequências.

Ao mesmo tempo em que somente as crianças ou os adolescentes em questão poderiam decidir a respeito de si mesmos devido ao caráter personalíssimo que essas decisões têm como característica.

Sendo assim, a solução mais plausível é esperar a maioridade para tomada de decisão ou então, esperar se atingir um discernimento notório que o torne capaz de tomá-la. Exemplo apto a ilustrar esse tipo de decisão é a grande maioria das cirurgias estéticas, onde atribuir a decisão de realizá-la ou não a outra pessoa, pode gerar danos substanciais e, ao mesmo tempo, por possuir caráter meramente estético e não imprescindível a saúde, pode ser uma decisão postergável, podendo ser feita quando houver discernimento suficiente para tal, o que não necessariamente é alcançado somente aos 18 (dezoito) anos.

Por fim, chega-se ao ápice do problema, onde se concentra o maior dilema. Quando as decisões são irreversíveis e inadiáveis, significa que suas consequências não podem ser atenuadas e, muito menos anuladas, entretanto não podem ser tomadas em momento posterior devido aos danos que serão causados se não forem tomadas no momento presente, por essa razão são chamadas de hard cases.

Ora, estamos diante de um impasse significativo: um ato personalíssimo cuja as consequências mostram-se profundas e irreparáveis que deve ser tomado no momento vigente em razão de seus profundos danos caso seja adiado. Para um adulto, essa situação já se demonstraria complexa, aos olhos de uma criança e de um adolescente o grau de complexidade se torna ainda mais profundo.

Diante de todo o exposto, adentra-se a um pequeno "estudo de caso" em relação à direitos da personalidade da criança e do adolescente, sob a ótica e influência dessa análise objetiva anteriormente trazida, bem como de suas consequentes derivações em relação as questões subjetivas dos menores. 
Através desse viés, se buscará alcançar uma visão menos embaçada quanto a autonomia da criança e do adolescente dentro de suas questões personalíssimas, afastando, sempre que possível, as tomadas de decisões heterônomas, aproximando-se por sua vez, de um individualismo que por sua vez, deve ser cauteloso e seguro.

\subsection{Desdobramento dos direitos da personalidade: direito ao nome.}

O nome civil é entendido como um dos direitos da personalidade eis que é inerente à pessoa, integra a sua personalidade, representa um sinal de si mesmo, além de ser a forma como se reconhece aquele indivíduo dentro e fora do seio familiar. Diante de tamanha importância, pode-se compreender a razão do nome ser inalienável e protegido juridicamente ${ }^{153}$.

Entende-se o nome como uma forma de individualização que transpassa a vida. De acordo com o doutrinador SILVIO DE SALVO VENOSA, o nome chega a ser a manifestação mais contundente da personalidade ${ }^{154}$. Com efeito, o nome mostra-se imprescindível para o cumprimento das obrigações bem como o exercício dos direitos ${ }^{155}$.

Compreendendo o nome como um direito do ser humano e, entendendo sua importância na vida do indivíduo, facilmente alcança-se o dano causado quando os pais atribuem aos seus filhos nomes vexatórios. O dano é ainda maximizado quando se reconhece que a regra predominante no direito brasileiro, é da imutabilidade do nome civil. Não obstante a previsão legal constante no parágrafo único do artigo 55 da Lei 6.015 de 31 de dezembro de 1973 (Lei de Registros Públicos) ${ }^{156}$, onde expressamente se determina o não registro de nomes suscetíveis de expor seus portadores ao ridículo, essa atribuição continua sendo muito comum.

\footnotetext{
${ }^{153}$ DINIZ, Maria Helena. Curso de Direito Civil Brasileiro, v. 1: Teoria Geral de Direito Civil, 22 ed. São Paulo: Saraiva, 2005 p. 196.

${ }^{154}$ VENOSA, Silvio de Salvo. Direito Civil: parte geral. Volume 1, 5 ed., São Paulo: Atlas, 2005, p. 210. ${ }^{155}$ Ibid.p. 212.

156 Lei 6.015 de 31 de dezembro de 1973. Disponível em <http://www.planalto.gov.br/ccivil_03/leis/L6015compilada.htm>. Acessado em 27 de maio de 2018.
} 
Apenas à titulo de exemplificação, foram registrados em cartórios brasileiros nomes como Amado Amoroso, América do Sul Brasil de Santana, Alce Barbuda, Amável Pinto, Agrícola Beterraba Areia ${ }^{157}$, dentre outros capazes de expor seus portadores ao extremo ridículo.

Assim sendo, a atribuição de um nome vexatório à uma criança faz com que ela tenha que lidar, por pelo menos, boa parte de sua vida, com situações vergonhosas das quais não se submeteria caso não tivesse esse prenome. Sob esta ótica, depara-se com uma situação crítica onde as crianças são submetidas, por escolha de seus pais, a situações vexatórias e, ao mesmo tempo, não tem capacidade para defender seus interesses.

Como bem destaca THAÍS SÊCO, o nome vexatório:

tem a ver com um desrespeito dos pais pelos próprios filhos, uma desconsideração completa de seus próprios interesses existenciais e uma negativa de sua própria dignidade pela pressuposição de que os filhos seus podem ser reduzidos, por sua vontade, a uma "piada ambulante ${ }^{158}$.

Deste modo, questiona-se a falta de capacidade dos pequenos em pleitearem judicialmente uma mudança de nome, para que assim, não sejam submetidos por toda a fase da infância e da adolescência a passarem por situações das quais os coloquem constrangidos.

Da mesma maneira, questiona-se a representação dos pais nesse caso específico, uma vez que foram eles quem determinaram o nome àquela criança. Ou seja, há um evidente conflito no caso em questão que necessita de uma solução. Isso porque, de um lado verifica-se a ausência de capacidade processual do menor e, do outro, tem-se a representação do infante realizada por seus pais, responsáveis pela existência de seu nome.

Utilizando-se da proposta de trazer os elementos objetivos a estas questões existenciais, pode-se perceber que a mudança ao nome se apresenta como uma decisão irreversível. Contudo, não parece prudente se esquecer que igualmente

157 Disponível em <https://forum.outerspace.com.br/index.php?threads/top-30-nomes-bizarros-járegistrados-em-cartórios-no-brasil.454543/>

${ }^{158}$ SECO, Thaís. A autonomia da criança e do adolescente e suas fronteiras: capacidade, família e direitos da personalidade. 2013. Rio de Janeiro. 175 p. Dissertação (Mestrado em Direito) Universidade do Estado do Rio de Janeiro., p. 124. 
irreversível serão as situações nas quais as crianças e os adolescentes com os nomes vexatórios irão passar. Por tal razão, essa decisão aparenta ter um caráter mais inadiável do que adiável.

Diante de tal análise, podemos concluir que a questão dos nomes vexatórios pode ser incluída nos já mencionados hard cases, vez que sua eventual mudança representa uma decisão irrevogável e tende a ser inadiável eis que esperar chegar até a maioridade causaria danos incalculáveis ao individuo.

Uma situação também curiosa pode ser encontrada ao se analisar o parágrafo 5 do artigo 47 pertencente ao ECA, onde nos casos envolvendo a adoção atribui-se aos menores o direito de pedir a modificação de seu prenome $^{159}$. Ora, além do dispositivo dar margem para que os pais adotantes modifiquem o nome da criança, dá margem para que o pequeno peça alteração de seu nome, desde que se tenha a participação processual dos pais adotantes.

Por fim, a partir de todo o exposto, nota-se mais uma lacuna não preenchida resultante do regime de incapacidades no qual as crianças e adolescentes são embarcados. Mais ainda, nota-se com clareza uma situação na qual os filhos são submetidos por completo aos desejos dos pais, mesmo em se tratando de uma questão tão pessoal e personalíssima. A necessidade de representação ou até mesmo assistência processual no caso em comento, é entendida como um verdadeiro paradoxo e acaba por limitar a efetividade do princípio do melhor interesse da criança, atingindo uma de suas esferas mais íntima.

\subsection{Direito a privacidade: confidencialidade existente na relação entre o médico e o paciente adolescente.}

De acordo com o ECA em seu artigo $2^{160}$, os adolescentes são aqueles compreendidos entre doze e dezoito anos de idade. Entretanto, a Organização Mundial da Saúde (OMS) determina que a adolescência está compreendida entre

\footnotetext{
${ }^{159}$ Artigo 47, parágrafo 5 do Estatuto da Criança e do Adolescente: “A sentença conferirá ao adotado o nome do adotante e, a pedido de qualquer deles, poderá determinar a modificação do prenome".

${ }^{160}$ Artigo 2 do Estatuto da Criança e do Adolescente: "Considera-se criança, para os efeitos desta Lei, a pessoa até doze anos de idade incompletos, e adolescente aquela entre doze e dezoito anos de idade".
} 
os dez e dezenove anos ${ }^{161}$. Independentemente dos limites etários para que se encaixe o período da adolescência, certo é que esta fase é repleta de transformações tanto físicas, como mentais e sociais.

Diante de mudanças tão profundas, os profissionais da saúde que lidam diretamente com os adolescentes devem atuar com mais cautela, respeitando essas peculiaridades. Sobre esse processo de transformação denso que sofre os adolescentes, destaca-se:

$\mathrm{O}$ adolescente tido como normal apresenta as seguintes características: a busca de si mesmo e da identidade adulta, na separação progressiva dos pais; tendência a viver em grupo e a desenvolver o pensamento abstrato; necessidade de intelectualizar e fantasiar; evolução da sexualidade e, ao mesmo tempo, a emergência de crises com base metafísica (religiosas ou ideológicas); vivência temporal singular, com atitude social reivindicatória, além das constantes flutuações de humor e manifestações contraditórias de conduta. ${ }^{162}$

Observa-se, portanto, um processo de amadurecimento do adolescente voltado para a conquista e reconhecimento de sua autonomia. Com a aproximação dessa autonomia, se reconhece mais facilmente o direito à privacidade, restringindo o acesso de terceiros no íntimo do indivíduo.

Diante disso, a confidencialidade na relação médico-paciente começa a aparecer na vida do indivíduo. Inclusive, é a partir da garantia desse sigilo que muitos adolescentes passam a se abrir e, assim, garantem um acompanhamento médico mais saudável. Nessa fase de descobertas tanto sexuais como do próprio corpo, é comum que os adolescentes não se abram completamente com seus pais, guardando para si diversas dúvidas e acontecimentos. Ao se garantir a promessa referente ao sigilo, tais questionamentos podem ser respondidos por profissionais habilitados em quem os jovens depositem confiança, garantindo assim um desenvolvimento mais sadio para os infantes.

Entretanto, para que essa relação de confidencialidade entre médico e paciente deva ser assegurada, os profissionais devem se atentar ao grau de

\footnotetext{
${ }^{161}$ Disponível em <http://www.scielo.br/scielo.php?script=sci_arttext\&pid=S0104-42302000000400024> Acessado em 28 de maio de 2018.

${ }^{162}$ SANTOS, Maria de Fátima Oliveira dos; SANTOS, Thalita Esther Oliveira dos; SANTOS, Ana Laís Oliveira dos. A confidencialidade médica na relação com o paciente adolescente: uma visão teórica. Revista Bioética, n. 20, 2012. p. 320.
} 
compreensão e maturidade do adolescente. Ultrapassada esta análise, verifica-se o gozo pleno dos direitos dos adolescentes à privacidade, confidencialidade e informação. ${ }^{163}$

Essa tão importante confidencialidade só deve ser quebrada diante de um risco grave, como por exemplo, um risco a saúde do próprio adolescente ou de outra pessoa. No entanto, importante que se ressalte que antes mesmo de entrar em contato com os respectivos pais do menor de idade, o adolescente deve ser avisado e informado deste ato pelo profissional que o acompanha ${ }^{164}$.

Posto isso, entende-se e se reconhece através da relação médico-paciente uma conquista de considerável autonomia por parte dos adolescentes tanto em relação aos próprios corpos como em relação a certas escolhas relacionadas a si. Essa questão inclusive já foi tratada no Capítulo 1 deste estudo, ao mencionar o famoso caso Gillik x Norfolk, o qual teve como desfecho a garantia dos jovens em terem sua intimidade resguardada nas relações que envolvem os médicos, principalmente no que tange a vida sexual.

As questões que envolvem saúde e os próprios corpos dos adolescentes são de caráter extremamente personalíssimo, e, por mais que seus pais se preocupem e queiram se manter informados, a depender do discernimento do adolescente, este já pode garantir seu desenvolvimento saudável lidando diretamente com seu médico.

Diante do exposto, confronta-se tal afirmação com o regime de incapacidades que abarca os adolescentes, ainda que, em alguns casos, relativamente. Questiona-se como há observância de certa autonomia diante da não mutação do mencionado regime e sua consequente imposição de representação ou assistência. A partir disso, pode-se concluir que tratando-se de um bem jurídico personalíssimo e maior, o instituto das incapacidades pode ser mitigado, afastando por ora a representatividade ou a assistência no caso em comento.

\footnotetext{
${ }^{163}$ Ibid. p. 321.

${ }^{164}$ Idem.
} 
Neste passo, chega-se a dizer que a representatividade é de maior importância quando se está diante de relações negociais e, não diante de relações que envolvem direitos da personalidade, tal qual a intimidade, por exemplo.

Ao contrário do que observamos com a questão do direito ao nome, a autonomia do adolescente é respeitada em larga medida na relação médicopaciente, consagrando o direito a privacidade que é um dos pilares dos direitos da personalidade. Esta autonomia e consequente confidencialidade, no entanto, só deve ser rompida diante de grave risco ao indivíduo ou a outrem, cabendo, nesse caso, interferência dos responsáveis do menor. 


\section{CONCLUSÃO}

\section{Uma das armadilhas da infância é que não é preciso se entender para sentir. Quando a razão é capaz de entender o ocorrido, As feridas do coração já foram profundas demais. Carlos Ruiz Zafón.}

Não obstante as louváveis intenções e conquistas legislativas em prol das crianças e dos adolescentes, nota-se, com clareza, a presença de diversas lacunas quando se analisa casos em concreto, como pode-se perceber ao longo do presente estudo. A resposta trazida para os vazios deixados, ou seja, o sistema de incapacidades cumulado com os princípios protecionistas, apresentam-se como uma alternativa simplória e ineficiente que, a cada vez mais, gera paradoxos ao invés de trazer soluções eficazes.

Imputar aos menores de idade um sistema altamente protetor, anulando quase que por completo sua autonomia, gera danos incalculáveis, sobretudo no que tange o íntimo do indivíduo.

Com o avanço do estudo do direito e a mudança de foco de sua proteção, ou seja, com a tutela voltada ao ser e não à propriedade exclusivamente, a proposta de proteção atual às crianças e aos adolescentes mostra-se ultrapassada. Assim o é, justamente pelas situações conflitantes que surgem e a ausência de respostas capazes de garantir de fato o melhor interesse da criança.

Afastar de plano a autonomia dos pequenos não é uma solução que possa ser considerada útil ou eficiente. Entretanto, afastar igualmente o sistema de incapacidades não trará resultados seguros e infalíveis.

Deste modo, o presente trabalho não propõe uma solução concreta a todo esse sistema complexo, e, sim, propõe uma nova discussão, uma reanálise do sistema protetor dos infantes afim de que ocorram modificações capazes de satisfazer os anseios e necessidades dos que irão ser o futuro do mundo. 
É bem verdade, que o processo de constitucionalização da família brasileira e, seu consequente impulso em tornar o meio familiar mais democrático, trouxe esperança e um novo olhar para os pequenos. A voz, liberdade e autonomia, ainda que expressas de maneira modesta, acabam por ganhar mais espaço e, dirimir certos danos evitáveis.

Contudo, necessita-se cautela ao atribuir liberdade de escolha às crianças e aos adolescentes, pois, embora seja defendido que os mesmos não são ausentes de completo discernimento como o sistema jurídico brasileiro nos faz crer, é inegável que a ausência de vivência pela tenra idade é geradora de uma imaturidade evidente. Como efeito, afastar o poder familiar não parece minimamente cauteloso, ao contrário.

Ademais, não parece válido distanciar o Estado dessa relação, pois, como estudado ao longo do segundo Capítulo deste trabalho, a força estatal apesar de se mostrar excessiva em alguns momentos, é capaz de garantir ao menor de idade direitos fundamentais, tal como o convívio familiar, por exemplo ou até mesmo garantir o exercício da autonomia de um infante a depender do caso em concreto.

Conclui-se portanto, que não existem saídas certas e totalmente objetivas às questões aqui propostas; não há como atribuir autonomia plena aos indivíduos que encontram-se em plena fase de desenvolvimento e formação, como não há, de igual maneira, possibilidade de afastar o direito de escolha e a liberdade de seres humanos dotados de certo grau de discernimento.

Afinal, "o processo de desenvolvimento ocorre à proporção que há o aperfeiçoamento das habilidades e competências, através da obtenção de novas capacidades adquiridas no tempo e no ritmo de cada criança, dependendo de influências internas e externas"165.

Posto isso, a saída mais sensata a problemática apontada é, sem dúvidas, o estudo detalhado do caso em questão, levando-se em consideração principalmente o discernimento da criança e do adolescente no momento exato

\footnotetext{
${ }^{165}$ PAULA, Bruna Souza; CAÚLA, Bleine Queiroz. Autonomia da Vontade da Criança sob a ótica dos direitos fundamentais - o direito ao livre desenvolvimento da personalidade. Disponível em <http://www.publicadireito.com.br/artigos/?cod=29d74915e1b32367>. Acesso em 20 de maio de 2018.
} 
do conflito. Para tanto, o auxílio de outras ciências mostra-se indispensável, eis que como estudado no Capítulo 3, o que é inadiável ou irreversível para um, não necessariamente é para o outro.

Logo, as decisões heterônomas na vida de cada criança ou adolescente podem alcançar impactos distintos e, é a partir desses impactos que as soluções devem começar a serem delineadas de forma mais segura e cautelosa, abrangendo todas as peculiaridades dos indivíduos em questão, sobretudo seu discernimento para tomar suas próprias decisões. 


\section{BIBLIOGRAFIA}

\section{Livros:}

ALBERNAZ JÚNIOR, Victor Hugo.; FERREIRA, Paulo Roberto Vaz. Convenção sobre os direitos das crianças. São Paulo: Malheiros, 2011.

ALBERTON, Maria Silveira. Violação da Infância. Crimes abomináveis: humilham, machucam torturam e matam!. São Paulo: AGE Ltda, 2005, 230 p.

BODIN DE MORAES, Maria Celina. A família democrática. In: Na medida da pessoa humana: estudos de direito civil-constitucional. Rio de Janeiro: Renovar, 2010.

COUTO E SILVA, Clóvis do. A obrigação como processo. São Paulo: Bushatsky, 1976.

DINIZ, Maria Helena. Curso de Direito Civil Brasileiro, v. 1: Teoria Geral de Direito Civil, 22 ed. São Paulo: Saraiva, 2005.

Maria Helena. Curso de Direito Civil Brasileiro: teoria das obrigações contratuais e extracontratuais. 27 ed. São Paulo: Saraiva, 2011.

,. Maria Helena. Curso de Direito Civil Brasileiro: Teoria Geral do Direito Civil. 21. ed. rev., aum. e atual de acordo com o novo Código Civil. São Paulo: Saraiva, 2004.

FACHIN. Luiz Edson. Elementos críticos do direito de família. Rio de Janeiro: Renovar, 1999. 
FREIRE NETO, João Francisco. Princípios Fundamentais do Estatuto da Criança e do Adolescente. Rio de Janeiro: Renovar, 2007.

GIDDENS, Anthony. A Terceira via: reflexões sobre o impasse político atual e o futuro da social democracia. Tradução: Maria Luiza X. de A. Borges. Rio de Janeiro: Record, 1999.

GOMES, Orlando. Direito de família. Rio de Janeiro: Forense, 1996.

JESUS. Maurício Neves. Adolescente em conflito com a lei: prevenção $e$ proteção integral. Campinas: Savanda, 2006.

LIBERATI, Wilson Donizeti. Adolescência e ato infracional - Medida socioeducativa e pena?; São Paulo: Juarez de Oliveira, 2002.

LOUREIRO, Luiz Guilherme. Teoria geral dos contratos no novo código civil. Ed. Método, 2002.

MADALENO, Rolf. Curso de Direito de Família. $6^{\text {a }}$ ed. ver., atual e ampl. - Rio de Janeiro: Forense, 2015.

MATOS, Ana Carla Harmatiuk. União entre pessoas do mesmo sexo: aspectos jurídicos e sociais. Belo Horizonte: Del Rey, 2004.

MULTEDO, Renata Vilela. Liberdade e família : Limites para intervenção do Estado nas relações conjugais e parentais. Rio de Janeiro: Processo, 2017.

NERY JUNIOR, Nelson. Código Civil comentado. 11 ed. rev., ampl. e atual. São Paulo: Editora Revista dos Tribunais, 2014. 
NETO. Luísa. $O$ direito fundamental à disposição sobre o próprio corpo: a relevância da vontade na configuração do seu regime. Coimbra: Coimbra Editora. 2004.

NEVES, José Roberto de Castro. Direito das Obrigações. Rio de Janeiro: GZ Editora, 2008, 482 p.

PEREIRA, Tânia da Silva. Direito da Criança e do Adolescente: uma proposta interdisciplinar. 2 ed. rev e atual. Rio de Janeiro: Renovar, 2008.

PEREIRA. Caio Mário da Silva. Instituições do direito civil. 26 ed - Rio de Janeiro: Forense, 2013.

PERLINGIEREI, Pietro. O direito civil na legalidade constitucional. Rio de Janeiro: Renovar, 2008.

Pietro. Perfis de direito civil. 3 ed. Traduzido por Maria Cristina de Cicco. Rio de Janeiro: Renovar, 2007.

SARLET, Ingo Wolfgang. A eficácia dos direitos fundamentais. 5 ed. Porto Alegre: Livraria do Advogado, 2005.

, Ingo Wolfgang. A eficácia dos direitos fundamentais. 9 ed. rev., atual e ampl. Porto Alegre: Livraria do Advogado, 2007.

TARTUCE, Flávio. Direito civil, v. 5: Direito de Família/Flávio Tartuce. - 12 ed.rev., atual e ampl. - Rio de Janeiro: Forense, 2017.

, Flavio. Manual de direito civil: volume único. 7 ed. rev., atual e ampl. - Rio de Janeiro: Forense, São Paulo: METODO, 2017. 
TAVARES, José de Farias. Direito da Infância e da Juventude. Belo Horizonte: Del Rey, 2001.

TEIXEIRA, Ana Carolina Brochado. Família, guarda e autoridade parental. Rio de Janeiro: Renovar, 2005.

TEPEDINO, Gustavo (Org.). Direito civil contemporâneo: novos problemas à luz da legalidade constitucional. São Paulo: Atlas, 2008.

VENOSA, Silvio de Salvo. Direito Civil: parte geral. Volume 1, 5 ed., São Paulo: Atlas, 2005.

VERONESE, Josiane Rose Petry. Temas de Direito da Criança e do Adolescente. São Paulo: LTr, 1997.

VILLELA, João Baptista. O caráter consensual da emancipação nas siete Partidas: um convite à reflexão. separata de: Faculdade de Direito da Universidade de Lisboa. Estudos em Honra de Ruy de Albuquerque. [S.1.]: Lisboa: Coimbra editora, 2006.

\section{Teses e Artigos:}

ALMEIDA, Álvaro Henrique Teixeira de. Apontamentos sobre a teoria da imprevisão, in Ciência Jurídica, ano XIV, volume 93, (maio/junho de 2000), RCJ Edições Jurídicas.

AZAMBUJA, Maria Regina Fay de. Violência sexual intrafamiliar: é possível proteger a Criança?; Revista Virtual de Textos e Contextos. São Paulo: vol. 01, n. 05, nov., 2006. 
BARROS, Nívea Valença. Violência intrafamiliar contra a criança $e$ adolescente. Trajetória histórica, políticas, sociais, práticas e proteção social. 2005. 248 p. Tese de Doutorado. Departamento de Psicologia, Pontifícia Universidade Católica do Rio de Janeiro. Rio de Janeiro, 2005.

BRUNOL, Miguel Cillero. O interesse superior da criança no marco da Convenção Internacional sobre os Direitos da Criança. In: (Org.) Méndez, Emílio Garcia.; Beloff, Mary Infância, lei e democracia na América Latina: análise crítica do panorama legislativo no marco da Convenção Internacional Sobre os Direitos da Criança. Trad. Eliete Avila Wolff. Blumenal: Edifurb, 2001.

CABRAL, Érico de Pina. A 'autonomia” no direito privado, Revista de Direito Privado, v.19, Ano 5 (julho-setembro de 2004). (Org) Nelson Nery Júnior e Rosa Maria de Andrade Nery, Ed. Revista dos Tribunais.

CORRÊA, Mariza. Repensando a família patriarcal brasileira. In: ALMEIDA, Angela (Org). Colcha de retalhos: estudos sobre a família no Brasil. São Paulo: Brasiliense, 1982.

GONÇALVES, Camila Figueiredo Oliveria; FILHO, Eginaldo de Oliveira Silva. A autonomia da criança e do adolescente e autoridade parental: entre o cuidado e o dever de emancipação. Fortaleza. 18 p. Artigo Jurídico (Pós Graduação em Direito Constitucional) - Universidade de Fortaleza.

JÚNIOR, Ecio Perin. In: O Novo Código Civil Discutido por Juristas Brasileiros, (Org) Aparecido Hernani Ferreira, Ed: Bookseller, 2003.

MACHADO, Diego Carvalho. Capacidade de agir e situações subjetivas existenciais: o exercício de situações existenciais pela pessoa adolescente a 
partir de um regime jurídico não codificado. Revista trimestral de direito civil, v. 46, p. 3-51, abril/julho de 2011.

MARTINS, Rosa. Responsabilidades parentais no século XXI: a tensão entre o direito de participação da criança e a função educativa dos pais. In: (Orgs.) PEREIRA, Tânia da Silva; OLIVEIRA, Guilherme de. Cuidado e Vulnerabilidade. São Paulo: Atlas, 2009, p. 86-87.

NERY JÚNIOR, Nelson; MACHADO, Martha de Toledo. O Estatuto da Criança e do Adolescente e o Novo Código Civil à luz da Constituição Federal: Princípio da Especialidade e Direito Intertemporal. Revista de Direito Privado, São Paulo, v.3, n.12, p 9-49, 2002.

SANTOS, Maria de Fátima Oliveira dos; SANTOS, Thalita Esther Oliveira dos; SANTOS, Ana Laís Oliveira dos. A confidencialidade médica na relação com o paciente adolescente: uma visão teórica. Revista Bioética, n. 20, 2012.

SÊCO, Thaís. A autonomia da criança e do adolescente e suas fronteiras: capacidade, família e direitos da personalidade. 2013. Dissertação (Mestrado em Direito) - Universidade do Estado do Rio de Janeiro, Rio de Janeiro, 2013. STANCIOLI, Brunello Souza. Sobre a capacidade de fato da criança e do adolescente: sua gênese e desenvolvimento na família. Porto Alegre: Revista Brasileira de Direito de Família, p. 37-42, nº 2, jul-ago-set, 1999.

TEIXEIRA, Ana Carolina Brochado. Autonomia Privada da Criança e do Adolescente: uma Reflexão sobre o Regime das Incapacidades. In: Revista Brasileira de Direito das Famílias e Sucessões. Belo Horizonte: Magister, 2007. p. 59-73. 
Ana Carolina Brochado. Direito de visitas dos avós. Revista Trimestral de Direito Civil. Rio de Janeiro, v. 10, p. 62-64, 2002.

TEPEDINO, Gustavo. A disciplina da guarda e a autoridade parental na ordem civil-constitucional. Revista Trimestral de Direito Civil, v. 17, n. 5.

Gustavo. A tutela constitucional da criança e do adolescente. In: Temas de direito civil. Rio de Janeiro: Renovar, 2009, p. 211-212, tomo 3. VIEIRA, lacyr de Aguilar. A autonomia da vontade no Código Civil Brasileiro e no Código de Defesa do Consumidor, Revista dos Tribunais, ano 90, v.791 (setembro de 2001), Ed. RT. JÚNIOR, (Org.) Otávio Luiz Rodrigues. A doutrina do terceiro cúmplice: autonomia da vontade, o princípio 'res inter alios acta', função social do contrato e a interferência alheia na execução dos negócios jurídicos, In Revista dos Tribunais, ano 93, v.821, março de 2004, Ed. RT.

\section{Sites:}

<http://www.scielo.br/scielo.php?script=sci_arttext\&pid=S010442302000000400024> Acessado em 28 de maio de 2018.

<https://forum.outerspace.com.br/index.php?threads/top-30-nomes-bizarros-járegistrados-em-cartórios-no-brasil.454543/> Acessado em 27 de maio de 2018.

Constituição dos Estados Unidos do Brasil (10 de novembro de 1937). Disponível em <http://www.planalto.gov.br/ccivil_03/constituicao/constituicao37.htm?TSPD_1 01_R0=6f7ebc2023bc7ef04a43da1e54bb7a5adA2000000000000000064417abdf fff00000000000000000000000000005b11aa2900ae2df58b >. Acessado em 24 de abril de 2018 . 
Decreto

99.710 .

Disponível

em

<http://www.planalto.gov.br/ccivil_03/decreto/1990-1994/d99710.htm>.

Acessado em 30.04.2018.

Decreto Lei $\quad \mathrm{n}^{\mathrm{o}} \quad 3.689$. Disponível em

<http://www.planalto.gov.br/ccivil_03/decreto-lei/Del3689Compilado.htm>.

Acessado em 30 de abril de 2018.

Decreto Lei $\quad \mathrm{n}^{\mathrm{o}} \quad 5.452$. Disponível em <http://www.planalto.gov.br/ccivil_03/decreto-lei/Del5452.htm>. Acessado em 30 de abril de 2018 .

Enunciado $\mathrm{n}^{\mathrm{o}} 605$ da VII jornada de direito civil. Disponível em < http://www.cjf.jus.br/enunciados/enunciado/838> Acessado em 26 de abril de 2018 .

Enunciado $\mathrm{n}^{\mathrm{o}} 607$ da VII jornada de direito civil. Disponível em < http://www.cjf.jus.br/enunciados/enunciado/843>. Acessado em 26 de abril de 2018.

Gillick $x$ West Norfolk \& Wisbeck Area Health Authority (1986). Disponível em <www.bailii.org>. Acessado em 23 de março de 2018.

JUNQUEIRA, Alice. Estatuto da Juventude: o jovem como sujeito de direitos!. Disponível em <http://pagina22.com.br/2013/08/12/estatuto-da-juventude-ojovem-como-sujeito-de-direitos/>. Acessado em 20 de abril de 2018.

KINGLSEY X KINGLSEY. Disponível em <https://en.wikipedia.org/wiki/Gregory_Kingsley>. Acessado em 20 de abril de 2018. 
Lei

6.015 .

Disponível

em

<http://www.planalto.gov.br/ccivil_03/leis/L6015compilada.htm>. Acessado em 27 de maio de 2018 .

Lei $\quad \mathrm{n}^{\mathrm{o}} \quad 5.869$. Disponível em http://www.planalto.gov.br/ccivil_03/LEIS/L5869.htm>. Acessado em 25 de abril de 2018.

Lei $\quad \mathrm{n}^{\mathrm{o}} \quad 10.406 . \quad$ Disponível em <http://www.planalto.gov.br/ccivil_03/Leis/2002/110406.htm>. Acessado em 2 de maio de 2018.

Lei no 11.698. Disponível em <http://www.planalto.gov.br/ccivil_03/_ato20072010/2008/lei/111698.htm>. Acessado em 26 de abril de 2018.

Lei $\quad \mathrm{n}^{\mathrm{o}} \quad 12.852 / 2013$. $\quad$ Disponível em <http://www.planalto.gov.br/ccivil_03/_ato20112014/2013/lei/112852.htm?TSPD_101_R0=d1d80b7c2d8397f3fb3d224c067b908 dxRR000000000000000064417abdffff00000000000000000000000000005b11a7 c200d8cbb874>. Acessado em 22 de abril de 2018.

Lei n ${ }^{o}$ 13.058. Disponível em <http://www.planalto.gov.br/ccivil_03/_ato20112014/2014/lei/113058.htm>. Acessado em 26 de abril de 2018.

Lei $\quad \mathrm{n}^{\mathrm{o}} \quad 3.017 . \quad$ Disponível em <http://www.planalto.gov.br/ccivil_03/Leis/L3071.htm>. Acessado em 2 de maio de 2018. 
$\begin{array}{lllll}\text { Lei } & \mathrm{n}^{\circ} & 8.069 & \text { Disponível }\end{array}$ <http://www.planalto.gov.br/ccivil_03/leis/L8069Compilado.htm>. Acessado em 25 de abril de 2018.

MELO, Edson Ulisses de. Sociedade mais punitiva colherá mais violência. Disponível em <https://www.conjur.com.br/2014-mar-27/edson-melo-sociedadepunitiva-colhera-violencia>Acessado em 22 de abril de 2018.

NETO, Edgard Audomar Marx. Exercício dos direitos da personalidade por criança e adolescentes: entre o exercício exclusivo e regime de incapacidade. Disponível em <https://revistajuridica.presidencia.gov.br/index.php/saj/article/viewFile/152/145 >. Acessado em 16 de maio de 2018.

NUNES. Lydia Neves Bastos Telles. Respeito aos direitos da personalidade das $\begin{array}{llll}\text { crianças } & e & \text { adolescentes. } & \text { Disponível }\end{array}$ $<$ https://periodicos.fclar.unesp.br/seguranca/article/view/5027>. Acessado em 15 de maio de 2018.

PAULA, Bruna Souza; CAÚLA, Bleine Queiroz. Autonomia da Vontade da Criança sob a ótica dos direitos fundamentais - o direito ao livre desenvolvimento da personalidade. Disponível em <http://www.publicadireito.com.br/artigos/?cod=29d74915e1b32367>. Acesso em 20 de maio de 2018.

PAULA, Bruna Souza; CAÚlA, Bleine Queiroz. Autonomia da Vontade da Criança sob a ótica dos direitos fundamentais - o direito ao livre desenvolvimento da personalidade. Disponível em <http://www.publicadireito.com.br/artigos/?cod=29d74915e1b32367>. Acesso em 20 de maio de 2018. 
SÊCO, Thaís. Por uma nova hermenêutica do direito da criança e do adolescente. Civilistica.com. Rio de Janeiro, a. 3, n. 2, jul. - dez./2014. Disponível em: http://civilistica.com/por-uma-nova-hermeneutica-do-direito-dacriança-e-do-adolescente/> Acessado em 23.03.2018.

VILLELA, João Baptista. $O$ fim das menoridades. Disponível em <youtube.com>, acesso em 19 de abril de 2018.

\section{Julgados:}

Tribunal de Justiça do Distrito Federal. Apelação n. 20150111385846. Relator: Desembargador José Divino, Sexta Turma Cível, Brasília, Julgamento: 08/03/2017.

Tribunal de Justiça do Estado do Rio de Janeiro. Apelação n. 002379697.2014.8.19.0204. Relatora: Desembargadora Mônica Maria Costa Di Piero, Oitava Câmara Cível, Rio de Janeiro, Julgamento: 10/04/2018.

Tribunal de Justiça do Estado do Rio Grande do Sul. Agravo de Instrumento $\mathrm{N}^{\circ}$ 70066315938, Relator: Desembargador Ricardo Moreira Lins Pastl, Oitava Câmara Cível, Porto Alegre, Julgamento: 12/11/2015.

Tribunal de Justiça do Estado do Rio Grande do Sul. Apelação n. 70073059586. Relator: Desembargador Luiz Felipe Brasil Santos, Oitava Câmara Cível, Rio de Janeiro, Julgamento: 23/08/2017. 